\title{
ECCLESIASTICAL ADVICE LITERATURE IN ANGLO-SAXON ENGLAND
}

\author{
A Dissertation \\ presented to \\ the Faculty of the Graduate School \\ at the University of Missouri \\ In Partial Fulfillment \\ of the Requirements for the Degree \\ Doctor of Philosophy
}

by

TOBY R. BEENY

Dr. Johanna Kramer, Dissertation Supervisor

JULY 2017 
The undersigned, appointed by the dean of the Graduate School, have examined the dissertation entitled

ECCLESIASTICAL ADVICE LITERATURE IN ANGLO-SAXON ENGLAND presented by Toby R. Beeny, a candidate for the degree of doctor of philosophy, and hereby certify that, in their opinion, it is worthy of acceptance.

Professor Johanna Kramer

Professor Emma Lipton

Professor Lee Manion

Professor Dennis Trout 
for Kat,

Octavius, Leonidas, and Edward 


\section{ACKNOWLEDGMENTS}

I am grateful to the many people who have offered their advice and support throughout my academic journey. First, I will remain forever grateful to my advisor and mentor, Professor Johanna Kramer, who has generously given over so much of her time and energy in guiding my work. Not only has she carefully read and commented on repeated drafts of my dissertation, but has also offered endless support in my professional development, in looking over conference papers, job materials and other such matters. I am also thankful for my other committee members, who have all advised me and improved my work in various ways. Professor Emma Lipton's courses in Middle English have improved my understanding of the larger medieval world, and her feedback on my work has made me a better writer. She also suggested that I read Judith Ferster's work, which provided a spark for my dissertation project. Professor Dennis Trout asked tough questions during my comprehensive exams that have helped me to better frame my dissertation. He also came to my aid in translating some especially thorny Latin. Professor Lee Manion, despite being a late addition to my committee, has offered gracious support and advice at every turn. I am also grateful to the late Professor John Foley, who served on my committee before his passing. Although he never read my dissertation, his personal advice and his scholarship have shaped my own work.

I am grateful for the advice and support of Professor Eric Bryan, whose course on Tolkien at the University of Missouri-Saint Louis finalized my decision to be an AngloSaxonist, and who introduced me to historical pragmatics, which has since become a key aspect of my critical approach. I am also grateful for his support in reading my materials 
when first applying to $\mathrm{PhD}$ programs, in offering feedback on my writing, and for many good conversations at Kalamazoo. Professor Matt Gordon taught me the basics of historical linguistics and linguistic methodology, and helpfully served on my comprehensive exam. Professor Signe Cohen also served on my comprehensive exam, and her Old Norse class has been very helpful in thinking about the pan-Germanic medieval north. Professor Frank Grady at the University of Missouri-Saint Louis kindled my passion for Arthurian literature, and was a generous advisor during the early stages of my career. Professor Brian O'Camb at Indiana University Northwest offered me helpful advice for navigating the publishing world and job market.

Other faculty members at the University of Missouri have been very supportive as well. Professor Sam Cohen, as DGS and afterwords, has been very helpful in navigating the academic world of conferences, job markets, and professional documents. Professor Alexandra Socarides and Professor Anne Myers, who each served as Literature Coordinator, have both improved my teaching through classroom observations and valuable feedback. Professor Carsten Strathausen taught me to not hate theory, and introduced me to Hans-Georg Gadamer, whose writings has shaped my understanding of how we as medievalists approach and interpret the past. Professor Mark Smith's challenging class on Latin paleography helped me to understand how to work with manuscripts.

I have also benefited from the companionship of fellow graduate students at the University of Missouri: Peter Ramey, Derek Updegraff, Rebecca Mouser, Megan Woosley, J.D. Smith, Drew Darr, Ryan Habermeyer, Eric Scott, Colin Beineke, and Nicole Songstad. 
I am thankful for Joshua Koester and Adam Borrego, two close personal friends who always gave me encouragement during this long journey, and who helped me keep my sanity when I needed to take a break from research.

Most of all I am grateful to the infinite patience and encouragement of my wife, Kat. She always pushed me when I felt like giving up, and always supported my work in every way. My wonderful children—Octavius, Leonidas, and Edward—have also been a great source of encouragement (and distraction). I know it wasn't easy to see dad spend so many summer days typing on his laptop rather than going fishing or swimming. My family is the source of my greatest strength, and without them my academic labor would be meaningless. 
TABLE OF CONTENTS

ACKNOWLEDGMENTS.................................................. ii

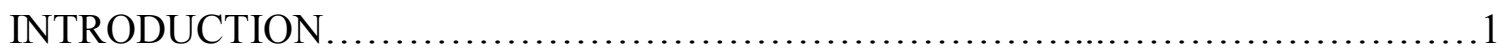

Chapters:

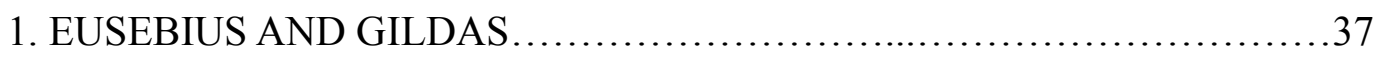

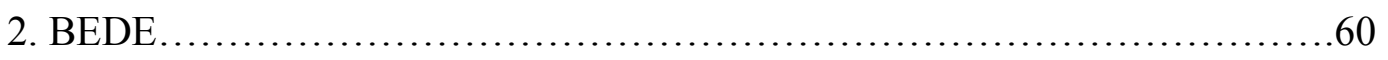

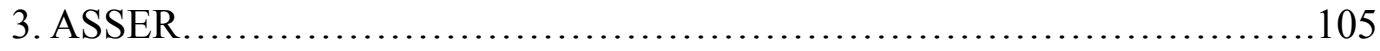

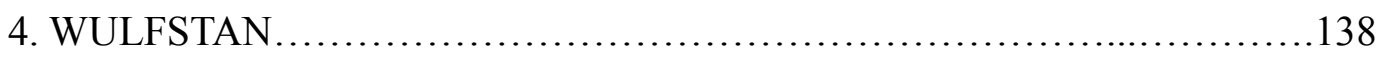

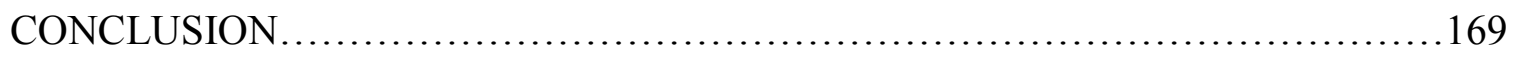

APPENDIX I: IMAGES FROM THE STUTTGART PSALTER ......................174

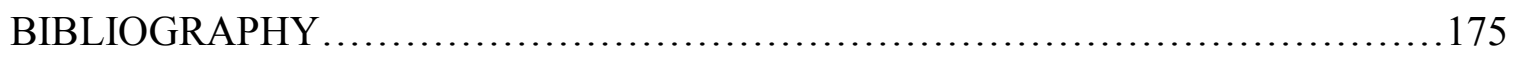

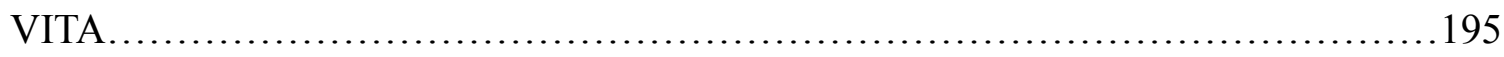




\title{
INTRODUCTION
}

\author{
"In human affairs no art, as they say, is more difficult than to rule well amidst the stormy \\ tempests of this turbulent world and to govern the state wisely. And this art attains its \\ highest degree of perfection when the state itself has prudent and superlative \\ counselors." \\ Sedulius Scottus, On Christian Rulers ${ }^{1}$
}

This is a work concerned with kings, and those who advised them. More specifically, it examines the way that ecclesiastical figures during the Anglo-Saxon period (c. 410-1066) used political rhetoric within religious works to effect political change, especially the ways in which these writers shaped the duties and roles of kings. Despite prohibitions against ecclesiastics becoming involved in politics, monks and especially bishops were often intensely involved in governance during the Anglo-Saxon period. In addition, they held a virtual monopoly over literacy and textual production, a force that ecclesiastics used to shape society. I argue that a number of texts produced by these ecclesiastics can be understood as advice literature. While there is an abundance of scholarship on advice literature during the later medieval period, it is not an area that has been given serious critical attention among Anglo-Saxonists. ${ }^{2}$

${ }^{1}$ Oliver O'Donovan and Joan Lockwood O'Donovan, eds. From Irenaeus to Grotius: A Sourcebook in Christian Political Thought, 100-1625 (Grand Rapids, Mich.: William B. Eerdmans Pub., 1999), 221.

${ }^{2}$ Some recent work on medieval advice literature includes: Sverre Bagge, The Political Thought of the King's Mirror (Odense: Odense University Press, 1987); István P. Bejczy, and Cary J. Nederman, eds., Princely Virtues in the Middle Ages, 1200-1500 (Turnhout: Brepols, 2007); Charles F. Briggs, "Scholarly and Intellectual Authority in Late Medieval European Mirrors." In Global Medieval: Mirrors for Princes Reconsidered, edited by Regula Forster and Neguin Yavari, 26-41. (Boston, Massachusetts: Ilex Foundation, 2015); Matthew Giancarlo, "Mirror, Mirror: Princely Hermeneutics, Practical Constitutionalism, and the Genres of the English Fürstenspiegel." Exemplaria 27, no. 1-2 (May 1, 2015): 35-54; Libby Karlinger Escobedo, The Milemete Treatise and Companion Secretum Secretorum: Iconography, Audience, and Patronage in Fourteenth-Century England (Lewiston, N.Y: Edwin Mellen Press, 2011); Judith Ferster, Fictions of Advice: The Literature and Politics of Counsel in Late Medieval England (Philadelphia: University of Pennsylvania Press, 1996). 
Stated most broadly, my concern is with the ways that texts were used for political purposes during the Anglo-Saxon period, an interpretative approach that relies on a great deal of historical contextualization. At heart, I would consider my methodology to be philological, a term that embraces a range of interdisciplinary practices. As Siegfried Wenzel has noted, in addition to language, a philologist must also consider "whatever contextual information might help elucidate a text." ${ }^{3}$ This would include source texts, historical and biographical backgrounds, "socioeconomic conditions," material processes of manuscript production, religious or cultural factors, the purpose for which the text was created, "and much else." ${ }^{4}$ Wenzel then concludes:

In this wider sense, I would think of philology not so much as an academic discipline with a clearly defined object and proper methods of investigation, but rather an attitude. It is precisely what the etymology of the word declares, "love of the word": an appreciative attraction to verbal documents that seeks to understand their meaning, starting with the surface and penetrating to whatever depths are possible, but also alert to the fact that a given text comes from and is shaped by a specific time and place that usually is significantly different from that of the observer. ${ }^{5}$

I have attempted then, as far as is possible, to understand the texts I am examining within their original contexts, while remaining aware of the gap that separates us from the text's original environment. In the end, I try to always remain in close contact with the language of the text, and feed all contextual knowledge back into a greater understanding

\footnotetext{
${ }^{3}$ Wenzel, "Reflections on (New) Philology," 12.

${ }^{4}$ Wenzel, "Reflections on (New) Philology," 12.

${ }^{5}$ Wenzel, "Reflections on (New) Philology," 12.
} 
of the words or passage in question.

This approach to texts is not by any means new, but has recently been revisited by literary scholars who seek to better understand political subtext. Jonathan Wilcox's work on Wulfstan's Sermo Lupi ad Anglos uses historical and political context to demonstrate how the sermon "is deeply grounded in the specific events of its original performance at York on or about 16 February 1014." ${ }^{6}$ He notes that these political contexts have been understudied and "more can yet be uncovered" by literary scholars. ${ }^{7}$ A similar approach is employed by John Edward Damon in his work on royal advice during the reign of Æthelred II. ${ }^{8}$ His analysis sheds light on the intricacies of Æthelred's court, helping us to better understand how advice was given and received during the period, as well as the political subtext of The Battle of Maldon. Damon has performed similar work by considering the ways that military and political realities shaped who was regarded as a saint in eleventh-century Anglo-Saxon England, thus providing us with a deeper understanding of Ealdorman Byrhtnoth's motivations. ${ }^{9}$ Stephen J. Harris has also explored the politics of The Battle of Maldon, focusing on loyalty hierarchies, and has also examined the way ethnicity created political communities in early England. ${ }^{10}$ Derek

${ }^{6}$ Jonathan Wilcox, "Wulfstan's Sermo Lupi Ad Anglos as Political Performance: 16 February 1014 and Beyond." In Archbishop of York: The Proceedings of the Second Alcuin Conference, edited by Matthew Townend, 375-96. Studies in the Early Middle Ages 10. (Turnhout: Brepols, 2004), 376.

${ }^{7}$ Wilcox, "Wulfstan's Sermo Lupi Ad Anglos as Political Performance," 376.

8 John Edward Damon. "Advisors for Peace in the Reign of Æthelred Unræd.” In Peace and Negotiation: Strategies for Coexistence in the Middle Ages and the Renaissance, edited by Diane Wolfthal, 57-78. Studies in the Middle Ages and the Renaissance 4. (Turnhout: Brepols, 2000).

${ }^{9}$ John Edward Damon, "Sanctifying Anglo-Saxon Ealdormen: Lay Sainthood and the Rise of the Crusading Ideal." In Via Crucis: Essays on Early Medieval Sources and Ideas in Memory of J.E. Cross, edited by Thomas N. Hall, Thomas D. Hill, and Charles D. Wright, 185-209. Medieval European Studies 1. (Morgantown, WV: West Virginia University Press, 2002).

${ }^{10}$ Stephen J. Harris, "Oaths in The Battle of Maldon." In The Hero Recovered: Essays on Medieval Heroism in Honor of George Clark, edited by Robin Waugh and James Weldon. (Kalamazoo: Medieval Institute Publications, Western Michigan University, 2010); Idem, Race and Ethnicity in Anglo-Saxon Literature (New York: Routledge, 2003). 
Updegraff's work on Ælfric reveals "a political message of Viking resistance” embedded within his homilies. ${ }^{11}$ Other recent work of this sort includes: Rachel S. Anderson's examination of Ælfric's political concerns about kingship; Jonathan Davis-Secord's work on Wulfstan's politics within his homilies; and Alice Sheppard's research on the courts of Alfred and Æthelred. ${ }^{12}$ What connects these works and my own research is an exploration of the political subtext through historical contextualization of the work. In my case, I am particularly focused on the ways that ecclesiastic writers used the prose forms of biography, history, and homily to advance political conceptions of kingship, and how this conception of kingship changed over time.

A common element of the works I examine is the use of exempla to drive political messages. ${ }^{13}$ At its most basic, an exemplum is "a short tale used as an example to illustrate a moral point, usually in a sermon or other didactic work." ${ }^{14}$ This element can be seen, for example, when Bede gives an account of a king who wins battles and glory for his people. A writer can also use negative examples to show behavior that should be avoided. Larry Scanlon, in his consideration of exemplarity in the Chaucerian tradition, argues that the exemplum is defined:

${ }^{11}$ Derek Updegraff, "Style and Structure, Politics, and Preaching: The Lives of Saints and Other Alliterative Works by Ælfric of Eynsham.” Diss. (University of Missouri-Columbia, 2013).

${ }^{12}$ Rachel S. Anderson, “Ælfric’s Kings: Political Hagiography in Anglo-Saxon England.” Diss. (Indiana University, 2004); Jonathan Davis-Secord, "Rhetoric and Politics in Archbishop Wulfstan's Old English Homilies." Anglia 126, no. 1 (2008): 65-96; Alice Sheppard, "The King's Family: Securing the Kingdom in Asser's Vita Alfredi." Philological Quarterly 80, no. 4 (2001): 409-39; Idem, "Noble Counsel, No Counsel: Advising Ethelred the Unready." In Via Crucis: Essays on Early Medieval Sources and Ideas in Memory of J.E. Cross, edited by Thomas N. Hall, Thomas D. Hill, and Charles D. Wright, 393-422. Medieval European Studies 1. (Morgantown, WV: West Virginia University Press, 2002); Idem, Families of the King: Writing Identity in the Anglo-Saxon Chronicle (Toronto: University of Toronto Press, 2004).

${ }^{13}$ An exception to this is Wulfstan, whom I consider in Chapter 4. Wulfstan employed a much more straightforward style in his homilies.

${ }^{14}$ Chris Baldick, "exemplum." In The Oxford Dictionary of Literary Terms (Oxford University Press, 2015). http://www.oxfordreference.com/view/10.1093/acref/9780198715443.001.0001/acref9780198715443-e-429. 
by its constant movement between the historical and the textual ... The exemplum illustrates a moral because what it recounts is the enactment of that moral. The moral does not simply gloss the narrative. It establishes a form of authority, enjoining its audience to heed the lesson, and to govern their actions accordingly. It is more than an abstract principle. It would be better described as a moral law: a value which the exemplarist assumes already binds the community together ... an exemplum is a narrative enactment of cultural authority. ${ }^{15}$

The authority that the exemplum enacts within advice literature is drawn from biblical examples from the Old Testament, such as from the reigns of Saul and David, but also from native examples, by showing glorious kings from a people's past. These two cultural authorities were then often blended together, by first indicating the excellence of a native figure and then compounding the inherent authority by showing the similarity of that figure to a biblical ruler. Using exempla to persuade audiences has a long tradition among ecclesiastic writers, and was especially prominent among the mirrors-of-princes genre. ${ }^{16}$ The use of exempla by ecclesiastical writer allowed them to wield cultural authority in a didactic way while also allowing deniability through the obliqueness of the critique.

\section{Advice Literature}

The works I consider are varied in terms of form and genre. What they have in

\footnotetext{
${ }^{15}$ Larry Scanlon, Narrative, Authority, and Power: The Medieval Exemplum and the Chaucerian Tradition (Cambridge; New York: Cambridge University Press, 1994), 33-34, 82.

${ }^{16}$ Scanlon, Narrative, Authority, and Power, 58.
} 
common is a political subtext of kingship, and I refer to them collectively as advice literature. As Matthew Giancarlo has noted, advice literature has taken on various forms over time and is difficult to define; it "appears less as a genre and more a genre of genres. ${ }^{17}$ While creating sharp lines between what is and what is not advice literature is a near-impossible task, one can still observe and catalog various broad changes in these types of works over the medieval and Early Modern periods. Within Anglo-Saxon and Carolingian contexts, ecclesiastical figures were core members of the monarch's advisory council. Indeed, they were often the most important figures present. Anglo-Saxon charters list bishops and abbots above secular lords such as ealdormen, giving them a place of honor. Bede's Historia Ecclesiastica gentis Anglorum and the Anglo-Saxon Chronicles also repeatedly show ecclesiastical figures as key confidants of the king. Because these men were part of the religious profession, the advice they gave and the idea of kingship they promoted were also quite religious in nature. As Charles Briggs has argued, political writers of this period saw kingly virtues as "divinely given" rather than learned. ${ }^{18}$ As Sedulius Scottus emphasized in the ninth century, "divine counsels should be preferred over human ones, since it is more important to heed God than men." ${ }^{19}$ As I argue throughout this work, ecclesiastics tended to see the monarchy as critically interconnected with the Church, and a divinely appointed institution. Sedulius and others understood the king's primary duty to be the protection and organization of the Church:

\footnotetext{
${ }^{17}$ Giancarlo, "Mirror, Mirror," 35-36. Giancarlo provides numerous examples of advice literature, including "texts of the De regimine tradition proper in its primary Aristotelian/Aegidian and Thomistic/Ptolomaic strains; texts of the 'dicts and sayings' tradition of wisdom-literature and proverb collections; conduct literature and the literature of bodily health and physiognomy, especially the many version of the pseudo-Aristotelian Secretum Secretorum that were among the most popular texts of the Middle Ages; exempla and history .. . court literature ... legal writings." Giancarlo concludes his extensive survey by noting, "others could also be included."

${ }^{18}$ Briggs, "Scholarly and Intellectual Authority," 28.

${ }^{19}$ O'Donovan and O'Donovan, From Irenaeus to Grotius, 224, § 6.
} 
A just prince is then known to honor the Most High when he shows himself the helper and protector of those who labor in the Lord's field, as it were, the stewards of the Great King. For, it is certain that the Almighty in his kindness will graciously dispose the affairs of an earthly prince to the degree He sees that prince solicitous with regard to His affairs, namely, those of Holy Church ... such a ruler, with diligent care, should wisely plan to convene synodal assemblies two or three times every year ... in that assembly, it is proper that the prefects themselves of the churches be examined as to how they perform their ministries, or how they both instruct the people entrusted to them with divine doctrine as well as inspire them with the example of holy behavior. ${ }^{20}$

This was the view we often find during the early medieval period in Northern Europe: the king was seen foremost as a religious figure and his principal advisors were ecclesiastics, who guided him via a religious worldview. As kings during this period tended to be quite religious themselves, the situation was more-or-less stable. The obligations of kingship grew and changed focus during this period, but the essential nature of the office did not. Eusebius, Gildas, Bede, Asser, and Wulfstan all saw the king as critical to the salvation of the people they ruled. This essential understanding of the king as a religious figure was to drastically change during the late medieval and Early Modern period, and it began with the ecclesiastic writers themselves.

Starting in the twelfth and thirteenth century, advice for monarchs shifted to more practical concerns, and the those writing advice literature increasingly came from the

${ }^{20}$ O'Donovan and O'Donovan, From Irenaeus to Grotius, 225, § 11. 
secular class. During the twelfth century, ecclesiastics like John of Salisbury (1120-1180) began to think about kingship in terms of classical political ideas, focusing on the efficacy of the cardinal virtues. ${ }^{21}$ This marked a shift towards humanistic philosophy, and away from the divinely appointed gifts of the monarch. This shift towards pragmatism was catalyzed by the translation of Aristotle's Nichomachean Ethics into Latin in 1253 by Robert Grosseteste, Bishop of Lincoln. ${ }^{22}$ One of the key elements of Aristotle's ethical system is that virtue must be learned through a process of habituation. In other words, a monarch could not be born with a set of divinely inspired gifts. He had to be educated and trained so that he might rule well. This idea that the monarch could and should be educated caused a great proliferation of "mirrors for princes," which were manuals for governance directed towards kings and other princes. However, the focus of these manuals were focused on secular governance rather than sacral kingship. In the fifteenth century, writers like John Fortescue and Thomas Hoccleve saw the king as "not just ... an individual but as a self-authorizing embodiment of the basic principles of law." ${ }^{23}$ While the king was certainly still regarded as occupying a position elevated over the common people, his embodiment of law represents the king as a sort of flesh-and-blood constitution rather than a direct minister of God who embodied the gens.

\section{Anglo-Saxon Advice Literature}

Advice literature for the Anglo-Saxon period is a topic that has been largely

\footnotetext{
${ }^{21}$ Briggs, "Scholarly and Intellectual Authority," 28.

${ }^{22}$ Briggs, "Scholarly and Intellectual Authority," 28. A modern edition of this work is H. Paul F. Mercken, ed., The Greek Commentaries on the Nicomachean Ethics of Aristotle in the Latin Translation of Robert Grosseteste, Bishop of Lincoln (Leuven, Belgium: Leuven University Press, 1991).

${ }^{23}$ Giancarlo, "Mirror, Mirror," 35.
} 
ignored. This is understandable. While the later medieval period abounds in advice manuals, this form of writing seemingly does not exist in Anglo-Saxon texts. And yet, as Chris Given-Wilson has remarked, the only option besides deposing a king was to give him advice. ${ }^{24}$ The work of Judith Ferster has pointed out how, during the later medieval period, even literature not generally thought of as advice literature can be read as having political intentions. ${ }^{25}$ Many of the important writers of the period, such as Chaucer and Gower, worked close to the court (although they were not employed as poets), and would have seen firsthand many of the activities of the nobles. Any form of open criticism was out of the question, but writers of the period worked more subtly, time and again including critique in their works. In contrast to these later poets who were merely near the king, the ecclesiastical authors I wish to consider were often active forces in government, through the witan and through active law-making.

Yet, no matter how close one was to the king, criticizing him remained a dangerous proposition. The quote above by Given-Wilson, while made in reference to the late fourteenth century, holds just as true for the Anglo-Saxon period. In 956, on the day of Eadwig's coronation, the teenage king abruptly left his coronation feast to enjoy the company of two women. Archbishop Oda criticized this behavior, but no one dared to act against the king, except Abbot Dunstan, who found the king with the two women, the royal crown thrown casually upon the ground. Dunstan placed the crown back upon Eadwig's head and led him back to the banquet. For his boldness, Dunstan would have all his property confiscated. Eventually he fled the realm when he realized his life was in

\footnotetext{
${ }^{24}$ Chris Given-Wilson, The Royal Household and the King's Affinity: Service, Politics, and Finance in England, 1360-1413 (New Haven: Yale University Press, 1986), 187.

${ }^{25}$ Ferster, Fictions of Advice, $3 \mathrm{ff}$.
} 
danger too. ${ }^{26}$ Because direct action, even against a boy-king, was often disastrous to those who would offer critique, such criticism had to be displaced.

Writers during the Middle Ages often had to self-censor and displace their more critical advice out of fear of repercussions or because of self-interest. As Ferster points out, "it does not take an office of censorship to put limits on the media ... there were medieval constraints on speech and writing, not officially instituted or announced but still effective." ${ }^{27}$ There were a number of strategies that writers could use to displace criticism. One tactic was to criticize those that surrounded the king. As Ferster remarks, "Since criticizing the king was sometimes dangerous, advisors on the council as well as those who were the king's personal friends and confidants were the foci of conflict and controversy, and criticism was sometimes displaced onto them even when adult kings had control of their faculties and their governments." ${ }^{28}$ Since the ecclesiastics that I am considering were most often bishops and on the witan, this is not a tactic often employed among this group, as that criticism would hit a little too close to home. Another possible method was advice through exempla. By taking a figure, especially from the past, and either praising his merits or condemning his faults, the writer had a certain amount of deniability. This can be seen in Bede's Ecclesiastical History, in setting Edwin and Oswald upnas ideal figures of kingship. ${ }^{29}$ This creates a situation where the author is, in James C. Scott's formulation, "smuggling ... portions of the hidden transcript, suitably

\footnotetext{
${ }^{26}$ Charles G. Herbermann, Edward A. Pace, Conde B. Pallen, Thomas J. Shahan, and John J. Wynne, eds, "St. Dunstan." In The Catholic Encyclopedia: An International Work of Reference on the Constitution, Doctrine, Discipline, and History of the Catholic Church, 5:199-202. (New York: Robert Appleton Company, 1909), 199-202.

${ }^{27}$ Ferster, Fictions of Advice, 9.

${ }^{28}$ Ferster, Fictions of Advice, 2-3.

${ }^{29}$ N. J. Higham, "Bede's Agenda in Book IV of the 'Ecclesiastical History of the English People': A Tricky Matter of Advising the King." Journal of Ecclesiastical History 64, no. 3 (July 2013): 484.
} 
veiled, onto the public stage."30

Certain figures were more outspoken, however. Archbishop Oda had no fear in addressing the king directly, such as in his Chapters where he writes:

In the second chapter we admonish the king and his princes and his men who are in authority, that they be obedient with great humility to their archbishops and to all of their bishops, because those who have been given the keys to the kingdom of heaven have the strength both to bind and to loosen. And let them value not their secular power, for God resists the prideful while showing favour to the humble. And the king should have prudent councilors, fearing God above the business of the realm, so that the people, being instructed by the good example of the king and his great men, might accomplish much in the praise and the glory of God. ${ }^{31}$

Yet even here the advice is given in broad abstract statements that seemingly could apply to any monarch of any time. Oda is drawing upon the Scriptural authority of Matthew 16:19 here: "And I will give to thee the keys of the kingdom of heaven. And whatsoever thou shalt bind upon earth, it shall be bound also in heaven: and whatsoever thou shalt loose upon earth, it shall be loosed also in heaven." 32 As Trousdale remarks, "It hints ever

${ }^{30}$ James C. Scott, Domination and the Arts of Resistance: Hidden Transcripts. Revised ed. (New Haven: Yale University Press, 1992), 157

${ }^{31}$ Councils and Synods: A.D. 871-1204. Vol. 1.2 vols. (Oxford: Clarendon Press, 1981), 70: "Secundo capitulo ammonemus regem et principes et omnes, qui in potestate sunt, ut cum magna humilitate suis archiepiscopis omnibusque aliis episcopis obedient, quia illis claves regni celorum date sunt et habent poetestatem ligandi atque solvendi; nec se magni pendant in seculari potentia, quia Deus superbis resistit, humbilibus dat gratiam. Habeatque rex prudentes consiliarios, Deum timentes super regni negotia, ut populus, bonis exemplis regis et principum eruditis, proficiat in laudem et gloriam Dei." Translation Trousdale, "Being Everywhere at Once," 278.

32 "Et tibi dabo claves regni caelorum. Et quodcumque ligaveris super terram, erit ligatum et in caelis : et quodcumque solveris super terram, erit solutum et in caelis." All Bible references, both from the Latin Vulgate and Douay-Rheims translation, are from Douay-Rheims Bible Online. 
so slightly at dependency, but the emphasis remains one of cooperation between just judges, both secular and ecclesiastic." 33 Oda here is emphasizing the importance of the king working with "prudent councilors," of his listening to the advice of the bishops. Yet at the same time, Oda's advice here is abstract enough to avoid censure. The problem with such methods of displacement, as Robert Lane has pointed out, is that "strategies that would protect [the author] also risked rendering untintelligible the sensitive material that required protection in the first place" 34 Authors of advice literature did not seek to simply restate generalities, but rather hid their specific criticism within such broad statements. In the excerpt from Oda, for instance, the Archbishop is telling the king that if he does not listen to the advice of his bishops, he will lose God's favor. Why did Oda decide to write that at that time? What was his motivation? What specifically did he hope the king would do? And what model of kingship did he have in mind when he wrote such advice?

It is the purpose of this dissertation to answer these questions, to take seemingly abstract moralizing, historical narrative, and biographical accounts, and contextualize it within local political situations. Anglo-Saxon ecclesiastics were, despite being prohibited by canon law, ${ }^{35}$ intensely involved in politics and power struggles. At first these men worked hard to gain influence in royal government, then later became part of the official council. By the time of Alfred, Church and state were practically one unit, creating what

\footnotetext{
${ }^{33}$ Trousdale, "Being Everywhere at Once," 278

${ }^{34}$ Robert Lane, Shepheard's Devises: Edmund Spenser's "Shepheardes Calender" and the Institutions of Elizabethan Society (Athens: University of Georgia Press, 1993), 60.

${ }^{35}$ Trousdale, "Being Everywhere at Once," 279-80. Specifically, the tenth canon of the 786 Legantine Decrees "prohibits bishops from attending secular councils." Perhaps it is not coincidental that in the mid-ninth century Church councils met at the witan instead of separately. The witan would then no longer be considered a purely secular council since the bishops were meeting there for Church business as well.
} 
Loyn has described as "an ordered Christian society." 36 The place and position that Wulfstan was writing from is obviously different than that occupied by Bede. Through analyzing these texts from within their political contexts, we can begin to uncover the partially masked messages encoded therein.

\section{Anglo-Saxon Kingship}

In a work dealing with kings and kingship, it is important to establish precisely what I mean by these terms, and what these terms meant during the period in question. First of all, throughout this work I use the terms "king" and "monarch" interchangeably to refer to rulers, including to Emperor Constantine I. For my theoretical consideration of the institution of kingship, I am greatly indebted to the work of Francis Oakley, especially his work, Kingship: The Politics of Enchantment. As Oakley demonstrates, there is a strange modern mentality in regards to kings, in that kingship is sometimes considered this odd governmental breach that occurred between classical and modern forms of republican government. ${ }^{37}$ But historically speaking, democratic forms of government are the oddity:

In terms, that is to say, of its antiquity, its ubiquity, its wholly extraordinary staying power, the institution of kingship can lay strong claim to having been the most common form of government known, world-wide, to man. Consigned thereby to merely provincial status (world-historically speaking) are the consensual, representative, republican, and democratic forms that bulk so large on our contemporary

\footnotetext{
${ }^{36}$ Loyn, The Governance of Anglo-Saxon England, 72

${ }^{37}$ Francis Oakley, Kingship: The Politics of Enchantment (Malden, MA; Oxford: Blackwell Pub., 2006), 4
} 
political landscape, and to which those of us concerned with political philosophy and its history have tended to devote by far the greater part of our attention. ${ }^{38}$

In all societies the world over, including Anglo-Saxon society, by the time writing and history develops, kingship is already present and firmly established. Yet what sort of office is meant by the term "king," cyning, rex, or the many other terms used to describe a monarch is not always entirely clear. And despite the global ubiquity of kingship, this umbrella term captures a great number of roles.

The function and nature of kings vary greatly in different cultures and times, yet the religious element of kingship remains. Even if we restrict ourselves to Anglo-Saxon England, the nature of kingship is not a stable institution other than the idea that the office is somehow a spiritual one. As Rachel Anderson points out:

This view of kingship - that there was a mystical, quasi-religious element involved with it—has influenced much of the scholarship on the topic. From the deified emperors of Rome to the Irish kings, and even to nineteenth-century Thailand and present-day Africa, it is apparent that the idea of kingship connotes more than "the guy in charge" or the political functioning of the executive-in-chief present in many modern, industrialized societies of today. ${ }^{39}$

As will be examined more in-depth throughout this work, one must set aside modern concepts of separation of church and state and the functions of modern executives, as they have little connection to medieval (or modern) kingship. As Henry Meyers notes,

\footnotetext{
${ }^{38}$ Oakley, Kingship, 4.

${ }^{39}$ Anderson, “Ælfric’s Kings,” 30.
} 
being a king amounts to more "than simply ruling as one man ... the king must possess a certain mystique or charisma in order to fulfill his role adequately." But he goes on to state that the qualities we might expect from a modern leader were not always necessary, since the "role of embodying and symbolizing the people may actually be his main function, while major political decisions can be made by others without necessarily drawing into question the worth of the office or its holder ... Kingship, except as an art and science, is not based particularly on logic or rationality." ${ }^{, 0}$ Within Anglo-Saxon texts, we can observe a range of kings as well, from grim warlords leading their comitatus to sainted figures such as Edward the Confessor. Ecclesiastical advisors sought to direct these figures towards a vision of kingship that was transcendent and sacral while also fitting the circumstances of current politics.

The actual functions of kings varied considerably. In some cases, "kingship involved the full panoply of governing roles - administrative, military, judicial, economic, religious," while in other cases "the role was a much more limited, focused, or specialized one. ${ }^{, 41}$ Much of this variety is a product of historical context:

At one end of the spectrum, and reflecting the turbulent conditions prevailing in this or that region, the emphasis lay heavily on the king's military role as lord of hosts or leader in war ... At the other end of the spectrum, however, one encounters no difficulty in identifying a host of kingships ... to which hardly any remnant of what we today would call 'political' power attaches, though they do tend to be possessed of (or

\footnotetext{
${ }^{40}$ Henry Meyers, Medieval Kingship (Chicago: Nelson-Hall, 1982), 1.

${ }^{41}$ Oakley, Kingship, 11.
} 
burdened with) extensive ceremonial or ritual functions. ${ }^{42}$

The late Merovingian kings are a well-known example of kings who, after 687, seemingly lacked direct political force, and whose more direct functions were instead carried out by the Carolingian "mayors of the palace."43

The Anglo-Saxon period did not see any "ritual kings," like the late Merovingians, and while the institution changed over the period, we can create some broad definitions. Firstly, kings were men. With some very rare exceptions, AngloSaxons did not accept females as rulers, and "the function of a queen in the medieval period was often of a very different kind and nature than a king." 44 In fact, for much of the Anglo-Saxon period, the king's wife was given no special title or privileges at all.

Secondly, the king was expected to be a capable warleader. While this aspect became slightly relaxed during the eleventh century as kings took on new roles, it remained a central function of kingship throughout the period. ${ }^{45}$ This is the principal reason why child kings were an extreme rarity in Anglo-Saxon England. For example, King Osred of Northumbria (d. 716) represents the only known case of a Northumbrian minor ascending to the throne; that he was was murdered shortly after turning eighteen illustrates the reason why minors were usually passed over, as there was fierce

${ }^{42}$ Oakley, Kingship, 11-12.

${ }^{43}$ Oakley, Kingship, 11-12.

${ }^{44}$ Anderson, “Ælfric's Kings," 29. A notable example of an Anglo-Saxon female ruler was Æthelflæd, "Lady of the Mercians" (d. 918). Although not a queen, Æthelflæd was the eldest daughter of Alfred the Great and took charge of Mercia after her husband, Æthelred of Mercia (d. 911) fell into ill-health. After his demise, she continued to rule in her own name, under the overlordship of her father, Alfred (Maggie Bailey, "Elfwynn, Second Lady of the Mercians." In Edward the Elder 899-924, edited by N. J. Higham, 112-27. (Abingdon, UK: Routledge, 2001), 113). Æthelflæd's daughter, Ælfwynn, attempted to rule after her mother's death in 918, but, as the Anglo-Saxon Chronicles relate, she was forcibly removed from power and taken to Wessex (George Norman Garmonsway, The Anglo-Saxon Chronicle (London: Dent, 1955), [C 919], p. 105).

${ }^{45}$ H. R. Loyn, The Governance of Anglo-Saxon England, 500-1087 (Stanford: Stanford University Press, 1984), 18. 
competition for power. ${ }^{46}$ In order to succeed to the throne, a man generally needed to already be a proven warrior and to have troops at his command in order to secure his position. ${ }^{47}$ By the end of the Anglo-Saxon period, a king had gathered a number of duties to himself, but above all stood his obligation to defend his people.

Third, a would-be king had to possess royal blood. Almost all the royal AngloSaxon houses traced their decent from Woden, even after they had converted to Christianity. ${ }^{48}$ As H.R. Loyn argues:

From the seventh century forward no ruler who could not claim membership of one of the royal dynasties governed an English folk without earning for himself the opprobrium of some of his people. It was held even by the most restrained commentators as shameful that a man not of the royal kin should be elevated to the kingship. Ælle of Northumbria was bluntly described by the Anglo-Saxon Chronicler (under 867) as an ungecynde cining, a king not of the proper ruling stock. Belief in the importance of the blood royal may therefore be isolated as an early and basic characteristic of English political thought. ${ }^{49}$

Despite the importance of blood, it was actually quite rare for a son to inherit the throne from his father. Horizontal inheritance was much more common, where an established

\footnotetext{
${ }^{46}$ BarbaraYorke, Kings and Kingdoms of Early Anglo-Saxon England (London: Routledge, 1990), 88.

${ }^{47}$ An example of this can be seen in the case of Edmund Ironside (d. 1016). Despite being the son of King Æthelred II, he was never taken very seriously as king, as argued in Ian Howard, Swein Forkbeard's Invasions and the Danish Conquest of England, 991-1017 (Woodbridge: Boydell Press, 2003), 6. One of the principal problems with his bid for kingship was that, despite having royal blood, he had very little military power at his disposal.

${ }^{48}$ William A. Chaney, The Cult of Kingship in Anglo-Saxon England: The Transition from Paganism to Christianity (Berkeley: University of California Press, 1970), 7; Kenneth Sisam, "Anglo-Saxon Royal Genealogies" Proceedings of the British Academy 39 (1954): 326.

${ }^{49}$ Loyn, The Governance of Anglo-Saxon England, 15.
} 
brother or cousin inherited the throne instead. As H.R. Loyn notes, "Records are imperfect but in Wessex after Cenwalh's death in 672 there is no case known of son succeeding father until Ethelwulf succeeded Egbert in 839." ${ }^{50}$ Older family members would have been more established and had more resources at their disposal. As noted above, having military power was an important prerequisite for having a serious claim on the throne.

The other issue with kingship in the Anglo-Saxon period is that there were, during the early periods especially, numerous small rulers who were nevertheless regarded as kings. Some of these rulers were sub-kings who were under the authority of other kings. And then during certain periods there existed a bretwalda, an "overking" whom the other kings acknowledged as somehow superior. The literature of the period uses a multiplicity of titles for these men. Bede alone, in his Historia Ecclesiastica, uses various terms when describing figures, and it is difficult to understand how these titles were distinct. For examples, Bede calls some figures princeps, which he doesn't use as interchangeable with rex, even though some reges can be included in this group. He also uses other titles, such as subregulus, dux, and dux nobilissimus. As Bruce Campbell explains, "It appears that to Bede some potentates were indubitably reges, while others did not unambiguously deserve such a description, but nevertheless had something regal about them.. ${ }^{51}$ Bede also uses various terms for the areas or peoples that these figures ruled over: gens, populus, natio. $^{52}$

${ }^{50}$ Loyn, The Governance of Anglo-Saxon England, 16-17.

${ }^{51}$ James Campbell, "Bede's Reges and Principes.” In Essays in Anglo-Saxon History, 85-98 (London; Ronceverte, WV, U.S.A.: Hambledon Press, 1986), 86.

${ }^{52}$ Campbell, "Bede's Reges and Principes," 86. "Gens is the term Bede uses most commonly, and he uses it indifferently for either a large ethnic group ... or the men of a particular kingdom ... His normal word for what we think of as a kingdom is provincia"; for smaller regions he uses regio. 
Yet behind the endless titles and near-impenetrable hierarchies, there is a certain quality that all Anglo-Saxon kings seem to have shared: they were the leaders of a distinct gentes, or people. As Anderson makes clear, "Usually that gens or populus is associated with a geographic area, but the king's relationship is with those he rules, not the land they chance to inhabit." ${ }^{53}$ This is reflected in the fact that the early kingdoms did not retain any variation of local names but rather were referred to by the tribe that conquered them: Wessex / West Saxons, Essex / East Saxons, East Anglia / Angles, and so on. During the earliest period, some of these gens and associated kingdoms were quite small. For instance, the Isle of Wight, which is only 148 square miles, was at one time considered a distinct kingdom with a distinct people ${ }^{54}$ What constituted a single people changed over time as smaller regions became absorbed into larger ones. However, even conquest did not always guarantee assimilation amongst the Anglo-Saxons. King Æthelwulf of Wessex (d. 858), Alfred the Great's father, had conquered Kent but always maintained it as a separate kingdom, and appointed his son as king over the region. It was not until all of England was overrun by the Scandinavians, and then gradually reconquered by Alfred and his descendants, that the country became united under a single house. Only when faced with the real possibility of subjugation by a foreign foe did the Anglo-Saxons finally recognize themselves as more-or-less a single people. At least until the mid-eleventh century, the king was the man who embodied the tribe, who had the military power to defend his people, and in whose veins ran the blood of Woden. While additional duties and roles would be attached to Anglo-Saxon kings throughout the period, these qualities remained remarkably constant.

\footnotetext{
${ }^{53}$ Anderson, “Ælfric's Kings,” 29.

${ }^{54}$ Campbell, "Bede's Reges and Principes," 92.
} 


\section{Comitatus}

The concept of the comitatus - the loyal band of warriors who accompanied the king - is not generally considered within ecclesiastical contexts. I include an examination of it here to help illustrate the way that kings interacted with followers, and the way Germanic loyalty operated during the early medieval period. The concept of the comitatus later became absorbed into the witan, a circle that ecclesiastics were a key aspect of. In addition, the sense of loyalty inherent in the comitatus and reflected in such works as The Battle of Maldon would be critical concepts for ecclesiastics such as Wulfstan.

Originating in pre-historical tribal structures, the king's comitatus remained a powerful idea throughout the Anglo-Saxon period. The term comitatus refers to a king or lord's group of close followers and has been in use among Anglo-Saxonists since the nineteenth century. ${ }^{55}$ The word was taken from the Germania, a first-century text by the Roman historian Tacitus, who wrote a description of the Germanic peoples then living in Northern Europe. While the term is standard among scholars, it does not actually ever occur in Old English texts. A variety of words and phrases are used instead, such as with Hrothgar's "hælepa gedryht" 56 [band of warriors] or Beowulf, who arrives "mid his hondscole" 57 [with his retinue]. The comitatus is ultimately the tribal idea of a war-band, of the group of warriors who always accompanied the leader. While holding some similarities to the idea of a royal guard, the comitatus generally was portrayed as a more

\footnotetext{
${ }^{55}$ Donald Scragg, "Comitatus.” In The Wiley Blackwell Encyclopedia of Anglo-Saxon England, edited by Michael Lapidge, John Blair, Simon Keynes, and Donald Scragg, 121. Second Edition. Oxford; Malden, Mass.: John Wiley \& Sons, 2014.

${ }^{56}$ Frederick Klaeber, Klaeber's Beowulf and the Fight at Finnsburg. Edited by R. D. Fulk, Robert E. Bjork, and John D. Niles (Toronto; Buffalo: University of Toronto Press, 2008), 1. 662.

${ }^{57}$ Klaeber, Beowulf, 1. 1963.
} 
intimate and emotionally charged relationship. We see something of this emotion in Beowulf when Hrothgar grieves over the death of his man, Æschere, ${ }^{58}$ or in elegies like The Wanderer, where the speaker grieves the loss of his lord. In traditional arrangements, the lord "provided them with food" and the warriors "lived—and slept—in his hall. For exceptional service he gave them rich gifts of rings, weapons, armour and horses, and during times of feasting they vowed absolute loyalty." ${ }^{59}$ At least, this is the idealized relationship we see portrayed in Tacitus and in Anglo-Saxon heroic literature. While Beowulf imagines the comitatus in an early Scandinavian setting, the idea was still important to writers in the late tenth century, as illustrated in works such as The Battle of Maldon.

Written to mark a skirmish between Anglo-Saxon and Viking forces, The Battle of Maldon seeks to celebrate the heroic deeds of those that fought in a battle that otherwise would simply be regarded as a disastrous loss. It immortalizes the earl Byrhtnoth, who died fighting against Viking raiders in 991. Famously, many of his men chose to remain on the battlefield and fight to the death in order to avenge their fallen lord—or at least, this is the version that the poem gives us. ${ }^{60}$ Strategically, the battle was a demoralizing defeat for the English in which they lost one of the nation's most important military

${ }^{58}$ Klaeber, Beowulf, 1. 1306-29.

${ }^{59}$ Scragg, "Comitatus."

${ }^{60}$ While taking revenge for either kin or one's lord was a common aspect of wergild in Anglo-Saxon society, simply seeking death was not. There has been some scholarly debate whether this incident represents a little-known tradition in the ideas of Anglo-Saxon comitatus, a literary invention, or a later development in the obligations of retainers to their lord. See: Dorothy Whitelock, The Beginnings of English Society. 2nd ed. Pelican History of England 2 (Harmondsworth: Penguin, 1986), 29-38; Rosemary Woolf, "The Ideal of Men Dying with Their Lord in the Germania and in The Battle of Maldon" Anglo-Saxon England 5 (1976); Roberta Frank, "The Ideal of Men Dying with Their Lord in The Battle of Maldon: Anachronism or Nouvelle Vague." In People and Places in Northern Europe, 500-1600: Essays in Honour of Peter Hayes Sawyer, edited by I. N. Wood and Niels Lund. (Woodbridge: Boydell Press, 1991); Harris, "Oaths in The Battle of Maldon." 
leaders. ${ }^{61}$ Following the disaster, King Æthelred II paid off the Vikings with 10,000 pounds of silver - the first of many such payments or Danegelds. ${ }^{62}$ But within the context of the poem, the heroic battle to the death seeks to achieve a moral victory within the strategic loss, similar to Greek accounts of Thermopylae.

The overriding theme of Maldon is the importance of loyalty and the bonds of the comitatus; critical to this loyalty was the beot [vow] made by the warrior to his lord. Byrhtnoth expected his men to stand with him loyally during the battle, and we are told that "se eorl nolde yrhðo gepolian" ${ }^{63}$ [the earl would not endure cowardice]. Many of those warriors who stood their ground in The Battle of Maldon recalled their beot in the final moments of struggle. The warrior Eadric, "beot he gelæste / pa he ætforan his frean fehtan sceolde" ${ }^{64}$ [he carried out his vow when he was obligated to fight before his lord]. The word beot indicates a vow made, generally one made from a warrior to a lord, that he will serve in battle for him. Often such vows were made in the meadhall, the place were oaths of fealty are secured and the lord disperses rewards for his loyal followers. To be cut off from this relationship was to destroy the social bonds that held the warrior society together, as can be seen in elegies such as The Wanderer. The beot, then, seems to be the key moment in which a man was bound to a lord, perhaps an early version of later, more formalized, oaths of fealty. That it is repeatedly recalled by those who stand true to Byrhtnoth demonstrates that the idea still carried cultural weight even in the late tenth century. The residual power of this idea was one that penetrated all layers of society,

\footnotetext{
${ }^{61}$ Donald Scragg, "Introduction.” In The Battle of Maldon, 1-56. Old and Middle English Texts. (Manchester: Manchester University Press, 1981), 19.

${ }^{62}$ Geoffrey Hindley, A Brief History of the Anglo-Saxons (New York; [Berkeley, Calif.]: Carroll \& Graf Publishers, 2006), 302.

${ }^{63}$ Donald Scragg, ed, The Battle of Maldon. Old and Middle English Texts. (Manchester: Manchester University Press, 1981), 6.

${ }^{64}$ Scragg, The Battle of Maldon, 15-16.
} 
including ecclesiastics, who also were heirs of this heroic tradition. Their interest in such ideas is made evident in their continual interest in copying and maintaining heroic verse. ${ }^{65}$

Byrhtnoth himself was bound in loyalty to his own lord, King Æthelred II. He declares that he will stand and defend "Fepelredes eard, ealdres mines" ${ }^{\prime 66}$ [Æthelred's country, my leader] Here we can see how the chains of loyalty move up. Just as Byrhtnoth's men stand loyally by him, he stands loyally for his own lord. The themes of loyalty are prominent in the poem, perhaps because loyalty during this time was in short supply. The poem operates to promote loyalty by recalling heroic tradition, and by recalling a contemporary event that echoed that tradition. While there of course is always some disparity between the idealism present in heroic verse and the reality of history, what is important here is that the poet seemed to have thought that recalling that heroic tradition would galvanize those who heard it and inspire similar deeds. The poetry here in many ways echoes the concerns with loyalty by Archbishop Wulfstan, in his Sermo Lupi ad Anglos. As we shall see, Wulfstan and other ecclesiastical writers often thought of their own relationships with secular lords in terms of traditional Anglo-Saxon military constructs, such as the comitatus.

The Maldon poet uses the speeches of the warriors to repeatedly remind the reader repeatedly that vows to a lord should be kept. Elfwine, one of the warriors in the poem, in turn seeks to remind the other warriors of this bond: "Geminap pa mæla pe we

\footnotetext{
${ }^{65}$ Ecclesiastical interest in heroic verse was something that Alcuin famously gave criticism to, although what and who he was actually rebuking is a matter of some debate. See: Donald A. Bullough, "What Has Ingeld to Do with Lindisfarne?" Anglo-Saxon England 22 (1993) for an in-depth overview of the arguments. Bullough also makes a rather compelling claim that the rebuke was not at all levied at a Northumbrian monastic community, but rather to a singular Mercian bishop. ${ }^{66}$ Scragg, The Battle of Maldon, 53.
} 
oft æt meodo spræcon, / ponne we on bence beot ahofon" ${ }^{\text {"67 }}$ [Remember the times that we often spoke at mead, when we raised a vow on the bench]. Ælfwine's words show that the beot was something that needed to be remembered and recalled, and perhaps at times one had to remind others of their obligations as well. The necessity of reminding others indicates that this vow was not entirely internalized. This is especially true for those who fled the battle. Those warriors who declare the duties of the comitatus are like small mouthpieces of the poet, who himself seeks himself to remind the reader of the obligations of loyalty. That these vows were taken in the meadhall, while drinking mead, shows the social rather than legal nature of this bond. In Beowulf we are told how "Ful oft gebeotedon beore druncne / ofer ealowæge oretmecgas / pæt hie in beorsele bidan woldon /Grendles gupe mid gryrum ecga." ${ }^{\prime 68}$ [Full often warriors have boasted, drunk with beer, over the ale-cup, that they would bide in the beer-hall, await Grendel's attack with the terror of swords]. We are never told of any formal rites of the comitatus, only that the warriors pledge to their lord during mead. Perhaps formal rites did exist-if so, it would seem strange that they are not recalled by those warriors thinking of their beot. Perhaps the mead blurred their memories.

The duties and obligations of the comitatus were reciprocal and so differed from other vertical political structures, such as the Roman client system. D.H. Green, in his extended comparison of the Germanic comitatus with Roman patronage, found that the two were fundamentally different:

[The comitatus] is built around the central idea of reciprocity, of mutual

\footnotetext{
${ }^{67}$ Scragg, The Battle of Maldon, 212-13 Here moela is a bit unclear, with some translating it as "words." I follow Scragg here in translating it as "times."

${ }^{68}$ Klaeber, Beowulf, 1. 480-83.
} 
and complementary rights and obligations, especially as exemplified by the idea of loyalty as the essential bond between the individual member of the retinue and his warrior-leader...Here it differs fundamentally from the Roman patronatus, with its unilateral nature and stress on subjection and obedience on the part of the client. This reciprocity of the Germanic relationship means that both parties, the superior and the inferior, share their duties and their privileges, so that, by contrast with the Roman clientela, much greater scope, both legal and moral, is afforded to the subjective element in the follower. ${ }^{69}$

It is important here to acknowledge that Green is basing much of his analysis on the text of the Germania, a text removed several centuries from Anglo-Saxon England. Many scholars would undoubtedly agree with the views of Katherine O'Brien O'Keeffe, who, while acknowledging that "many of the traits which Tacitus describes in his account of the Germanic comitatus are consonant with features of heroic convention found in Old English literature," nevertheless finds the text an "unreliable guide to 'historic' details about either contemporary German barbarians or their post-migration descendants," since Tacitus was a politically biased writer, looking to praise virtues he wanted to promote among Romans. ${ }^{70}$ Yet, this claim cannot be entirely true. As Green points out, Tacitus was

${ }^{69}$ D. H. Green, The Carolingian Lord; Semantic Studies on Four Old High German Words: Balder, Frô, Truhtin, Hêrro (Cambridge: University Press, 1965), 70-74. While I agree with Green on the underlying differences between the Roman client system and the comitatus, he is here somewhat overstating the subjugation of a cliens. As noted in Arnaldo Momigliano, and Tim Cornell. "Cliens." In The Oxford Classical Dictionary, edited by Simon Hornblower, Antony Spawforth, and Esther Eidinow, Fourth edition., 334. (Oxford: Oxford University Press, 2012), 334, there were important elements of reciprocity in the client system. Clients would show support of their patron by greeting him in the morning and accompanying him through the day. In return, the clients received "favours and benefits of various kinds, including daily subsistence in the form of food or money . . and assistance in the courts."

${ }^{70}$ Katherine O'Brien O'Keeffe, "Values and Ethics in Heroic Literature." In The Cambridge Companion to 
somewhat bewildered in trying to comprehend the Germanic comitatus, since "what the Germanic warriors understood by loyalty was something very different from what the Romans understood by fides."71 So, while Tacitus might very well have been biased, it is difficult to imagine him inventing virtues and social hierarchies that confused him, or promoting virtues that were fundamentally alien to traditional Roman systems. While care must be taken when using Tacitus in relation to Old English literature, I nevertheless maintain that it is a useful source to help us think about the nature of Anglo-Saxon royal relationships and power structures.

The concept of the comitatus would continue to influence interactions between the king and his men - including his bishops - until the end of the Anglo-Saxon period. In his analysis of comitatus, Green further considered how such a system would operate at different levels of magnitude:

it is clear that although the idea of loyalty may well prove a sufficiently strong link in the case of the relatively small comitatus, where the relationship was a strongly personal one, it would not prove a firm enough basis in the wider context of the state, where, in addition to the impersonality of the relationship between ruler and subjects (resulting from larger numbers and greater geographical extent), to base political life on the subjective feelings of loyalty in each individual would be to court disaster. What for the state would be chaos was for the comitatus, however, a source of intense moral strength. ${ }^{72}$

Old English Literature, edited by Michael Lapidge and Malcolm Godden, 101-19. (Cambridge; New York: Cambridge University Press, 1991), 107.

${ }^{71}$ Green, The Carolingian Lord, 75.

${ }^{72}$ Green, The Carolingian Lord, 76. 
It is my argument that the kings of Anglo-Saxon England continued, in various ways, to rely on the idea of the comitatus in dealing with bishops and ealdorman. Part of the problems noted above by Green were counterbalanced by the witan, and by the fact that in Anglo-Saxon England the high-ranking nobles and bishops generally accompanied the king as he made his peripatetic rounds in the nation - a situation quite different than continental royal courts. But personal loyalty was a double-edged sword. It was a great strength in the case of Maldon, where Byrhtnoth was loyal to Æthelred. Others, however, lacked this bond. Such was the case with Eadric Streona, ealdorman of Mercia, who was not loyal to Æthelred and sided with Cnut (although he later betrayed Cnut as well, a deed the Danish king repaid by having Eadric killed). ${ }^{73}$ The underlying idea of comitatus helps us to understand why, when Æthelred returned to England to reclaim his throne, he demanded better loyalty, and his subjects demanded that he rule better. ${ }^{74}$ This is the reciprocity of the comitatus in action. As Green notes, these personal relationships as a basis for government could in fact lead to chaos, but he is wrong in thinking it was a completely unworkable system at a state level. It worked, and for the most part very well, for the entirety of the Anglo-Saxon period. ${ }^{75}$ It was also generally the basis for interaction between kings and the bishops, who also were part of the witan and accompanied the king in his peripatetic court. In short, the witan absorbed the more informal comitatus as time went on, and in doing so it absorbed some of its character as well.

\footnotetext{
${ }^{73}$ Hindley, A Brief History of the Anglo-Saxons, 306-9.

${ }^{74}$ Hindley, A Brief History of the Anglo-Saxons, 305.

${ }^{75}$ The nature of this relationship seems to have changed rather dramatically after the Norman invasion in 1066. William the Conqueror was ruthless in his suppression of English magnates and ruled much more absolutely. In some ways, the Norman system of government was closer to the Roman idea of clientela than the Anglo-Saxon comitatus. William did not tolerate dissent and relied upon terror and cultural genocide to subjugate his English subjects. See Hindley, A Brief History of the Anglo-Saxons, 344ff.
} 


\section{The Witan}

The witan was the collective group of great men who advised the king in various matters. The nature, extent, power, and composition of this group have been hotly debated for some time. In the nineteenth century, many Whig historians were eager to see the witan as a proto-parliament, a representative body that would later develop into the parliament of England. Some scholars viewed the meetings of the witan as primitive folkmoots, as large democratic meetings of the people. ${ }^{76}$ The early twentieth century reacted against this view, sometimes seeing the witan as nothing more than personal agents of the king, or even questioning its existence as an institution at all. When Frank Stenton published his Anglo-Saxon England in 1943, he was part of the group of historians eager to move away from teleological interpretations of the witan and those nineteenth-century historians "who read all of English history as a precursor to the modern state." 77 Stenton, in reaction, swung too far in the opposite direction. Instead of simply leaving witan and witenagemot untranslated, he chose to translate them as "King's Council." As Levi Roach rightly notes, "Though this might seem but a minor semantic difference, it reveals a sea change in the way in which assemblies were conceived ... [the witan] had become little more than a royal institution, shorn of representative functions." ${ }^{\text {,7 }}$ As of this writing, Stenton's book continues to be one of the principal historical works used by AngloSaxonists, and the influence of Stenton's semantic choice continues to be felt. It is telling that if one looks up witan in The Wiley Blackwell Encyclopaedia of Anglo-Saxon

\footnotetext{
${ }^{76}$ Loyn, The Governance of Anglo-Saxon England, 101.

${ }^{77}$ Levi Roach, Kingship and Consent in Anglo-Saxon England, 871-978: Assemblies and the State in the Early Middle Ages (Cambridge; New York: Cambridge University Press, 2013), 3.

78 Roach, Kingship and Consent, 3.
} 
England, one is redirected to "King's Council." ${ }^{, 79}$ While those who viewed the witan as a proto-parliament were clearly wrong, the reaction also has tended towards extremes. The trouble is, like many medieval institutions, the powers and nature of the witan were not explicitly codified, but varied, depending upon circumstances and upon the historical period in question.

The power of the witan was probably greatest upon the death of a king, when the witan was charged with giving their consent to the next monarch. This consent was not an election from a list of candidates. As H.R. Loyn notes, this consent "often amounted to no more than formal acquiescence in decisions made elsewhere," yet even still, "those who acquired the throne by conquest or physical strength were most careful to gain the general assent of the witan." ${ }^{\prime 80}$ To some extent, the role of the witan in the succession seemed to have been in making sure the would-be king had the appropriate qualifications. As noted earlier, A king needed to have a certain amount of power and money in order for his reign to be effective, and he also needed to have royal blood.

Beyond the succession, the witan was very involved in the creation of law; this is especially true of the ecclesiastical members; within the day-to-day running of the nation, any act of "more than routine significance" would be carried out with the cooperation of the witan ${ }^{81}$ This element of cooperation and reciprocal duties is key to understanding the way in which early English government functioned, and why it is best understood as an extension of the older comitatus. While nineteenth-century historians saw an overlypowerful democratic witan, and later historians saw mere functionaries of the king, it is

\footnotetext{
${ }^{79}$ Michael Lapidge, John Blair, Simon Keynes, and Donald Scragg, eds. The Wiley Blackwell Encyclopedia of Anglo-Saxon England. Second Edition. (Oxford; Malden, Mass.: John Wiley \& Sons, 2014), 505.

${ }^{80}$ Loyn, The Governance of Anglo-Saxon England, 101.

${ }^{81}$ Loyn, The Governance of Anglo-Saxon England, 101.
} 
best to understand the king and witan as functioning together, sharing both power and responsibility. To be clear, the king was by far the stronger partner in this relationship, and it was only with great difficulty that the witan could oppose a king. Despite this power imbalance, the two seemed to work together with remarkable efficiency. It is important to understand the influence and nature of the witan, because it is in this capacity that the important ecclesiastics of the realm worked with the king, where they were expected to advise him and help him administer the realm.

The process by which bishops became an integral aspect of government was gradual. While Bede advocated for a closer working relationship between bishops and kings, by the end of the ninth century Church councils had been absorbed into the witan and no longer met independently. ${ }^{82}$ There was no longer a clear dividing line between Church business and state business. During the reign of Alfred, the working relationship between the king and the bishops was considerably tightened. Alfred "expected to receive advice from his archbishops and bishops and expected them to be present" in the witan ${ }^{83}$ The king had control over key Church appointments, and "Carolingian theocratic ideals were neatly embodied in much of the institutional life" of Anglo-Saxon kings ${ }^{84}$ The bishops under Alfred served him in ways that clearly echo the older notion of the

${ }^{82}$ Catherine Cubitt, "Councils, Church." In The Wiley Blackwell Encyclopedia of Anglo-Saxon England, edited by Michael Lapidge, John Blair, Simon Keynes, and Donald Scragg, 127-28. Second Edition. Oxford; Malden, Mass.: John Wiley \& Sons, 2014, 128. "After 850, separate meetings for the church cease to be recorded ... From the tenth century, church business appears to have been discussed at meetings of the king and his councilors. This new practice can be seen, for example, in a meeting held at London 941x946, under King Edmund and Archbishop Oda of Canterbury and Wulfstan of York, from which ordinances were issued in the king's name concerning ecclesiastical discipline and spiritual matters for both laity and ecclesiastics. The great council at Winchester attended by bishops, abbots and abbesses, at which the Regularis concordia was imposed upon all English monasteries was convened by King Edgar and held under his authority."

${ }^{83}$ Loyn, The Governance of Anglo-Saxon England, 106.

${ }^{84}$ Loyn, The Governance of Anglo-Saxon England, 106. 
comitatus. Aside from serving by his side in matters of administration, some of his bishops also fought next to him in battle. ${ }^{85}$ During the tenth century, as England was brought under West-Saxon rule, the power of the witan, and therefore of the bishops, increased dramatically. The assemblies of the witan became more regularized and attendance grew as the witan became more involved in various national business. ${ }^{86}$ The Benedictine reform movement, which largely emerged during King Edmund's reign (939946), "ushered in a period of exceptional cooperation between religious and secular domains. Archbishop Oda was the elder statesman of this movement, and he clearly recognized the need for direct mutual aid between ecclesiastics and secular officials under an increasingly powerful king. ${ }^{87}$ In understanding the close working relationship between these churchmen and the state, we need to rethink how we read their writings. The higher-ranking ecclesiastics of this period were not simply priests, but also politicians who sought to influence and affect the direction of government.

One of the principal claims I will be making is that much of the writing that we might consider as religious was at the same time political in nature, and very consciously so. Furthermore, this political motivation was not based on some faint hope of influence, as these men were already intricately enmeshe into the government, at least by the later period. But despite their closeness to the king, they were still subjects, and they had to be careful in the way they used their influence. Advising a powerful king was a tricky matter.

${ }^{85}$ Loyn, The Governance of Anglo-Saxon England, 72.

${ }^{86}$ John Robert Maddicott, The Origins of the English Parliament, 924-1327 (Oxford: Oxford University Press, 2010), 2-3.

${ }^{87}$ Alaric A. Trousdale, "Being Everywhere at Once: Delegation and Royal Authority in Late Anglo-Saxon England." In Kingship, Legislation and Power in Anglo-Saxon England, edited by Gale Owen-Crocker and Brian W Schneider, 276-96. Publications of the Manchester Centre for Anglo-Saxon Studies, 13. (Woodbridge, Suffolk: Boydell Press, 2013), 296. 


\section{Selection of Texts and Overview of Chapters}

In examining ecclesiastical advisors from the Anglo-Saxon period, there were far more options than I could reasonably fit within this work; these options become truly staggering one looks outside of the Anglo-Saxon period. I have decided to focus on Eusebius, Gildas, Bede, Asser, Wulfstan, and to a lesser extent, Sedulius Scottus. There were many other figures that I could have, in theory, examined in this project: Alcuin, who served as advisor to Charlemagne; the many tenth-century figures associated with the Benedictine Reforms, such as Oda, Dunstan, Æthelwold, and Oswald; Ælfric of Eynsham, a contemporary of Wulfstan, whose hagiographical work often encoded political opinions; and other important ecclesiastical theorists, such as Smaragdus, a Benedictine monk in the service of Charlemagne. There are others as well.

My first consideration in selecting texts was to show a development in both the nature of advice literature and theory of kingship throughout the Anglo-Saxon period. It has sometimes been the case that Anglo-Saxon culture and history has been conceived of in monolithic terms. This conception is fed in part by the nature of Anglo-Saxon literature, especially the poetry, which tends to be very conservative in form and content, and thus seemingly exhibits a timelessness throughout the Anglo-Saxon period. Thus, having a broad chronological representation was crucial to the process. I examine Eusebius (260-340) and Gildas (500-570) as precursors and influencers on Anglo-Saxon writing, with the benefit that they also come from different periods and cultures: Eusebius (fourth-century Roman) and Gildas (sixth-century Celtic). These texts help establish that the Anglo-Saxons had precursors and examples of advice literature, and existing conceptions of Christian kingship. Eusebius establishes the idea of a holy Christian ruler 
who establishes the Kingdom of God upon Earth, a concept that would prove important to Anglo-Saxon conceptions of kingship and sanctity. Gildas looks to the Old Testament to find models of kingship, a practice that was ubiquitous among Anglo-Saxon and Carolingian advice literature.

Bede provides us with a window into seventh- and eighth-century kingship and advice, a period during which the Anglo-Saxons were divided into several smaller warring kingdoms. While this "heroic" period in many ways might resemble the world from Beowulf, it was a political situation quite different from the ninth and tenth centuries. I situate Bede's Historia ecclesiastica gentis Anglorum (completed in 731) within the political controversies of the Northumbrian succession crisis, and the political inaction of King Ceolwulf, then king of Northumbria. I analyze Bede's preface to Ceolwulf, and show that he envisioned the king (and potentially other royalty) as his primary audience, and wanted the history to function, among other goals, as an exemplum for good kingship. I then show that through Bede's praise and sanctification of a holy war-king like Oswald (604-642), he was hoping to inspire Ceowulf into a program of aggressive military action.

Asser's 893 biography of Alfred the Great (849-899) allows us to see the changes wrought by the unification under Alfred, and a broader conception of what kingship was thought to entail. Asser looks to Continental models of kingship to promote a conception of king-as-teacher and shepherd of both laity and the Church. While not entirely abandoning the militancy of Bede, Asser draws on Sedulius Scottus' (840-860) concepts of Christian kingship and blends them with elements of hagiography and Carolingian biography to portray Alfred as a holy, suffering figure who would guide society through 
his divinely-given wisdom and war skills. He thus validates a mode of saintly kingship that previously had not been emphasized in Anglo-Saxon England.

Finally, I examine the writings of Wulfstan, Archbishop of York (d. 1023) to highlight the changes manifest just decades before the Norman Invasion. Wulfstan served as advisor to three different kings: Æthelred the Unready, Swein Forkbeard, and Cnut. I focus on two works by Wulfstan: Sermo Lupi ad Anglos and the Institutes of Polity, works which in many ways represent a culmination of Anglo-Saxon advice literature, as he draws on a number of themes that I examine in Eusebius, Gildas, Bede, and Asser. However, Wulfstan abandons the notion of a king ruling over a specific people and instead strongly links the idea of Christian kingship to protection of Christendom itself. In advancing this vision, Wulfstan breaks from older Germanic conceptions of loyalty and looks towards aggressive Christian warfare against unbelievers, a concept that would become fully materialized less than a century later in the First Crusade.

Aside from the chronological and political diversity present in these texts, I also sought to embrace a variety of forms to highlight the various modes in which this type of writing could appear. Eusebius' Tricennial Oration is a panegyric, a work written to give formal and elaborate praise to Constantine. It is, in many places, quite hyperbolic in its laudation, but in doing so reveals Eusebius' highest conceptions of kingship. Gildas' Ruin of Britain is a historical sermon. He relates the downfall of the Britons in sub-Roman Britain, but his focus is on condemning the shortcomings in leadership that led to such a state, and demonstrating the sort of leadership that is needed to reverse the damage. Bede's Historia is an eclectic work draws upon multiple genres. It is a history tracing the development of Christianity in England, but also very much a history of kings. Bede 
applies his judgment to the various kings he presents, often comparing them to Old Testament models. With Asser we have a biography, one which (I will argue) was directed towards the king himself. In many ways it is similar to Eusebius' Tricennial Oration: the figure examined was alive and would have seen the work, and it is overwhelmingly positive to the point of hyperbole. However, where Eusebius' work gives us a static, abstract portrait of Constantine, Asser incorporates a fair amount of material from the Anglo-Saxon Chronciles and stories from the king's youth in order to show the development of Alfred from a boy to a man.

Wulfstan's work in many ways stands apart from those examined in my first three chapters. One technique that unites Eusebius, Gildas, Bede, and Asser is the use of exemplarity to promote conceptions of kingship. Whether through a hyperbolic portrait of the king himself (Eusebius, Asser) or the example of Old Testament figures (Gildas, Bede), there is the use of narrative in order to drive the message. Wulfstan did not prefer to use exempla, history, or metaphors in his writing. His Sermo Lupi is, on the surface, a sermon decrying the immorality he found in his time, and his Institutes of Polity is a document on how to order society. He often wrote in an oral style that would have worked well for public speaking. Yet, despite his seeming bluntness, he can escape censure due to the sheer abstractness of his pronouncements. There is a certain amount of passive-aggressiveness in Wulfstan. While harshly decrying failures in society, he deftly avoids placing the blame directly upon the king, at least within the same document.

The connecting element between these diverse authors and texts is political rhetoric that promoted a vision of kingship. It was a Christian conception of kingship, and one that advanced the goals of the Church. While there is development in this vision 
throughout the time frame I examine, the vision that the writers promote is generally in harmony, rather than conflict. They envisioned a more-or-less similar ideal, but the necessities of the various periods encouraged them to focus on different aspects of this ideal. At the same time, these texts highlight the slow movement of ecclesiastical figures into the business of kings. It is part of the greater scholarly conversation of how native Anglo-Saxon culture absorbed and was transformed by Christian culture, and a growing understanding of how different moments in Anglo-Saxon history gave this process expression through writing. 


\section{CHAPTER 1}

\section{EUSEBIUS AND GILDAS}

While the main focus of this project concerns the writings of Anglo-Saxon ecclesiastics, it will be useful to first consider two of the more important sources for the Anglo-Saxons. When Bede was writing his Historia Ecclesiastica, he was not writing in a vacuum. He drew on a number of traditions, including biblical and historical texts, as models for his content and structure. As I will argue in Chapter 2, Bede was also partially composing his work as a form of advice literature, to influence contemporary ideas about the roles and duties of a king. In this first chapter, I will argue that Eusebius' Tricennial

Oration (c. 336), and Gildas' De excidio et conquestu Britanniae (c. 540) served as early models of advice literature for Anglo-Saxon writers, while also creating the theoretical foundation for Christian kingship. ${ }^{1}$ This foundation blends two important strains of Christian thought: from Eusebius comes a Christian Platonism that locates the king within the divine and ecclesiastical hierarchy, while Gildas promotes a tradition of ecclesiastical criticism rooted in Old Testament kings and prophets.

\footnotetext{
${ }^{1}$ There is no complete list for what works Bede had in his library. We do know that he had access to Gildas and Eusebius' Ecclesiastical History, although he would have read Eusebius in Rufinus' Latin translation. See: M.L.W. Laistner, "The Library of the Venerable Bede." In Bede: His Life, Times, and Writings: Essays in Commemoration of the Twelfth Centenary of His Death, edited by A. Hamilton Thompson, 237-66. (New York: Russell \& Russell, 1966); John Marsden, Northanhymbre Saga: The History of the Anglo-Saxon Kings of Northumbria (London: Kyle Cathie, 1992), 9; Alan Thacker, "Bede and History." In The Cambridge Companion to Bede, edited by Scott DeGregorio, 170-89. Cambridge Companions to Literature. (Cambridge; New York: Cambridge University Press, 2010), 172; Helmut Gneuss and Michael Lapidge. Anglo-Saxon Manuscripts: A Bibliographical Handlist of Manuscripts and Manuscript Fragments Written or Owned in England up to 1100. Toronto AngloSaxon Series 15. (Toronto: University of Toronto Press, 2014); Michael Lapidge, The Anglo-Saxon Library (Oxford; New York: Oxford University Press, 2006).
} 


\section{The Eusebian Vision}

By modern definitions, Eusebius' writings can be divided into two groups:

political and theological. These distinctions, however, are anachronistic and would have likely baffled Eusebius himself, as the majority of his works concern both the physical and spiritual aspects of humanity. A fourth-century bishop and prolific writer, Eusebius of Caesarea (c.260-c.339) is probably best remembered as the author of the Ecclesiastical History, a universal history of the Church leading up to his own time. His two works on Constantine (Tricennial Oration and Vita Constantini) are "the most important contemporary" works for Constantine I, the first Christian emperor of the Roman Empire. $^{2}$ In modern times his reputation has suffered, often because of his enthusiastic support for Constantine. In 1853 Jacob Burckhardt described Eusebius as "the most objectionable of all eulogists" and the "first thoroughly dishonest historian of antiquity.", Later scholars have sought to redeem Eusebius by distancing him from Constantine; in Devin Singh's estimation, this distancing manuver stems from a modern "unease with the relation between religion and politics." "4 But as Francis Oakley has argued:

At the heart of primitive and archaic 'politics,' then, lay one form or another of the cosmic 'religion'-so much so, indeed, that for the greater

\footnotetext{
${ }^{2}$ Howatson and Chilvers, "Eusebius." M.C. Howatson and Ian Chilvers, eds., "Eusebius." In The Concise Oxford Companion to Classical Literature. (Oxford University Press, 2011), www.oxfordreference.com

3 Jacob Burckhardt, The Age of Constantine the Great. Translated by Moses Hadas. (New York: Pantheon, 1949), 260, 283.

${ }^{4}$ Devin Singh, "Eusebius as Political Theologian: The Legend Continues." Harvard Theological Review 108, no. 1 (January 2015): 129. Singh lists the following works as examples of this modernising attempt: Timothy D. Barnes, Constantine and Eusebius (Cambridge: Harvard University Press, 1981); Michael J. Hollerich, "Religion and Politics in the Writings of Eusebius: Reassessing the First 'Court Theologian," 'Church History 59 (1990): 309-25; idem, Eusebius of Caesarea's Commentary on Isaiah (Oxford: Clarendon, 1999); Aaron P. Johnson, Ethnicity and Argument in Eusebius' Praeparatio Evangelica (Oxford: Oxford University Press, 2006).
} 
part of human history it is an egregious anachronism even to make use of those words, the very definitions of which presuppose our modern Western distinction between the religious and the political and evoke misleading intimations of the modern church-state dialectic. ${ }^{5}$

Attempts to separate the political and religious in late classical and early medieval writing distorts the worldview from which these texts were written. It is my position that ecclesiastic writers like Eusebius saw no conflict or separation between religious and political life. In fact, his entire theory of kingship absolutely depends on these two not being separate. For Eusebius, as well as for Anglo-Saxon ecclesiastic writers, what moderns would call "politics" was merely a small part of "religion," because religion, far from being a privately held belief, was the framework in which the cosmos was understood. A political arrangement could only make sense as part of God's creation and a divine providential plan.

While Eusebius was not the first religious figure to offer commentary about a ruler (especially if we include Old Testament prophets), he was the first Christian ecclesiastic to create a theological underpinning for Christian rulership; before Constantine, there was no need to do so. ${ }^{6}$ This is critical, as Eusebius then becomes the baseline position from which we can consider later writers, both in terms of kingship theory and in terms of ecclesiastical advice itself. A common trope in advice literature is to use exempla, stories of figures considered to be models of good kingship, as a way of criticizing or encouraging a ruler. Strangely enough, the exemplum could at times be the

\footnotetext{
5 Oakley, Kingship, 17.

${ }^{6}$ Norman Baynes, "Eusebius and the Christian Empire." In Byzantine Studies and Other Essays, edited by Norman Baynes, 168-72. (London: Althone Press, U of London, 1955), 168; F. Edward Cranz, "Kingdom and Polity in Eusebius of Caesarea." The Harvard Theological Review 45, no. 1 (1952): 47.
} 
ruler himself. In effect, writers sometimes created idealized versions of a ruler in order to show them a mirror for what they could aspire to, thus mirror-for-princes. In the case of Eusebius, he did precisely this, because he had no prior exempla of Christian kings to draw on.

Eusebius describes Constantine's government as a reflection of God's heavenly kingdom. A description of Constantine shows him as "he directs his gaze above, and frames his earthly government according to the pattern of that Divine original, feeling strength in its conformity to the monarchy of God." ${ }^{.7}$ This concept is in many ways strikingly new, at least from within a Christian framework. Rather than living in expectation for the kingdom of God in the afterlife, Eusebius claims that, to some extent, a Christian ruler could bring heaven down to earth by modeling himself after God. Constantine's empire "is a replica of the kingdom of heaven, the manifestation on earth of that ideal monarchy which exists in the celestial realm." ${ }^{8}$ It is Constantine's earthly duty to prepare people for heaven, therefore becoming an important part of the salvation process. ${ }^{9}$ For Eusebius then, the emperor was not merely a layman who should protect the Church and oversee secular affairs. Rather, Constantine was a part of the Church in some way and held a sacred office; he was set apart from laymen in both privilege and duty. The exact nature of this office is left somewhat vague, however, and theories about the role of kings would continue to develop and be in dispute throughout the Middle Ages and Early Modern period.

\footnotetext{
${ }^{7}$ Eusebius, "Oration in Praise of Constantine." In Nicene and Post-Nicene Fathers, edited by Philip Schaff and Henry Wace, translated by Ernest Cushing Richardson, Vol. 1. Second Series. (Buffalo, NY: Christian Literature Publishing Co., 1890), 3.5, http://www.newadvent.org/fathers/2504.htm.

${ }^{8}$ Barnes, Constantine and Eusebius, 254.

${ }^{9}$ Barnes, Constantine and Eusebius, 254.
} 
Despite laying the groundwork for Christian kingship, Eusebius drew his ideas from decidedly non-Christian sources. Baynes has argued that Eusebius' ideas of kingship are "the point of confluence of all Oriental, Hellenistic, and Ante-Nicene Christian conceptions. ${ }^{.10}$ While there isn't room here to properly address the ways Eusebius was drawing on Oriental models, suffice to say that the concept of a God-Emperor was common enough in the ancient world. ${ }^{11}$ Obviously Eusebius cannot claim divinity for Constantine, but he comes quite close at times. In envisioning a Christian monarchy, the New Testament did not provide Eusebius much guidance. As Oakley notes, "the range of political ideas to be found in the New Testament did not equip Christians in the early fourth century very well when they had to find a way to come to terms with contemporary theories of imperial rulership and their characteristic stress on the exalted and sacred nature of the emperor."12

The New Testament presents Christ and his Disciples as devoted to a spiritual kingdom, rather than a physical one. Rome is depicted as an antagonistic force, and Christ's most political moment was perhaps when he was asked whether it was lawful to pay taxes, a question he strongly resists: "Why do you tempt me, ye hypocrites? Shew me the coin of the tribute. And they offered him a penny. And Jesus saith to them: Whose image and inscription is this? They say to him: Caesar's. Then he saith to them: Render therefore to Caesar the things that are Caesar's; and to God, the things that are God's." ${ }^{13}$ During the time of Christ, there was no overlap between the realm of God and the realm of Caesar-at least not for Christians. For pagans this conflict had not existed. Long

\footnotetext{
${ }^{10}$ Baynes, "Eusebius and the Christian Empire," 172.

${ }^{11}$ For a broad discussion of kingship in the ancient world, see Oakley, Kingship, 1-68.

${ }^{12}$ Oakley, Kingship, 69-70.

${ }^{13}$ Matthew 22:18-21. Douay-Rheims translation.
} 
before Constantine embraced Christianity, the emperor had held a religious office as part of his duties. The emperor was Pontifex Maximus, the head of the College of Pontiffs (literally "the greatest bridge-builder"), a title that would later be adopted by the Pope. ${ }^{14}$ The Romans did not see a conflict between religious and political life, and thus there was a great amount of intermingling between political and religious offices. It was the antagonism of Rome towards Christianity that kept Christian religion out of the Roman government hierarchy, not a concept of separation. For early Christian thinkers, the Roman Empire was "one of the powers ordained by God," but it was a pagan institution, and so "the question of human government" was "only peripheral to their thought." 15 With Constantine, Eusebius could envision a Christian empire ruled by a Christian emperor. Because the New Testament was lacking in theories of kingship, Eusebius had to look elsewhere. For the most part, Eusebius, like many early Church Fathers, drew on Platonic ideas to provide the framework for his theology. ${ }^{16}$

Eusebius' theology of kingship is quite complex, and there are a number of scholarly debates concerning the exact nature of his hierarchy and Constantine's relationship to God. I will trace here just the briefest of outlines. Eusebius' ideas rest on the assumption that any earthly power ultimately must "derive its meaning from God," and that "The divine kingdom is in some way the original, the archetype, the reality," therefore "all other kings must be related to it as image or symbol or shadow. Any human kingdom is therefore in some sense the reflection of a divine original. ${ }^{17}$ Eusebius also

\footnotetext{
${ }^{14}$ John North, "Pontifex / Pontifices." In The Oxford Classical Dictionary, edited by Simon Hornblower, Antony Spawforth, and Esther Eidinow, Fourth edition, 1183. (Oxford: Oxford University Press, 2012), 1183; Gary Forsythe, A Critical History of Early Rome: From Prehistory to the First Punic War (Berkeley: University of California Press, 2005), 136.

${ }^{15}$ Cranz, "Kingdom and Polity in Eusebius of Caesarea," 47.

${ }^{16}$ Singh, "Eusebius as Political Theologian," 136.

${ }^{17}$ Cranz, "Kingdom and Polity in Eusebius of Caesarea," 52.
} 
connects the concept of monarchy with monotheism, arguing that the Jews abandoned the many gods for one God just as they abandoned tribal life for monarchy. ${ }^{18}$ This human development was made complete through two events: the Incarnation of Christ and the rise of the Christian empire. ${ }^{19}$ Here and elsewhere, the role of the emperor is closely linked to that of Christ, but Eusebius' theology on this relationship is not entirely clear, and scholars have differing opinions about how Eusebius envisioned the arrangement of the spiritual hierarchy.

Eusebius depicts Constantine as being beyond the desires and concerns of mortal men, of existing in an exalted, saintly position. Indeed, in the East at least, Constantine would be regarded as a saint after his death. Just as many hagiographies demonstrate a saint's holiness, so Eusebius shows Constantine's worthiness of being the first Christian emperor by his purity, since he is "above the thirst of wealth, superior to sexual desire; victorious even over natural pleasures; controlling, not controlled by, anger and passion." ${ }^{20}$ For Eusebius, Constantine could claim lordship over other Christians because he had "gained the victory over those passions which overmaster the rest of men." 21 And yet Eusebius goes even further, elevating Constantine beyond the mere human.

\section{Constantine's}

character is formed after the Divine original of the Supreme Sovereign ... [his] mind reflects, as in a mirror, the radiance of his virtues. Hence is our emperor perfect in discretion, in goodness, in justice, in courage, in piety, in devotion to God: he truly and only is a philosopher, since he knows

\footnotetext{
${ }^{18}$ Cranz, "Kingdom and Polity in Eusebius of Caesarea," 52.

${ }^{19}$ Cranz, "Kingdom and Polity in Eusebius of Caesarea," 52.

${ }^{20}$ Eusebius, "Oration in Praise of Constantine," 5.4.

${ }^{21}$ Eusebius, "Oration in Praise of Constantine," 5.4.
} 
himself, and is fully aware that supplies of every blessing are showered on him from a source quite external to himself, even from heaven itself. Declaring the august title of supreme authority by the splendor of his vesture, he alone worthily wears that imperial purple which so well becomes him. ${ }^{22}$

As the last line indicates, Eusebius sets the standard impossibly high so that there can be no question of usurpers or competing claimants (a situation all too common during the late empire), as Constantine was both formed and selected by God to be the earthly ruler over all Christians. It set an impossibly high model of rulership, however, as any ruler after Constantine would fail miserably to live up to the image. But much as the life of a saint was meant to provide an exemplum of extreme holiness for a Christian to aspire to, so Eusebius' portrait provides an exemplum for a Christian ruler. And just as none could hope to match the holiness presented by Christ, so few rulers could hope to actually live up to the portrait Eusebius presents. But the idea inherent in such perfect models is that one strives as best as one is able to live up to the standard. And thus Constantine would remain, throughout the Middle Ages, the paragon of Christian rulership to which all kings should aspire. ${ }^{23}$ By connection, Eusebius himself would become the model of the ecclesiastical advisor. Nevertheless, the height to which Eusebius raises Constantine creates some theological issues.

Constantine's likeness to Christ makes him a partner with Christ on a level far above any priest or bishop. Daniel Stringer outlines the hierarchy thus: "Constantine is the third in a progression of royal figures, the first being God the Father and the second

${ }^{22}$ Eusebius, "Oration in Praise of Constantine," 5.4.

${ }^{23}$ Barnes, Constantine and Eusebius, 273. 
being the Logos-Christ. This Logos-Christ himself is the archetypal image of the Father while the emperor in the third position is the image of the Logos-Christ"24 This neat hierarchy would clearly place Constantine above any other human on earth, including those in the priesthood. But in a different place within the same article, Stringer shows that "Constantine was for Eusebius a kind of second savior." 25 This theological arrangement where Constantine works alongside Christ rather than under him is clarified in Harold Drake's analysis: "Constantine is conceded a special relationship to the supreme God ... [God] rules the world through His Logos, but uses no intermediary when dealing with Constantine." Eusebius' hierarchy "is not so much God-LogosEmperor as God working through two coordinate powers in Heaven and on earth, each identified by the title of his 'Prefect."' 26 As Singh correctly points out, "Such parallelism and coordinate complementarity present difficulties for a single chain of authority and representation." ${ }^{27}$ The exact relationship between a Christian king and either God or Church would remain vague through much of the Middle Ages, and different ecclesiastical figures would formulate these relationships differently. Still, by the time we get to King Alfred's reign, the Church seems to have accepted a viewpoint that was fairly close to Eusebius' position.

As I shall argue throughout this project, it is important to remember that the ecclesiastical vision of kingship was not necessarily the vision the king himself had.

\footnotetext{
${ }^{24}$ Daniel Stringer, "The Political Theology of Eusebius Pamphili, Bishop of Caesarea." Patristic and Byzantine Review 1 (1982): 141.

${ }^{25}$ Stringer, "The Political Theology of Eusebius Pamphili, Bishop of Caesarea," 138.

${ }^{26}$ Harold Drake, In Praise of Constantine: A Historical Study and New Translation of Eusebius' Tricennial Orations. University of California Publications: Classical Studies 15. (Berkeley: University of California Press, 1976), 57.

${ }^{27}$ Singh, "Eusebius as Political Theologian," 139. Singh's article tries to find a compromise between the two conflicting positions, and his work is a good starting point for those interested in exploring the intricacies of Eusebius' political theology.
} 
Ecclesiastics consistently understood kingship as first and foremost a spiritual office and saw the king as a reflection of God on earth. It is perhaps surprising to note that it was not the kings, but rather the ecclesiastics themselves who continually elevated the kings to such an exalted position. But since the ecclesiastic viewpoint was the only one recorded, we do not usually get to see the direct thoughts of the king (Alfred being a remarkable exception). ${ }^{28}$ Many medieval kings seem to have taken their sacral function quite seriously, but, as I argue, if every medieval king fit the ecclesiastical vision of kingship, then there would be no need for the existence of advice literature. The fact that ecclesiastics were writing about what a king should be indicates that the men who sat on the throne did not always (ever?) live up to the standards of the priests. Thus, it must be remembered that advice literature is by its very nature always persuasive writing. So, in the case of the Tricennial Oration, Eusebius very much wants to convince his audience, including Constantine himself, of what a Christian monarch should be. Those who consider Eusebius to be a bad historian or theologian simply misunderstand his purpose and anachronistically attempt to judge him by standards that he was not working in. By understanding Eusebius as advice literature, as the beginnings of a larger tradition, his purpose of establishing Christian kingship becomes more sensible. However, Eusebius' embrace of Christian empire was not without its detractors.

Writing almost a century later in De civitate Dei (c. 426), Augustine dismisses the importance of earthly institutions and instead advocates identifying with the spiritual kingdom of God. In contrast to Eusebius, Augustine sees no hope in a Christian society,

\footnotetext{
${ }^{28}$ Medieval kings were not generally writers. King Alfred was the first English king to author a work, in the late ninth century. And then it would be over seven-hundred years before the next instance, when James I wrote his treatise on the divine right of kings, the Basilikon Doron, in 1598.
} 
and certainly does not see the emperor as part of God's plan of salvation. "To Augustine, the structure of the Christian Roman Empire is still that of Babylon, and human society is still a mixture of two opposed cities, the earthly city and the city of God."29 The only use Augustine saw for government (either Christian or pagan) was as a "'punishment and remedy' for our sinful condition."30 He declared that no peace could be found in the earthly city, only in the heavenly city.31 In light of his reading of Augustine's City of God, Cranz has declared that "Eusebius has no successor as a 'political theologian"' in the West, apparently seeing Eusebius' framework as an isolated aberration within an otherwise Augustinian vision of society in the West. ${ }^{32}$ This view is somewhat understandable in light of the influence Augustine was to have on Western theology, but ultimately it misunderstands how Augustine was received during the Middle Ages. As Oakley points out, Augustine was repackaged and "simplified" through the writings of Gregory the Great, and "the Augustine whom one encounters in the political thinking of the western (or Latin) Middle Ages is not the Augustine whom one encounters in the pages of the City of God."33 This work was reinterpreted by medieval writers through the tracts that Augustine wrote against the Donatist heretics, where he claims, in contrast to the City of God, "that Christian rulers were bound to use their power to punish and coerce those whom the ecclesiastical authorities condemned as heterodox."34 Later writers would selectively quote from Augustine and soften his stance until, eventually, Augustine himself was being used to defend the notion of Christian kingship:

\footnotetext{
${ }^{29}$ Cranz, "Kingdom and Polity in Eusebius of Caesarea," 47.

${ }^{30}$ Oakley, Kingship, 90.

${ }^{31}$ Augustine [of Hippo]. The City of God against the Pagans. Edited by R. W. Dyson. (Cambridge: Cambridge University Press, 1998), 19.27.

${ }^{32}$ Cranz, "Kingdom and Polity in Eusebius of Caesarea," 47.

${ }^{33}$ Oakley, Kingship, 89.

${ }^{34}$ Oakley, Kingship, 90.
} 
In effect, and by one of those superb ironies in which the history of ideas abounds, the name and prestige of Augustine became one of the instrumentalities whereby archaic notions of sacral kingship, to all intents and purposes excluded by the New Testament vision of politics, were nevertheless able to survive in Latin Christendom ... Charlemagne himself, certainly—and Einhard, his biographer, tells us that he was especially fond of Augustine's City of God - felt, like Constantine before him, that he had a particular responsibility for the welfare even of those Christians who lived beyond the confines of Christendom. ${ }^{35}$

So ultimately, whether he is given credit for it or not, the Eusebian vision of kingship was to win out over the Augustinian denial. The conception that a king was ordained by God and that his rule should reflect God's heavenly kingdom was fundamental to many later monarchies and the establishment of Christendom. ${ }^{36}$ It is a political vision that is derived more from pagan ideas of sacral kingship and platonic philosophy than the New Testament. Ultimately, there was a tension between the exaltation of an earthly ruler, and the humble asceticism of Christ. However, as will be seen, ecclesiastical writers would resolve this by drawing on Old Testament models of kingship and by identifying with Old

\footnotetext{
${ }^{35}$ Oakley, Kingship, 91.

${ }^{36}$ I realize that I am making a large jump between Eusebius and the middle ages. The transmission of what I am calling the Eusebian Vision to medieval eccesiastics was not direct, but rather passed through numerous figures. While it may not be possible to trace a direct transmission path, it is clear from documentary evidence that from the Late Classical Period up through the middle ages eccesiastics embraced the idea of sacral kingship and something close to the Eusebiuan Vision. This evidence is traced in some detail by Oakley, Kingship, 76-79: Pope Leo I (440-61) acknowledged the "sacerdotal power" of the emperor, but this was resisted by Pope Gelasius I (492-6), who declared that no man could hold both royal and sacral authority. However, those popes who followed Gelasius rejected this position and "reverted instead to fully traditional attitudes." In the East, Byzantine Emperors also asserted their sacral character, such as when the eighth-century emperor Leo III reminding the pope "that he himself though emperor, was also a priest."
} 
Testament prophets. This was certainly the case with Gildas, to whom we now turn.

\section{Gildas and the Old Testament}

Gildas wrote in an environment dramatically different from that in which Eusebius was writing. Gildas, a British monk, wrote his De excidio et conquestu Britanniae (Ruin of Britain) in the turbulent sixth century, as lingering Christian and Roman institutions were falling apart and the British were being dominated by the alien and pagan Anglo-Saxons. It was a situation somewhat similar to that of Augustine, who wrote his City of God in response to the invasions of Rome by barbarians. But, as I will argue, Gildas looks to a Eusebian vision of kingship rather than an Augustinian preference for a spiritual kingdom. However, Gildas supplements Eusebius' exaltation of kingship by using Old Testament models for both kings and advisors, and an understanding of the British people as a latter-day Israel. This use of the Old Testament for models of kingship and advice would become an essential component for many Anglo-Saxon ecclesiastical writers, as it allowed them to have a kingship model that was grounded in Scripture. Bede especially, who used Gildas extensively, drew upon this model of Old Testament exempla. ${ }^{37}$

Gildas interpreted the history of the Britons in a providential sense that he took from the Old Testament. He understood the overthrow of the British Christians as a punishment from God for their sins: "God, meanwhile, wished to purge his family, and to cleanse it from such an infection of evil" through the ravages of "the old enemy," the Saxons. ${ }^{38}$ The Saxons would serve as an external threat against sinfulness, just as the

\footnotetext{
${ }^{37}$ M. Miller, “Bede's Use of Gildas.” The English Historical Review 90, no. 355 (1975): 242.

${ }^{38}$ Gildas, The Ruin of Britain, and Other Works. Edited and translated by Michael Winterbottom. History
} 
Vikings would in a later period. Indeed, Bede would later agree with Gildas's analysis and take it one step further. According to Bede, God's judgment against the British was final. Not only would the Anglo-Saxons make war against the British, but completely supplant them as God's newly chosen people for the island. ${ }^{39}$

The idea of being a chosen people, shared by Bede and many Anglo-Saxon writers, was also an idea that Gildas held for his own British people. In many places he likens events in Britain to those told of Old Testament Israelites:

In just punishment for the crimes that had gone before, a fire heaped up and nurtured by the hand of the impious easterners spread from sea to sea. It devastated town and country round about, and, once it was alight, it did not die down until it had burned almost the whole surface of the island and was licking the western ocean with its fierce red tongue. So it was that in this assault, comparable with that of the Assyrians of old on Judaea, there was fulfilled according to history for us also what the prophet said in his lament: 'They have burned with fire your sanctuary on the ground, they have polluted the dwelling-place of your name. ${ }^{40}$

from the Sources 7. (London: Rowman and Littlefield, 1978), 22.1. Gildas. Gildae de Excidio Britanniae, Fragmenta, Liber de Paenitentia, Accedit et Lorica Gildae: The Ruin of Britain, Fragments from Lost Letters, The Penitential, Together with The Lorica of Gildas. Edited by Hugh Williams. (London: Published for the Honourable Society of Cymmrodorion by D. Nutt, 1899), 22, p. 50: "volente Deo purgare familiam suam et tanta malorum labe infectam."

${ }^{39}$ Malcolm Godden, "Biblical Literature: The Old Testament." In The Cambridge Companion to Old English Literature, edited by Malcolm Godden and Michael Lapidge, 214-33. (Cambridge: Cambridge UP, 2013), 214-16.

${ }^{40}$ Gildas, The Ruin of Britain, 24.1. Gildas. Gildae de Excidio Britanniae, 24, p. 56: "Confovebatur namque ultionis iustac praecedentium scelerum cause de mari usque ad mare ignis orientali sacrilegorum manu exaggeratus, et finitimas quasque civitates agrosque populans non quievit accensus, donec cunctam paene exurens insulae superficiem rubra occidentalem trucique oceanum lingua delamberet. In hoc ergo impetu, Aassyrio olim in Iudaeam comparando, completur quoque in nobis secundum historiam, quod propheta deplorans ait: Incenderunt igni sanctuarium tuum; in terra polluerunt tabernaculum nominis tui." Gildas is quoting here from Psalm 74.7. 
Not only does Gildas describe Britain as a new Israel, but he also in many places sees Old Testament prophecy as applying to both Israel and Britain. This is an important part of his text, as he quotes extensively from prophets as a way of critiquing contemporary rulers, and these prophets are a major source of inspiration for him. Again, later writers such as Bede would also, at times, see themselves as latter-day prophets who warn secular figures of the will of God.

One important Old Testament figure for Gildas (and later, Bede) was Samuel. ${ }^{41}$ Gildas describes him thus:

We are met first by Samuel, who, at the orders of God, established a lawful kingship, and was dedicated to God before his birth; from Dan to Beersheba he was a truthful prophet to all the people of Israel, and one known by tokens that were truly wonderful. From his mouth the holy spirit spoke in thunder to all the powers of the world, denouncing Saul, first king of the Hebrews, for infringements in obeying the orders of the Lord. ${ }^{42}$

Samuel can be seen here as a prototype for the would-be ecclesiastical advisor. It is Samuel who "established a lawful kingship." This takes the authority of kingmaking and places it firmly into the hands of religious officials. Without the sanction of the Church, and therefore of God, a king cannot be lawful. Historically, of course, there were kings

${ }^{41}$ Michelle P. Brown, "Bede's Life in Context." In The Cambridge Companion to Bede, edited by Scott DeGregorio, 3-24. Cambridge Companions to Literature. (Cambridge; New York: Cambridge University Press, 2010), 9. Brown points out that Bede wrote a "highly personal preface within it," thus showing that he "harboured a telling personal affinity with Samuel, the prophet-priest, who anointed Saul and David and established the sacral role of kingship mediated through, and regulated by, the priesthood."

${ }^{42}$ Gildas, The Ruin of Britain, 38.1-2. Gildas. Gildae de Excidio Britanniae, 38, p. 98: "En primus occurrit nobis Samuel iussu Dei legitimi regni stabilitor, Deo antequam nasceretur dedicatus, a Dan usque Bersabee omni populo Israhel veridicus propheta, signis indubitanter admirandis notus, ex cuius ore Spiritus Sanctus cunctis mundi potestatibus intonuit, denuntiando primo regi apud Hebracos dumtaxat Sauli pro eo, quod quaedam de mandatis." 
who did not meet the approval of the religious elite. But from a very early period one can observe the concept of religious sanction giving authority to a king. ${ }^{43}$ The second task Samuel takes on is in denouncing a king who is not "obeying the order of the Lord." This, at its root, is the very basis of ecclesiastical advice literature, as I define it, and Gildas (among others) found his inspiration for such activity in Old Testament figures like Samuel.

Gildas saw kingship as essentially connected to the Church, and so it was the role of ecclesiastics to advise and guide kings, just as Samuel is seen to do in the Old Testament. Whereas Eusebius in many ways approaches kingship as a Christian Platonist, Gildas sees himself very much in the role of prophet. It is my contention that these two approaches together form the basis for early medieval advice literature. Where Eusebius parses abstract theological concepts, Gildas (like an Old Testament prophet) is much more concerned with criticizing behavior and responsibilities, and criticizing those who do not live up to the high role of king. ${ }^{44}$ Just as Samuel was often quite antagonistic to Saul, an ecclesiastic advisor could be quite antagonistic to the king (as Gildas here is). However, this could also put the advisor in a precarious position and there were limits to the amount of correction a king would take. ${ }^{45}$ Because kings could be dangerous to critics, it was best to distance oneself from the criticism. Anglo-Saxon writers such as

\footnotetext{
${ }^{43}$ Salvatore Paterno, The Liturgical Context of Early European Drama (Potomac: Scripta Humanistica, 1989), 102-08. Paterno notes the early religious rite of Germanic tribes of raising a ruler upon a shield, a sacral practice still found in the coronation of Byzantine emperors as late as the thirteenth century (see Oakley, Kingship, 14). The Old Testament also supports the anointing of kings by religious figures: I Kings 1:32-48, II Kings 11:12-20. According to Paterno, the earliest reference to a Christian anointing of a king by a priest is c.590, where Pope Gregory wrote, "the king's head is anointed because his whole being is overflowing with the Divine Physician's spiritual favors and grace."

${ }^{44}$ It should be noted, however, that both men provided a positive exemplars from which other kings could model themselves: Constantine (Eusebius), Ambrosius and David (Gildas).

${ }^{45}$ As illustrated in the case of Eadwig and Dunstan in the introduction.
} 
Bede would continue the mode of advice literature exhibited by Gildas, using the kingships of David and Saul, and other Old Testament figures as exempla in order to create deniability.

Gildas contrasts the bad kingship of Saul with the good kingship of David to show that the piety of a king affects the well-being of the entire nation. It was because of Saul's sinfulness that the Hebrews were given over to the ravages of the Philistines, again, just as Gildas saw his own Britain handed over to the invading Saxons. What is notable is that the actions of a king, in this case Saul, can affect an entire people. In contrast, Gildas tells us, when David sinned, God sent a plague against Israel, and David "prayed to die for his countrymen, so that the plague should not touch them, saying: 'It is I who sinned, I was the shepherd and I did wrong." ${ }^{46}$ In this way David accepts the responsibility for his sins and seeks to direct the punishment of God away from the people and direct it towards himself as a person. This incident sets up the tension between the king as a man and king as one who embodies the entire nation. To what extent a king had a private spirituality, as opposed to the public spirituality of office, was a matter of debate that would continue throughout the Anglo-Saxon period and beyond ${ }^{47}$ For this reason, David would remain an important figure for kings like Alfred, who were concerned about how their personal piety affected the health and wellbeing of the nation.

Gildas, through his quotations of Ezekiel, shows that between the people and the king, the greatest onus for piety is placed upon the king:

\footnotetext{
${ }^{46}$ Gildas, The Ruin of Britain, 39.3. Gildas. Gildae de Excidio Britanniae, 39, p. 102: "illos plaga non tangeret mori optasset dicendo: Ego sum qui peccavi, ego pastor inique egi."

${ }^{47}$ Ernst Hartwig Kantorowicz, The King's Two Bodies; a Study in Mediaeval Political Theology (Princeton: Princeton University Press, 1957). Kantorowicz outlines the political-theological conept of a king's two bodies in the Middle Ages, that a king had a natural body like other men, but that he also had a spiritual body that served as a symbol of the kingdom and granted him the divine right to rule.
} 
Hear, all you kings, and understand, learn, you judges of the ends of the earth: give ear, you who control multitudes, and have your way among the thronging nations. God gave you your power; your virtue is from the most high. He will inquire into what you do, and scrutinize your thoughts. You were servants of his kingdom, yet you did not judge aright, or keep the law of justice, or walk according to his will; swiftly and dreadfully shall he come upon you, for those who rule will receive the harshest judgment.

Pity is granted to the small; but the powerful shall suffer powerful torments. The ruler of all will have no respect of persons, nor will he stand in awe of anyone's greatness; it was he who made great and small, and his care goes out equally to all. But the stronger will receive stronger torture. ${ }^{48}$ While the people may suffer for the sins of an evil king, the king himself will suffer more. As ruler and judge, he is held to a different standard than the average Christian, and has an elevated role within providential history. While Eusebius elevated kingship, emphasizing the privileges of one who participates in the salvation of his people, Gildas emphasizes the duties and responsibilities that come with that elevation. It is a case of theory vs. praxis, in that Gildas in many ways is sorting out the ramifications of an elevated sacral kingship, while also reminding kings that they still must answer to God.

\footnotetext{
${ }^{48}$ Gildas, The Ruin of Britain, 63. Gildas. Gildae de Excidio Britanniae, 63, p. 146-48: "Audite, inquit, omnes reges et intellegite, discite, indices finium terrae: praebete aures vos, qui continetis multitudines et placetis vobis in turbis nationum. Quoniam data est a Deo potestas vobis et virtus ab altissimo, qui interrogabit opera vestra et cogitationes scrutabitur: quoniam cum essetis ministri regni illius, non recte iudicastis neque custodistis legem iustitiae neque secundum voluntatem eius ambulastis: horrende et celeriter apparebit vobis, quoniam indicium durissimum his qui praesunt fiet. Exiguis enim conceditur misericordia, potentes autem potenter tormenta patientur. Non enim personas subtrahet, qui est omnium dominator: nec reverebitur magnitudinem cuiusquam, quoniam pusillum et magnum ipse fecit et aequaliter cura est illi pro omnibus. Fortioribus autem fortior instat cruciatio." Gildas is quoting here from Wisdom 6.2-9.
} 
While Gildas relies mostly on biblical models, he also invokes a figure from Britain's recent past: Ambrosius Aurelianus. Using famous and semi-legendary cultural figures as exempla helped supplement the biblical models by generating a sense of ethnic pride. As I demonstrate in the next chapter, this aspect was especially important to Bede in his attempt to motivate King Ceolwulf. Ambrosius was a Romano-British war leader who fought against the invading Anglo-Saxons sometime between 460-480; according to tradition, he was regarded as a descendant of Emperor Aurelian (r. 270-75). ${ }^{49}$ Gildas describes Ambrosius as a heaven-sent leader to the broken Britons:

After a time, when the cruel plunderers had gone home, God gave strength to the survivors. Wretched people fled to them from all directions, as eagerly as bees to the beehive when a storm threatens, and begged wholeheartedly, 'burdening heaven with unnumbered prayers', that they should not be altogether destroyed. Their leader was Ambrosius Aurelianus, a gentleman who, perhaps alone of the Romans, had survived the shock of this notable storm: certainly his parents, who had worn the purple, were slain in it. His descendants in our day have become greatly inferior to their grandfather's excellence. Under him our people regained their strength, and challenged the victors to battle. The Lord assented, and the battle went their way. ${ }^{50}$

${ }^{49}$ Frank D. Reno, The Historic King Arthur: Authenticating the Celtic Hero of Post-Roman Britain (Jefferson: McFarland, 1996), 263. Peter Korrel, An Arthurian Triangle: A Study of the Origin, Development, and Characterization of Arthur, Guinevere, and Modred (Leiden: E.J. Brill, 1984), 23. ${ }^{50}$ Gildas, The Ruin of Britain, 25.2-3. Gildas. Gildae de Excidio Britanniae, 25, p. 60: "Tempore igitur interveniente aliquanto, cum recessissent domum crudelissimi praedones, roborante Deo reliquiae, quibus confugiunt undique de diversis locis miserrimi cives, tam avide quam apes alvearii procella imminente, simul deprecantes eum toto corde et, ut dicitur, Innumeris onerantes aethera votis, ne ad internicionem usque delerentur, duce Ambrosio Aureliano viro modesto, qui solus forte Romanae gentis tantae tempestatis collisione, occisis in eadem parentibus purpura nimirum indutis, superfuerat, 
Ambrosius is portrayed here by Gildas as the last of the Roman leaders, and as the son of those who had "worn the purple." Gildas does not specifically name him as a king, but does associate him with the purple of the Roman Emperors, thus hinting at his attributed imperial ancestor. Regardless, Gildas positions him in a fashion very similar to David, as a divinely-given savior in a time of need. Again Gildas makes a connection between the piety of the people and the figure of the king, but presented in a different way. Earlier, in the case of David and Saul, Gildas highlighted how an entire people could be punished for the sins of one king. Here, as the entire people raise their voice "with unnumbered prayers," a heroic figure arises to lead them. In both cases what is made clear is that a king was not merely a man who happened to hold political power, as we might conceive it today. Rather, the king existed in a symbiotic relationship with the people: they could be punished for his sins and benefit from his virtue; but also, according to Gildas, the people received the king they deserved based upon their own piety. By using the British Ambrosius rather than a biblical figure, Gildas indicates that this sort of sacral leadership was not simply something of the past, but a role that could be fulfilled in the time in which Gildas was writing. By presenting a British leader as a mirror of the kingship of David, Gildas makes clear that he is presenting behavior that is to be emulated. Gildas is very critical of the leaders of his own time, noting that Ambrosius' “descendants in our day have become greatly inferior to their grandfather's excellence.” By negatively comparing them to Ambrosius, Gildas seeks to shame them into living up to the deeds of their ancestors.

cuius nunc temporibus nostris suboles magnopere avita bonitate degeneravit, vires capessunt, victores provocantes ad proelium: quis victoria domino annuente cessit." 


\section{Conclusion}

With both Eusebius and Gildas, a number of important points of Christian kingship theory are established. The ideal situation is to have a saintly emperor ruling over Christendom, like Constantine. Such a ruler should model his realm upon Christ enthroned. When a ruler is extraordinarily pious, as Eusebius's Constantine is, he forms a bridge between heaven and earth, and to some extent, creates a heavenly kingdom on earth by acting as the hand of God. Even in more dissolute times, such as in the chaos of Gildas's age, a king must first and foremost look to his own piety if he wishes to be a good leader. A Christian ruler does not have to be a Roman emperor to acquire the mystical position of king, in which he embodies the sins and virtues of his people. The king, then, has no "private" life or "private" spirituality. Even if he sins in secret, it can still bring down the judgment of God upon the entire people, as can be seen with Saul or David. However, the punishment on the people will be less than that of the king himself, who is held to a different standard. This gives quite a different understanding of the idea, quoted earlier from Ezekiel, that God "will have no respect of persons." In Gildas's view, this does not mean that God judges all equally, without concern for social rank. Rather, God seems to be very concerned with social rank, and especially the rank of king. Here, God's lack of "respect" for the king indicates that he is not awed by earthly power and will indeed judge such men. It is a warning to Christian rulers and a reassurance to the common people. But in the same passage, it is made clear that the average person does not exist on the same hierarchal level as kings, either physically or spiritually. Kings are not merely men who happen to have political power, but are rather those who directly participate in the management of the earthly kingdom, who have a relationship with God 
that exists apart from others. The king occupied a unique position in which he participated in and connected the spiritual and physical in a way different from any other members of society. Even after the clarification of the Three Estates, the king (and he alone) would exist outside of these estates, standing above them, while simultaneously encompassing all of them. ${ }^{51}$

As I have argued throughout this chapter, aside from laying the foundations of Christian kingship, both Eusebius and Gildas offer early examples of ecclesiastical advice literature that would influence later writers. Eusebius could in many ways be considered an apologist for Christian kingship. He laid the theological foundations, and despite their source in Platonic thought, this conception of sacral kingship saw no conflict in the theocratic kingship models of the Old Testament, which generally demonstrated what this sort of kingship would look like in action. Both Eusebius and Gildas accepted and embraced the concept of sacral kingship, and the notion that a king was responsible for the spiritual well-being of his people. In other words, the difference between a king and a secular leader such a $d u x$ was not merely one of magnitude, but of kind. This understanding can be seen in the fact that many Anglo-Saxon kings were venerated as saints, while ealdormen who performed similar deeds were passed over. ${ }^{52}$ While Constantine would remain a figure of emulation throughout the Middle Ages, Gildas promoted looking to the Old Testament for models of kingship, a practice that was embraced by many medieval ecclesiastics. Through Anglo-Saxon and Carolingian texts, there are numerous references to the kingship of Saul, David, and Solomon, and these

\footnotetext{
${ }^{51}$ Thomas D. Hill, “A Riddle on the Three Orders in the Collectanea Pseudo-Bedae?" Philological Quarterly 80, no. 3 (Summer 2001): 205-12.

${ }^{52}$ Damon, "Sanctifying Anglo-Saxon Ealdormen," 185-88. As Damon points out, this lack of sanctity for non-royal secular leaders such as Byrhtnoth promoted the path to sanctity that the Crusades offered.
} 
figures would serve as key models for both positive and negative behavior, as all three are at various times praised or criticized in the Old Testament itself. Over time, these Old Testament models would overshadow and replace Roman exemplars like Constantine in importance, ${ }^{53}$ and writers would learn to find local, native exempla that they could in turn associate with these Old Testament kings.

${ }^{53}$ Oakley, Kingship, 97. "The rite of royal anointing was suited admirably to promote such views, and along with its introduction into the Frankish realms went an intensification of the clerical habit of comparing the position and attributes of the Frankish monarchs with the sacral position and priestly attributes of the Old Testament kings, as well as with those of Moses and Melchizedek, king and priest. This development becomes most strikingly evident in the Carolingian era, when contemporaries were prone to portraying the Frankish kingdom as itself 'the kingdom of David.' During that period, too, the Frankish king, being like his Old Testament forebears the anointed of God, came to regard himself and was in turn so regarded by his people, as a new Moses, a new David, a new Solomon, a truly sacral monarch worthy of being greeted by the assembled clerics of his kingdom as nothing less than 'king and priest."' One reason Old Testament models became more prominent is that the Middle Ages saw the Roman Empire fragment into various Christian kingdoms and peoples who organized themselves along "tribal" kinship lines rather than the more civic cosmopolitanism of Rome. The Anglo-Saxons would likely have found the war-torn tribal world of David more comprehensible than the sprawling empire of Constantine. 


\section{CHAPTER 2}

\section{BEDE}

Today Bede is known primarily for his authorship of the Historia ecclesiastica gentis Anglorum $(H E)$ and is often thought of as an early historian. While the $H E$ is indeed a critical text for the historical period in question, Bede was not a historian in the modern sense. He had no concern for objectivity, as it would now be conceived. In fact, it is fairly clear that he made his biases known: he was writing a history of Christianity in Britain, a history that rested upon an understanding of God as the primary agent of that history. What is perhaps less clear is what his motivation was in writing such a work. As a monk, Bede was known during his own life and in the generations following as a religious writer who produced works on biblical exegesis and computus. He was wellknown by later writers, and it is estimated that around thirty-five other authors in AngloSaxon England are known to have either quoted Bede or else to use his works in their writing. ${ }^{1}$ This influence was especially felt during the tenth-century Benedictine Reform. ${ }^{2}$ Bede's status as a religious authority and his collective body of work both make the $H E$ stand out as something of an oddity. It is the only one of his works that concerned itself with so many secular figures and events, and despite the title of Historia Ecclesiastica, it gives a great amount of space to kings. It is also unique among his works in that it is

\footnotetext{
${ }^{1}$ Sharon M. Rowley, "Bede in Later Anglo-Saxon England." In The Cambridge Companion to Bede, edited by Scott DeGregorio, 216-28. Cambridge Companions to Literature. (Cambridge; New York: Cambridge University Press, 2010), 216.

${ }^{2}$ Rowley, "Bede in Later Anglo-Saxon England," 224.
} 
actually dedicated to a king, who reviewed an earlier version of the text. ${ }^{3}$ Other than kings, Bede rarely mentions laypeople (if indeed we wish to consider kings as lay). ${ }^{4} \mathrm{His}$ focus on kings is understandable, however, if we recognize that Bede saw kings as the key element in the salvation of a people. ${ }^{5}$ For his understanding of kingship, Bede principally drew upon Eusebius and the Old Testament. ${ }^{6}$ Both of these sources would have supported the idea of a social structure where ecclesiastics had an obligation to advise kings if they wished to look after the spiritual well-being of the people.

While Bede's $H E$ does indeed serve to outline the history of Christianity in England, it is in no way limited to that single purpose. The exegetical method of Scriptural interpretation that Bede and other ecclesiastics were trained in instilled the idea that a text could contain several layers of meaning. Traditionally, medieval interpretation of the Bible followed a fourfold method: historical, moral, Christological, and anagogical, a formulation that Bede himself embraced in his Biblical commentaries. ${ }^{7}$ The historical or literal interpretation connected the text with actual events; the moral interpretation connected the text with the moral teaching of the Church, the

${ }^{3}$ Bertram Colgrave and R. A. B Mynors, eds., Bede's Eccesiastical History of the English People (Oxford: Clarendon Press, 1969), Preface, 3.

${ }^{4}$ As I argued in Chapter I, and throughout this work, kings were generally considered to occupy a position above both ecclesiastics and lords, effectively existing within and above both spheres simultaneously.

${ }^{5}$ Kent G. Hare, "Heroes, Saints, and Martyrs: Holy Kingship from Bede to Ælfric.” Heroic Age 9 (October 2006): §2, http://www.heroicage.org/issues/9/hare.html.

${ }^{6}$ N. J. Higham, (Re-)Reading Bede: The Ecclesiastical History in Context (London: Routledge, 2006), 75; J.M. Wallace-Hadrill, Bede's Ecclesiastical History of the English People: A Historical Commentary. Oxford Medieval Texts. (Oxford: Oxford University Press, 1988), 2. Higham argues that Bede was primarily influenced by Eusebius, while Wallace-Hadrill considers the Old Testament as the most important source. I consider both works to be equally critical to Bede in terms of kingship. It is somewhat of a moot argument, as the models of kingship presented in the two sources are complimentary rather than conflicting. However, also see: Danuta Shanzer, "Bede's Style: A Neglected Historiographical Model for the Style of the Historia Ecclesiastica?" In Source of Wisdom: Old English and Early Medieval Latin Studies in Honour of Thomas D. Hill., edited by Charles D. Wright, Frederick M. Biggs, and Thomas N. Hall, 329-52. (Toronto: University of Toronto Press, 2007), 344, where she argues that in terms of style Bede was most indebted to Orosius and Rufinus.

${ }^{7}$ Conor O'Brien, Bede's Temple: An Image and Its Interpretation (Oxford: Oxford University Press, 2015), 27. 
Christological read the scripture as a prefiguration of Christ, and the anagogical (meaning a climb or ascent upwards) pertains to spiritual or heavenly matters. I argue that Bede wrote the $H E$ on at least two levels: on the historical or literal level, Bede is recording the development of Christianity in England; but on the moral level, Bede is writing a work of ecclesiastical advice literature in which he both criticizes rulers of his own time while also outlining a political framework that he wanted Anglo-Saxon rulers to adopt. ${ }^{8}$ This criticism is presented indirectly through exempla, which Bede intended to be read on both exegetical levels, so that he could write both literally and morally at once. This is in keeping with advice literature of the later Middle Ages, where authors would use exempla and metaphor to partially mask their critique.

\section{The Historia as Advice Literature for Ceolwulf}

While scholars have sometimes acknowledged the advisory nature of the $H E$, there has been little systematic analysis of the topic. James Campbell admits in an essay that the $H E$ "is in a degree a mirror for princes," ${ }^{9}$ but he is more concerned with Bede's terminology of Anglo-Saxon secular hierarchy. N.J. Higham, in his (Re-)Reading Bede, engages most closely with the question. He states that the $H E$ "has often been assumed to have been intended for a rather different audience from the remainder of Bede's work,

\footnotetext{
${ }^{8}$ Of course, Bede employed all four levels of interpretation throughout his works, including the $H E$. As the focus of this dissertation is political, I am less concerned with the Christological or anagogical implications of the text. In addition, as O'Brien, Bede's Temple, 28-29 makes clear, Bede did not systematically apply the four levels of interpretation to every Biblical verse, so there is no reason to conclude that this would be the case in the $H E$ either.

${ }^{9}$ Campbell, "Bede's Reges and Principes," 85 . Campbell concedes that Bede's work sought to "edify" on the issue of kingship, but also states that the $H E$ "was written for the purposes which do not conform to all the needs of our curiosity." Campbell' does not make clear his thoughts on the relationship between Bede's $H E$ and advice literature, as he quickly moves on to consider the various terms that Bede uses to describe rulers.
} 
owing to its unique dedication to a secular figure," but then states that "we must be wary as to how to interpret this distinction." ${ }^{\prime 10}$ Higham rejects the suggestion that Bede saw Ceolwulf as his audience, as he considers it unlikely that the king was literate. ${ }^{11} \mathrm{He}$ concludes that "Without further evidence, it seems inadvisable to suppose that the Ecclesiastical History can have reached a very different primary audience from that of Bede's biblical commentaries without considerable mediation by the clergy in the form of translation and oral transmission." 12 There are two issues with Higham's position. First, we do not know whether Ceolwulf was literate or not. While it was not common for laypeople to be able to read Latin during this time, Ceolwulf was an extremely monkish king who seems to have leaned towards monasticism his entire life. In fact, as will be seen, his monkishness is one of Bede's principal complaints about Ceolwulf. Second, even if we assume Ceolwulf was illiterate, he still could have been the audience, and still could have been influenced by the work, even through the "mediation" that Higham notes. In fact, it may be the case that Bede intended in the first place to influence and advise Ceolwulf through the medium of other ecclesiastics. As I argue throughout this dissertation, ecclesiastics commonly saw their advisory role to kings as an essential function of their office. While my research focuses, out of necessity, on those written records we have, post-conversion Anglo-Saxon kings were always advised by ecclesiastical figures. These figures could have understood Bede's moral message in his work and conveyed them to the king.

In addition, the dedication itself reveals that it was not simply a case of Bede

\footnotetext{
${ }^{10}$ Higham, (Re-)Reading Bede, 41.

${ }^{11}$ Higham, (Re-)Reading Bede, 41-42.

${ }^{12}$ Higham, (Re-)Reading Bede, 44.
} 
tacking on the name of a royal patron, since Ceolwulf is described as being quite engaged with the text. Bede states:

Your Majesty has asked to see the History of the English Church and Nation which I have lately published. It was with pleasure, sire, that I submitted it for your perusal and criticism on a former occasion; and with pleasure I now send it once again, for copying and fuller study, as time may permit. I gladly acknowledge the unfeigned enthusiasm with which, not content merely to lend an attentive ear to hear the words of Holy Scripture, you devote yourself to learn the sayings and doings of the men of old, and more especially the famous men of our own race. ${ }^{13}$

Bede looks for the king to approve and commend his work [probandum]. The word probo indicates approval and sanction of a deed done. Bede uses the word probo a total of seventeen times in the entire text, where the word often takes on a religious meaning, as though there were a divine sanction of the deed in question. For instance, Bede uses probo to describe St. Aidan, who proved himself worthy [probabatur] of being King Oswald's bishop to both the king and those elders in attendance, in contrast to the priest who had come before him. ${ }^{14}$ In the case of both Aidan and Bede, we have a situation in which a priest is seeking a Northumbrian king's approval and sanction of his spiritual work. In recounting this event, Bede is showing precedence for his own actions. Another instance of Bede's use of probo occurs when a monk named Baduthegn, who was

\footnotetext{
${ }^{13}$ Colgrave and Mynors, Bede's Ecclesiastical History, Preface, p. 2-3: "Historiam gentis Anglorum ecclesiasticam, quam nuper edideram, libentissime tibi desideranti, rex, et prius ad legendum ac probandum transmisi, et nunc ad transcribendum ac plenius ex tempore meditandum retransmitto; satisque studium tuae sinceritatis amplector, quo non solum audiendis scripturae sanctae uerbis aurem sedulus accommodas uerum etiam noscendis priorum gestis siue dictis, et maxime nostrae gentis uirorum inlustrium, curam uigilanter inpendis."

${ }^{14}$ Colgrave and Mynors, Bede's Ecclesiastical History, iii.5, p. 228.
} 
suffering from a painful affliction, went to the tomb of Cuthbert to pray for healing. His prayers were answered and he was healed: "to the joy of them all he returned to the office which he had been accustomed to fulfil so faithfully, yet still more purified and chastened as though by a scourge" [quasi flagelo probante castigatior]. ${ }^{15}$ Here Baduthegn has received the approval of St. Cuthbert, who has acknowledged the monk's faith and piety through healing. Bede's use of probo in these contexts suggests that he is seeking the religious approval of the king of what he has written. As J.M. Wallace-Hadrill has argued, "This prefatory letter is not strictly a dedication but a submission to King Ceolwulf." ${ }^{16}$ It perhaps would strike some as strange that a priest and monk would seek the approval of a king in this fashion. It must be remembered that Ceolwulf possessed, according to Bede, a great "love of religion" and also that the king saw himself as a key partner in the nourishment of Christianity within Northumbria. ${ }^{17}$ Yet, as Frank Stenton noted, while Bede approved of the king's religious dedication, he "clearly mistrusted his political capacity," ${ }^{18}$ as Ceolwulf's reign was plagued by weakness and instability. ${ }^{19}$ This chaotic political situation provided a ready motivation for Bede's desire to influence the king's reign, as well as his hope that his voice would carry weight with the monarch.

Bede's narration of the exploits of previous Northumbrian kings was a rebuke to the somewhat illegitimate house of Ocging that ruled during 732, when Bede finished his Historia Ecclesiastica. As the land had been torn by political instability, the landscape must have looked rather bleak when compared to the glories of Northumbria's past.

\footnotetext{
${ }^{15}$ Colgrave and Mynors, Bede's Ecclesiastical History, iv.31, p. 446.

${ }^{16}$ Wallace-Hadrill, Bede's Ecclesiastical History, 1.

${ }^{17}$ Bede, Letter to Egbert, qtd in Higham, (Re-)Reading Bede, 42.

${ }^{18}$ Frank Stenton, Anglo-Saxon England (Oxford: Clarendon Press, 1971), 92.

${ }^{19}$ D.P. Kirby, "King Ceolwulf of Northumbria and the Historia Ecclesiastica." Studia Celtica 14-15 (1980): 168.
} 
During this time period there appears to have been several rival branches contending for the throne of Northumbria, and many eighth-century Northumbrian kings were murdered or deposed. ${ }^{20}$ During the time of Bede the throne was occupied by Ocging usurpers who had only a thin connection to the traditional dynasty. The royal house of Northumbria traced its descent from Ida, who in turn was traced back to Woden, ${ }^{21}$ the common mythical ancestor of all Anglo-Saxon royal lines. ${ }^{22}$

\begin{tabular}{|l|l|}
\hline \multicolumn{2}{|l|}{ Table 1: Kings of Northumbria and dates of reign } \\
\hline Aldfrith (685/6-705) & King descended from Ida \\
\hline Eadwulf (705/6) & Unknown ancestry, possible rival family branch \\
\hline Osred I (705/6-716) & Son of Aldfrith, Last king from main family line \\
\hline Coenred (716-718) & Conspirator against Osred \\
\hline Osric (718-729) & Conspirator against Osred \\
\hline Ceolwulf (729-737) & Coenred's Brother \\
\hline
\end{tabular}

As shown in Table 1, King Osred (d. 716) was the last ruler who could trace his descent directly back to Ida. The throne was usurped from him by Eadwulf, about whom little is known, but it is possible that his claim represented a rival branch of the family. ${ }^{23}$ Osred's reign was unique in that he was a minor when he came to the throne and the only known case of a Northumbrian minority. ${ }^{24}$ As York argues, "The elevation of a boy king to the

\footnotetext{
${ }^{20}$ Yorke, Kings and Kingdoms of Early Anglo-Saxon England, 89.

${ }^{21}$ Marsden, Northanhymbre Saga, 21-26.

${ }^{22}$ Essex was an exception to this. See: Sisam, "Anglo-Saxon Royal Genealogies," 326.

${ }^{23}$ Yorke, Kings and Kingdoms of Early Anglo-Saxon England, 89.

${ }^{24}$ Yorke, Kings and Kingdoms of Early Anglo-Saxon England, 88.
} 
throne represents a desperate attempt to retain power by those whose fortunes" were connected to the royal line. ${ }^{25}$ Despite these efforts, Osred was murdered shortly after turning eighteen and coming into full control of his kingdom. ${ }^{26}$ Following this, the land was ruled from 716 to 718 by Coenred, one of the conspirators against Osred, who claimed descent from one of Ida's concubines; this was the obscure Ocging branch of the family, whose lineages were rather questionable. ${ }^{27}$ In 718 , another conspirator took the throne, Osric, who managed to hold power for eleven years, appointing Ceolwulf as his successor before he died. ${ }^{28}$ Ceolwulf, to whom Bede addressed his preface, was therefore another Ocging, and the brother of the aforementioned Coenred. ${ }^{29}$ So even beyond Ceolwulf's political ability (or lack thereof), he and his family were in some sense usurpers who had not brought strength or stability to the realm. While Bede includes a rather warm greeting to Ceolwulf in his preface, one has to wonder at Bede's boldness in sending Ceolwulf the glorious exploits of kings like Edwin and Oswald, kings whose legitimacy and heroic deeds were unquestioned. ${ }^{30}$ In fact, there may be something of an insult lurking under the text of the $H E$, or at the very least a sharp rebuke. By recalling those "famous men" [inlustrium], Bede is by comparison showing the lack of good kingship by the Ocgings. ${ }^{31}$ Like other advice literature that would come after, Bede is using exempla to criticize and correct the behavior of current rulers. Speaking of the later

\footnotetext{
${ }^{25}$ Yorke, Kings and Kingdoms of Early Anglo-Saxon England, 87.

${ }^{26}$ Marsden, Northanhymbre Saga, 221.

${ }^{27}$ Marsden, Northanhymbre Saga, 223.

${ }^{28}$ Symeon of Durham called Osric "the son of King Aldfrith," and so he might have been the brother or half-brother of Osred. It's also possible he was the son of King Ealhfrith of Deira. It is impossible to be certain given the current evidence. Marsden, Northanhymbre Saga, 223.

${ }^{29}$ Marsden, Northanhymbre Saga, 223.

${ }^{30}$ Edwin was actually not descended from Ida, but did belong to the royal line of the Yffings, who ruled Deira before it was absorbed into Northumbria. The two branches were united through several marriages, and Oswald could trace his descent in both lines.

${ }^{31}$ Colgrave and Mynors, Bede's Ecclesiastical History, Preface, p. 2-3, n. 58.
} 
Middle Ages, Ferster noted, "The dangers of criticizing the king and his advisors encouraged a retreat to the safer territory of advice manuals, which lessened the risks of contemporary politics ... The mirrors for princes are not only more topical than they appear to be but also more critical of the powerful than we might expect." ${ }^{\prime 32}$ The only true difference between Bede and these later writers is that Bede is placing his advice within an ecclesiastical history, whereas later advice writers employed the outer form of the advice manual. But in both cases, the work is performing greater work than is immediately apparent. An examination of Bede will show, however, that his work is closer to an advice manual than has been acknowledged.

Bede states in the Preface that his goal is to use historical exempla in order to motivate others to follow the example shown. In doing so, he was using the cultural power of Anglo-Saxon kinship bonds to influence Ceolwulf and others. Bede writes:

Should history tell of good men and their good estate, the thoughtful listener is spurred on to imitate the good; should it record the evil ends of wicked men, no less effectually the devout and earnest listener or reader is kindled to eschew what is harmful and perverse, and himself with greater care pursue those things which he has learned to be good and pleasing in the sight of God. ${ }^{33}$

Ceolwulf, according to Bede, was quite interested in the "famous men" [inlustrium] of Northumbria's past, a word that can also mean "noble.” Ceolwulf, like other Anglo-Saxon

${ }^{32}$ Ferster, Fictions of Advice, 3.

${ }^{33}$ Colgrave and Mynors, Bede's Ecclesiastical History, Preface, p. 2-3. "Siue enim historia de bonis bona referat, ad imitandum bonum auditor sollicitus instigatur; seu mala commemoret de prauis, nihilominus religiosus ac pius auditor siue lector deuitando quod noxium est ac peruersum, ipse sollertius ad exsequenda ea quae bona ac Deo digna esse cognouerit, accenditur." 
kings, was concerned with living up to the deeds of his ancestors, especially those who were remembered in song and legend as heroes. ${ }^{34}$ As William Chaney observes, "As in modern society an individual tends to be identified by his occupation, in Germanic society he identified himself by his lineage." ${ }^{35}$ This can be seen in Beowulf's declaration when asked to identify himself: "We synt gumcynnes Geata leode ond Higelaces heorðgeneatas. Wæs min fæder folcum gecyped, æbele ordfruma, Ecgpeow haten” [We are men of the Geatish people and Hygelac's hearth-companions. My father was wellknown among folk, a noble commander named Ecgtheow]. ${ }^{36}$ The way that Beowulf entirely constructs his identity in terms of his ancestors demonstrates the cultural power of those who would recount history. In fact, the text of Beowulf itself and the fact that it was copied even in the late tenth century demonstrates the tremendous concern that the Anglo-Saxons had with their ancestors, and how this obsession with kinship shaped how they viewed themselves. Thus in many ways, Bede's work can be seen as very personal to Ceolwulf, and not only due to the dedication, as this was not unheard of: Martin of Braga sent his Formula vitae honestae to King Mir of the Sueves; and Isidore sent his De natura rerum to King Sisebut of the Visigoths. ${ }^{37}$ As Wallace-Hadrill notes, "To approach a Germanic king with a work of learning was thus not unusual. But Bede's work is a history that comes very near the experience and memories of Ceolwulf himself." ${ }^{38}$ Thus, because Bede worked with cultural memories that held great significance to Northumbrian monarchs, Bede had tremendous power in his hands to influence not only

\footnotetext{
${ }^{34}$ Hill, "The Christian Language and Theme of Beowulf," 200.

${ }^{35}$ Chaney, The Cult of Kingship in Anglo-Saxon England, 18.

${ }^{36}$ Klaeber, Beowulf, 1. 260-63. Old English translations are mine unless otherwise noted.

${ }^{37}$ Wallace-Hadrill, Bede's Ecclesiastical History, 2.

${ }^{38}$ Wallace-Hadrill, Bede's Ecclesiastical History, 2.
} 
the behavior of Ceolwulf and other Northumbrian rulers, but also other kings as well.

Bede, in desiring to influence aristocratic opinion, shaped his text appropriately in both language and content. As noted above and explored in detail below, Bede focused a great amount of attention on the heroic kings of Northumbria, which were Ceolwulf's ancestors and kin. And Bede indicates in his Preface that these are men whose deeds should be emulated. He praises Ceolwulf's "unfeigned enthusiasm" for both Scripture and "the sayings and doings of the men of old, and more especially the famous men of our own race. ${ }^{39}$ Again, Higham argues against taking Bede's praise of Ceolwulf's seriously: it is probably safer to read this portrayal [of Ceolwulf] by Bede primarily as rhetorical ... If Bede felt both his Ecclesiastical History and his Letter to Egbert needed royal support to further their respective aims, he could do little more than put the best gloss available on the ruler of the day in the hope that he could be induced to adopt the role of proactive, virtuous Christian king. ${ }^{40}$

I would agree with Higham here that Bede is using a bit of flattery, as practically all writers did when addressing a king. But it is unlikely that Bede fabricated the account of Ceolwulf offering criticism of an earlier draft. Even if illiterate, Bede notes how Ceolwulf lends a careful ear [aurem sedulus accommodas] to Scripture readings, and how he had a keen interest in the "famous men of our own race" [nostrae gentis uirorum inlustrium]. ${ }^{41}$

\footnotetext{
${ }^{39}$ Colgrave and Mynors, Bede's Ecclesiastical History, Preface, p. 2-3. Full passage as quoted earlier [n. 58]: "Historiam gentis Anglorum ecclesiasticam, quam nuper edideram, libentissime tibi desideranti, rex, et prius ad legendum ac probandum transmisi, et nunc ad transcribendum ac plenius ex tempore meditandum retransmitto; satisque studium tuae sinceritatis amplector, quo non solum audiendis scripturae sanctae uerbis aurem sedulus accommodas uerum etiam noscendis priorum gestis siue dictis, et maxime nostrae gentis uirorum inlustrium, curam uigilanter inpendis."

${ }^{40}$ Higham, (Re-)Reading Bede, 70.

${ }^{41}$ Colgrave and Mynors, Bede's Ecclesiastical History, Preface, 2-3.
} 
Again, flattery is one matter; inventing interests in subjects is quite another. There is no reason or evidence for doubting Bede here, and considering that the king would, at the very least, have read or heard the dedication, it seems much more likely that Bede is simply telling the truth, that the king had offered feedback on an earlier draft, was a pious Christian king, and was interested in the reign of kings before him.

In addition to this being the simplest explanation, there is something rather idiosyncratic about his praise of Ceolwulf, and evidential reasons exist to accept it as genuine. To begin with, it is much too specific to fit the mold of empty praise, which generally was abstract in the extreme. This form of empty praise was not unknown during the Middle Ages, and would develop into something of an art by the later medieval period. Compare Bede's specific praise to that offered by Stephen Scrope to Henry VI in the fifteenth century:

O ye highe and myghtifulle prince, king of Englande and of Fraunce, and alle ye other noble princes and other puissaunt lordes and nobles of divers astates olde or yong, of so auncien a stok and of so worthy a lineage, as of the noble Trojan is blode descendid, as it is auctorised and may appere by many croniclers and histories of noble doctours enacted and registred, that ye alonly have ever ben halden without note of errour or deformite of the law with the most puissaunt and of power throughe all regions cristen or hethen, haveng always under youre regencie and governaunce the habondaunce of noble men of chevalrie, passing all other landes after the quantite and afferaunt of youre roiaume $\ldots{ }^{42}$

${ }^{42}$ Scrope, Boke of Noblesse, 43. 
Scrope continues this language for some time. In contrast, we have some reason to believe that Bede had cause for his specific praise, and that Ceolwulf was both pious and learned. While his account should not be uncritically accepted, William of Malmesbury had a high estimation of Ceolwulf's intellect, and wrote that the king was "possessed of a depth of literature. ${ }^{{ }^{43}}$ Concerning Ceolwulf's piety, the king granted several estates to the monastery of Lindisfarne before retiring there, where he lived as an ordinary monk. ${ }^{44}$ According to tradition, he followed the "milk and water" diet at Lindisfarne, which were the only fluids allowed according to the discipline of the monastery, and he was venerated as a saint after his death. ${ }^{45}$ Therefore, there are strong reasons to accept that Ceolwulf was serious about his religious convictions over the argument that Bede was using empty flattery. I argue that, just as Bede carefully tailored his Preface for a royal audience, he also tailored the entire work with a royal audience in mind. This is the reason why he vetted an earlier draft through Ceolwulf, why he selected so many exempla that would appeal to a king, and also explains why so many later rulers, such as Charlemagne and Alfred, would consider the $H E$ an important work. ${ }^{46}$

\section{Bede as Royal Advisor}

In a sense, it was natural for Bede to write about kingship, considering his own connections to the court and aristocracy. Monks did not typically have the reach or number of connections that Bede had, and this could be partially attributed to his own

${ }^{43}$ Marsden, Northanhymbre Saga, 224.

${ }^{44}$ Kirby, "King Ceolwulf of Northumbria and the Historia Ecclesiastica," 169.

${ }^{45}$ Kirby, "King Ceolwulf of Northumbria and the Historia Ecclesiastica," 169. In the ninth century, Ceolwulf's relics were moved to Norham "with those of St. Cuthbert and in part eventually to Durham."

${ }^{46}$ Westgard, "Bede and the Continent in the Carolingian Age and Beyond," 206 
kinship lines. While monastics, in theory, were supposed to renounce family connections and the outside world, this often was not the case. Bede, as an Anglo-Saxon man, was himself a part of a culture that valued and used kinship in ways that overshadowed other societal connections. While we do not know for certain who Bede's father was, James Campbell has made a convincing argument for Bede's aristocratic blood:

Bede moved in the highest company. He sent a draft of his Ecclesiastical History to King Ceolwulf for comment. He was on visiting terms with Ceolwulf's cousin, Egbert, bishop (soon archbishop) of York; and it was to Egbert that he wrote the letter of detailed reformist rebuke which gives his harsh judgment on the Northumbrian Church. These relationships suggest that he was near to a circle of men in power. The suggestion is reinforced by the late eight-century genealogical king-list for the kingdom of Lindsey. It has a man called Biscop succeeding his father Beda at some time in the eighth century ... this document hints seriously that these were names current in a very grand family, one to which Bede and Benedict Biscop both belonged. ${ }^{47}$

Campbell's position is (as he himself admits) ultimately unprovable. One major objection one might have is that if Bede had been of aristocratic blood, he would have been made an abbot. While this is reasonable, it is also possible Bede refused such a position out of a desire to remain with his beloved abbot Ceolfrith, or to focus his attention on writing. Regardless of his lineage, Bede had influence far beyond the average monk and was

\footnotetext{
${ }^{47}$ Campbell, "Secular and Political Contexts," 25. In Colgrave and Mynors, Bede's Ecclesiastical History, v.24, p. 566-71, Bede gives us a short biographical sketch of himself, but does not state who his father is.
} 
comfortable rebuking a bishop or advising a king. While Bede may have lived a seemingly cloistered and reclusive life, through his correspondence and other writings he was very much enmeshed within the politics (both ecclesiastic and secular) of his day, and had both the family connections and intelligence to exert his influence. ${ }^{48}$ Bede was not simply tracing out the history of England for antiquarian purposes, but rather was using history (much as he used the Old Testament) as a model for influencing events in his own time. In both cases, Bede selected exempla to demonstrate either good or bad behavior. In this sense, writing advice literature for a king was in some ways similar to constructing a moral sermon or holding up the behavior of a saint for emulation. The primary difference was that while correct Christian behavior for a layman was generally agreed upon by Bede's time, the exact nature and role of Christian kingship was still undergoing development. In emphasizing and praising certain kings over others, Bede was making conscious decisions about what that kingship should look like.

Aside from Northumbrian history, Bede looked to the Old Testament for models of good kingship. Part of the appeal for Bede would have been the authoritative nature of Scripture. Perhaps equally important, was the way that Bede understood the relationship and parallels between the Anglo-Saxons and the Israelites. As Judith McClure argues, "Bede had learned from Gregory a view of his own people as a primitive race resembling the Israelites, who had to be led gradually to the fullness of Christian faith, just as God had taught his chosen people with gentleness in the Old Testament." ${ }^{, 49}$ In addition, Nicholas Howe's examination of Old English poetry shows that the Anglo-Saxons

\footnotetext{
${ }^{48}$ George Hardin Brown, A Companion to Bede (Woodbridge: Boydell Press, 2009), 2.

${ }^{49}$ McClure, "Bede's Old Testament Kings," 76.
} 
continually conflated their own migration myth with that of the Israelites. ${ }^{50}$ One example of this motif is the parallels drawn between the Israelites' crossing of the Rea Sea and the Anglo-Saxons' crossing of the North Sea in order to reach Britain. ${ }^{51}$ By comparison, the New Testament offers an unfamiliar situation to the Anglo-Saxons, that of an oppressed religious minority existing within a pagan empire. In addition, the New Testament is lacking in models of Christian government or kingship. The rulers encountered there, such as Pilate and Herod, are presented as foils to Christ, as obstacles to overcome. Overwhelmingly, the New Testament presents government as something in opposition to faith. But the Old Testament's extensive histories and chronicles featured kings who ruled in the name of God, and who were often advised and prodded by prophets and other religious figures. The presence of these religious figures also helped to cement Bede's own validity in criticizing and commenting upon secular authorities. If the Israelites were a prefiguration for the Anglo-Saxons, then the prophet Samuel could serve as a prefiguration for ecclesiastics like Bede who sought to advise a king.

Bede identified with Samuel in several ways, and the book of Samuel was of special importance to him. ${ }^{52}$ It is in his commentary on Samuel that he includes one of his most personal statements, his sadness at the departure of Abbot Ceolfrith:

Having completed the third book of the Commentary on Samuel, I thought that I would rest a while, and, after recovering in that way my delight in study and writing, proceed to take in hand the fourth. But that rest—if

\footnotetext{
${ }^{50}$ Nicholas Howe, Migration and Mythmaking in Anglo-Saxon England (Notre Dame: University of Notre Dame Press, 2001).

${ }^{51}$ Howe, Migration and Mythmaking in Anglo-Saxon England, 74. As Howe further notes on p. 74-75, the author of the Old English Exodus intentionally avoids any Latinisms in his adaptation, choosing to create new compounds instead, because "He understood that a Latin-tinged diction would . . . weaken the native meaning of the poem."

${ }^{52}$ Brown, "Bede's Life in Context," 9.
} 
sudden anguish of mind can be called rest—has turned out much longer than I had intended owing to the sudden change of circumstances brought about by the departure of my most reverend Abbot; who after long devotion to the care of his monastery, suddenly determined to go to Rome, and to breathe his last breath amid the localities sanctified by the bodies of the blessed Apostles and Martyrs of Christ, thus causing no little consternation to those committed to his charge, the greater because it was unexpected. But just as God, when He removed the aged Moses, appointed Joshua to the leadership, and ordained Eleazar to the priesthood in place of his father Aaron ... ${ }^{53}$

Here Bede slips into his own life and his own emotions while working on Samuel, a figure whose life reflected his own in so many ways. At the end of the passage he begins making comparisons to other Old Testament figures as well, demonstrating again the seamlessness in which he moved between Old Testament narratives and the narrative of his own life. As Michelle Brown has pointed out, this passage "reveals that he harboured a telling personal affinity with Samuel, the prophet-priest, who anointed Saul and David and established the sacral role of kingship mediated through, and regulated by, the

${ }^{53}$ Bede. In Primam Partem Samuhelis Libri, 212: "Tertio in beatum Samuhelem completo uolumine putabam me aliquamdiu reparata per quietem meditandi uel scribendi uoluptate sic demum ad inchoationem quarti manum esse missurum. Verum haec eadem mihi quies, si tamen quies est inopinata mentis anxietas, prolixior multo quam decreueram noua circumstantium rerum mutatione prouenit maxime discessu abbatis mei reuerendissimi qui post longam monasterialis curae obseruantiam subitus Romam adire atque inter loca beatorum apostolorum ac martyrum Christi corporibus sacra extremum senex halitum reddere disponendo non parua commissorum sibi animos et eo maiore quo improuisa conturbatione stupefecit. Sed qui Moysis longaeuo ab humanis rebus tollendo Iesum Naue in ducatum qui Eleazarum in sacerdotium Aaron patri substituit ..." As of this writing there is no full translation of Bede's commentary on Samuel, but George Hardin Brown, A Companion to Bede, 47, n. 66, has indicated that he is currently working on one. The small passage quoted above was translated by Plummer, Baedae: opera historica, I, pp. xv-xvi. 
priesthood." ${ }^{54}$ The parallels between Bede and Samuel, and the "personal affinity" he felt would have strongly recommended Samuel as a model of ecclesiastical advisor. Like Samuel, Bede was a religious figure who sought to shape the political landscape around himself. Bede's passage, with his references to Moses and other figures, also reveals that even in moments of painful personal emotion, Bede ordered and saw his life through Old Testament examples. His relationship to Old Testament narrative was not merely "professional," as it were; it ordered his worldview and emotional climate.

There were many parallels between the life of Samuel and that of Bede, providing further reasons why Bede would have identified with the prophet and seen him as a model of ecclesiastical advisor. Despite his networks of influence, Bede still existed in an isolated, cloistered state. He was born on land owned by the Wearmouth-Jarrow monastery, given to said monastery as a child, and remained there for the rest of his life, devoting himself to studying Scripture. ${ }^{55}$ Like Bede, Samuel was given by his parents to religious life at a young age and would dedicate his entire life to the priesthood. ${ }^{56}$ After Samuel declares Saul to be the king, he sets about putting down in writing what the nature of kingship should look like: "And Samuel told the people the law of the kingdom, and wrote it in a book, and laid it up before the Lord." ${ }^{57}$ Here Douay-Rheims translates legem regni as "law of the kingdom," but it could also be taken to mean something like "the law/principles of royal power." The New English Bible rather loosely translates the passage: "Samuel then explained to the people the nature of a king." ${ }^{58}$ This reading

\footnotetext{
${ }^{54}$ Brown, "Bede's Life in Context," 9.

${ }^{55}$ Brown, "Bede's life in Context," 5-6.

${ }^{56}$ I Samuel 1.21-25.

${ }^{57}$ I Samuel 10.25. "Locutus est autem Samuel ad populum legem regni, et scripsit in libro, et reposuit coram Domino."

${ }^{58}$ Ackroyd, The First Book of Samuel, 87-88. Ackroyd links the verse to the warnings that Samuel gave to the people in I Samuel 8.9.
} 
makes sense in that the situation in which the verse occurs is right after Saul has been acclaimed king and Samuel is moving into an advisory position. ${ }^{59}$ Thus, I propose that Samuel is writing a document on kingship, for the sake of the king. In other words, it can be seen as an early version of advice literature, given directly from a priest to a king. To add another layer, the author/compiler of Samuel might himself have been a scribe in the court of Solomon, working to explain the history of monarchy in Israel. ${ }^{60}$ If so, then the purpose of I Samuel itself could be seen as advice literature as well, as the compiler of I Samuel created a theological meditation on kingship that influenced others for centuries. $^{61}$

The political organization of Israel's kingship had a number of parallels to that of the Anglo-Saxons, so that it was no great ideological leap for Bede to apply what he saw in the Old Testament to his own situation. This would not have been true for the premonarchical period, however. The figure of the Judge in Israel was always somewhat advisory in that the Judge lacked "official authority," and basically led by persuading others. ${ }^{62}$ This was in contrast to the earlier period of theocracy under strong leaders like Moses and Joshua. ${ }^{63}$ The lack of true leadership during the Judges period can be encapsulated by the oft-repeated passage in the Book of Judges: "In those days there was

\footnotetext{
${ }^{59}$ Orr et al, "King, Kingdom," n.p.

${ }^{60}$ Ackroyd, The First Book of Samuel, 6.

${ }^{61}$ One potential problem with this reading is that there are, according to McKane, two contradictory ideologies present in the books of Samuel. The pro-monarchical strand (I Samuel 9.1-10.16) views the monarchy as divinely appointed in order to save Israel from the Philistines; the anti-monarchical strand (I Samuel 8) sees the emergence of kingship as an abandonment of the "primitive faith and a rejection of the kingship of Yahweh" (McKane, I \& II Samuel, 22). However, it is possible that a scribe working under a king uncritically incorporated earlier versions into his text, some of which conflict with his overall theme (Klein, "Samuel, Books of," 315).

${ }^{62}$ Orr et al, "King, Kingdom," n.p.

${ }^{63}$ Orr et al, "King, Kingdom," n.p.
} 
no king in Israel, but every one did that which seemed right to himself." ${ }^{\prime 64}$ Therefore, as the last of the Judges, Samuel's investiture of Saul relies upon his religious rather than secular authority. Thus, Samuel empowers Saul's kingship with anointing and confirms it through the casting of the holy lot. ${ }^{65}$ In this passage Bede is presented with a Biblical model of kingship in which the priest grants religious confirmation of the king and provides him with guidelines of conduct. The fact that Samuel "laid [the book] up before the Lord (reposuit coram Domino) emphasizes the fact that the behavior of kings was ultimately determined by God, who would presumably speak through his priest, in this case Samuel. Later, when Saul does not obey the commandments of God, it is Samuel who declares to him that his line will not continue the kingship. ${ }^{66}$ The king of Israel did not have unlimited authority; he "was responsible to Yahweh," and "his authority was more or less limited on the religious side by the prophets, the representatives of Yahweh, and in the political sphere by the 'elders,' the representatives of the people, though as king he stood above all. ${ }^{\prime 67}$ This final arrangement aligns closely to Anglo-Saxon kings, whose witan was made up of both ealdormenn and bishops. Thus Bede would have seen that ecclesiastics had a duty to ensure that their king's behavior stayed in line with the will of God and to serve as God's mouthpiece when needed. ${ }^{68}$ As noted earlier, Bede identified with Samuel both intellectually and emotionally. The fact that Samuel functions most prominently as an advisor to kings in a climate similar to that of Anglo-Saxon England would have encouraged him to act in a similar manner. Samuel was a prophet, but saw it

\footnotetext{
${ }^{64}$ Judges 17.6. "In diebus illis non erat rex in Israel, sed unusquisque quod sibi rectum videbatur, hoc faciebat."

${ }^{65}$ I Samuel 10.1-24.

${ }^{66}$ I Samuel 13.9-14.

${ }^{67}$ Orr et al, "King, Kingdom," n.p.

${ }^{68}$ This model of prophet and king is a recurring theme in the Old Testament, especially in the case of the later prophets
} 
as his duty to police the behavior of kings. Bede, who in the latter part of his life was increasingly concerned about the state of affairs in Northumbria, would have felt he had a moral imperative to become involved in secular affairs through the form of advice. ${ }^{69}$

\section{Old Testament Kingship Models}

Beyond identifying with Samuel himself, Bede learned from I and II Samuel that military strength was the most fundamental basis of kingship. ${ }^{70}$ As I and II Samuel emphasize repeatedly, a king was, before all else, the warleader of his people. The story of David's rise to kingship is "likely to be the one most central to any understanding of the assumptions and perceptions underpinning Bede's historical narrative."71 This is especially true when it comes to Bede's conception of kingship, because the books of Samuel are above all a theological meditation upon kingship and its relation to God, exemplified through a Davidian dynasty that secured its position on the battlefield. ${ }^{72}$ Even Saul, who in many aspects serves as a model of failed kingship, is praised early on for his ability to lead troops in the field:

And Saul having his kingdom established over Israel, fought against all his enemies round about, against Moab, and against the children of Ammon,

${ }^{69}$ Yorke, Kings and Kingdoms of Early Anglo-Saxon England, 22. Yorke notes that Bede was concerned both with the increasing unrest in Northumbria and the declining prestige of Northumbria in relation to other Anglo-Saxon kingdoms. Goffart, The Narrators of Barbarian History, 239, argues that Bede's letter to Egbert demonstrates political concern with greater Northumbria.

${ }^{70}$ There can be some confusion concerning the names of the Old Testament historical books. In the Hebrew, Samuel was originally one book, which was divided into, variously, I and II Kingdoms (Septuagint), I and II Kingdoms or Kings (Vulgate), I and II Samuel (most modern translations). Likewise, The Book of Kings was one book in Hebrew and was divided into III and IV Kingdoms (Septuagint), III and IV Kingdoms or Kings (Vulgate), I and II Kings (most modern translations). As Bede himself referred to the books as I and II Samuel [In Primam Partem Samuhelis Libri] I will follow his precedent here and use I and II Samuel.

${ }^{71}$ McClure, "Bede's Old Testament Kings," 77.

${ }^{72}$ Klein, "Samuel, books of," 312. 
and Edom, and the kings of Soba, and the Philistines; and whithersoever he turned himself, he overcame. And gathering together an army, he defeated Amalec, and delivered Israel from the hand of them that spoiled them ... And there was a great war against the Philistines all the days of Saul. For whomsoever Saul saw to be a valiant man, and fit for war, he took him to himself. ${ }^{73}$

Upon taking the mantle of kingship, Saul's first order of business is to go to war against the enemies of his people. The text lists out these enemies in detail to emphasize this early success, and Saul's ability to protect his people against despoilers. In a situation that finds parallels to the Anglo-Saxon comitatus or warband, Saul draws the valiant men [virum fortem] to himself. He surrounds himself first and foremost with those fit for war. In a similar fashion, David's leadership also emphasized his role as a warleader, providing a confirming example to that of Saul. Despite often being thought of as a pastoral shepherd, during the medieval period David was invariably depicted as a warrior on the battlefield; this was true even in regard to the Psalms. As Wallace-Hadrill points out, "The David of the Psalter is no Arcadian shepherd-boy. He is much more the David of the Book of Kings." ${ }^{74}$ Early medieval illuminations, for example, in the Stuttgart Psalter (c. 820) [see Appendix I] reveal scenes mostly involving "bloodshed, war, handto-hand combat, hunting, and judgment," while David himself "moves as an armed king protected by the massive hand of God; not only protected, but anointed and crowned by

\footnotetext{
${ }^{73}$ I Samuel 14.47-52. "Et Saul, confirmato regno super Israel, pugnabat per circuitum adversum omnes inimicos ejus, contra Moab, et filios Ammon, et Edom, et reges Soba, et Philisthaeos: et quocumque se verterat, superabat. Congregatoque exercitu, percussit Amalec, et eruit Israel de manu vastatorum ejus ... Erat autem bellum potens adversum Philisthaeos omnibus diebus Saul. Nam quemcumque viderat Saul virum fortem, et aptum ad praelium, sociabat eum sibi."

${ }^{74}$ Wallace-Hadrill, Early Germanic Kingship, 130.
} 
the same hand." ${ }^{75}$ David first proved his heroic valor as a young boy, against the giant Goliath. He invokes the name of God as he faces his foe: "And David said to the Philistine: Thou comest to me with a sword, and with a spear, and with a shield: but I come to thee in the name of the Lord of hosts, the God of the armies of Israel, which thou hast defied." ${ }^{76}$ Here David declares that God will determine the victor, and that Goliath's superior size and weaponry will not give him an advantage. Yet, as a king, David depends upon his army to secure his kingdom, just as Saul did. In a passage that echoes Saul's victory-list, the author carefully lists those whom David subjugates on the battlefield, and emphasizes his ability to take tribute from them:

And it came to pass after this that David defeated the Philistines, and brought them down, and David took the bridle of tribute out of the hand of the Philistines. And he defeated Moab, and measured them with a line, casting them down to the earth: and he measured with two lines, one to put to death, and one to save alive: and Moab was made to serve David under tribute. David defeated also Adarezer the son of Rohob king of Soba, when he went to extend his dominion over the river Euphrates. And David took from him a thousand and seven hundred horsemen, and twenty thousand footmen, and houghed all the chariot horses: and only reserved of them for one hundred chariots. And the Syrians of Damascus came to succour Adarezer the king of Soba: and David slew of the Syrians two and twenty thousand men. And David put garrisons in Syria of Damascus: and

\footnotetext{
${ }^{75}$ Wallace-Hadrill, Early Germanic Kingship, 130.

76 I Samuel 17.45. "Dixit autem David ad Philisthaeum: Tu venis ad me cum gladio, et hasta, et clypeo: ego autem venio ad te in nomine Domini exercituum, Dei agminum Israel, quibus exprobrasti."
} 
Syria served David under tribute: and the Lord preserved David in all his enterprises, whithersoever he went. ${ }^{77}$

David is here described in terms that would have been perfectly reasonable to an AngloSaxon. As a king, David is aggressively subjugating his neighbors and forcing tribute from them.

For eighth-century Anglo-Saxons, and in the depiction of Israel in Samuel, the measure of a good king was his ability to wage war and collect tribute. War and tribute formed the basis of kingly economics for much of the Anglo-Saxon period. ${ }^{78}$ The description of Scyld in the opening of Beowulf reflects this understanding:

Oft Scyld Scefing sceapena preatum, / monegum mægpum meodosetla ofteah, / egsode eorlas, syððan ærest wearð / feasceaft funden. He pæs frofre gebad: weox under wolcnum, weorðmyndum pah, / oð pæt him æghwylc para ymbsittendra / ofer hronrade hyran scolde, / gomban gyldan. Pæt wæs god cyning. ${ }^{79}$

[Often Scyld Scefing deprived many peoples of the mead benches, troops of enemies, terrified earls, since he was first found poor. He awaited

${ }^{77}$ II Samuel 8.1-6. "Factum est autem post haec, percussit David Philisthiim, et humiliavit eos, et tulit David frenum tributi de manu Philisthiim. Et percussit Moab, et mensus est eos funiculo, coaequans terrae: mensus est autem duos funiculos, unum ad occidendum, et unum ad vivificandum: factusque est Moab David serviens sub tributo. Et percussit David Adarezer filium Rohob regem Soba, quando profectus est ut dominaretur super flumen Euphraten. Et captis David ex parte ejus mille septingentis equitibus, et viginti millibus peditum, subnervavit omnes jugales curruum: dereliquit autem ex eis centum currus. Venit quoque Syria Damasci, ut praesidium ferret Adarezer regi Soba: et percussit David de Syria viginti duo millia virorum. Et posuit David praesidium in Syria Damasci: factaque est Syria David serviens sub tributo: servavitque Dominus David in omnibus ad quaecumque profectus est."

${ }^{78}$ This war and tribute economy was common throughout Germanic culture and can be observed with the Anglo-Saxons, the Vikings, and the Frankish kings on the Continent. This form of wealth could be enormous in the short-term, but did not provide long term benefits. Whenever a king died, this advantage would be lost. See: Yorke, Kings and Kingdoms of Early Anglo-Saxon England, 158-59.

${ }^{79}$ Klaeber, Beowulf, 1. 4-11. 
consolation for that: he flourished under the sky, prospered in glory, until each one of the neighboring peoples across the whale-road had to obey him, and pay tribute. That was a good king.]

The poet's unqualified attribution of god cyning is based solely on Scyld's ability to fight and collect tribute. A king who could fulfill these two tasks brought both safety and prosperity to his people. Without these two, a king would slowly weaken from lack of wealth, while his enemies would view him as a potential target. This is the situation presented in I Samuel with the endless raiding of the Philistines; it is also the situation after the death of Beowulf, where the Geatish people anticipate that enemies will begin attacking again, as they have lost their strong warleader. While Beowulf is a product of poetic fiction, it does reflect in many ways the realities that kings faced, especially during the earlier (pre-Alfredian) period. Campbell argues that the economic and political situation found in Beowulf closely mirror that found in Bede's England:

In short this world is one in which it is all-important for a king to give treasure, which includes arms. If he has treasure and is successful in war (these things feed one another) he can attract followers from other kingdoms, because noblemen are often on the move through hunger for reward or the necessities of exile. To keep giving he has to keep taking, and so adds feud to feud. No kingdom or king can hope for long success. When a great king grows ill or old or mean there are always enemies waiting at home and abroad. They seize their advantage and other kings rise, gaining the treasure, the men, and the glory. ${ }^{80}$

${ }^{80}$ Campbell, "Bede's Reges and Principes," 93. 
The political situation that Bede saw in Samuel was strikingly similar to that of his own Northumbria. While the poetic and religious parallels between the Israelites and the Anglo-Saxons have often been mentioned, not as much attention has been paid to the economic and political frameworks that the two peoples shared. ${ }^{81}$ These frameworks were not mere imaginative connections made by Anglo-Saxon writers, but realities rooted in a tribal, raiding environment. Eighth-century Northumbria was politically unstable in the extreme, and most kings during this period were either deposed or murdered ${ }^{82}$ This instability was in marked contrast to the prosperity and stability of seventh-century Northumbria, a stability that stemmed from the success that seventh-century Northumbrian kings had in battle, who became "immensely rich on the proceeds." ${ }^{" 83}$ The decline in Northumbria during Bede's time can be traced back to the defeat of King Ecgfrith, who ruled Northumbria between 670 and $685 .{ }^{84} \mathrm{He}$ died in the battle of Nechtansmere, which the Northumbrians also lost, resulting in a loss of tribute from both Celts and Anglo-Saxon neighbors ${ }^{85}$ Following this, Northumbria never really held a dominant position again. It makes sense then, that Bede had little patience for kings who did not fulfill their role as warleader, as it rapidly led to the decline of the entire people. The examples of Saul, David, and his own Northumbrian history all emphasized to Bede the necessity of king as warleader, and the similarities between Samuel's Israel and eighth-century Northumbria would have additionally validated Bede's use of the Old

\footnotetext{
${ }^{81}$ For example, Howe, Migration and Mythmaking focuses on literary motifs from the migration of the Hebrews into Israel and of the Anglo-Saxons into Britain, and Andrew P. Scheil, The Footsteps of Israel: Understanding Jews in Anglo-Saxon England. Ann Arbor [Mich.]: University of Michigan Press, 2004 compares the attitude Bede and others had towards the Israelites as opposed to medieval Jews.

${ }^{82}$ Yorke, Kings and Kingdoms of Early Anglo-Saxon England, 89.

${ }^{83}$ Yorke, Kings and Kingdoms of Early Anglo-Saxon England, 91.

${ }^{84}$ Yorke, Kings and Kingdoms of Early Anglo-Saxon England, 91.

${ }^{85}$ Yorke, Kings and Kingdoms of Early Anglo-Saxon England, 91.
} 
Testament as a model of effective kingship.

\section{Fthelfrith, the Pagan Hero}

By examining which kings Bede held up for praise or blame in the $H E$, we can begin to get a clear picture of the qualities he prized in a king. While the $H E$ includes numerous kings, certain figures stand out in the amount of attention and detail that Bede gives to them, and it is also often when writing about these figures that he breaks his customary reserve and includes snippets of commentary. I wish to focus on two figures from the $H E$ : an exemplary pagan king (Æthelfrith), and an exemplary Christian king (Oswald, Æthelfrith's son). Together they reveal what Bede considered essential to kings in general, and to Christian kings in particular.

Through his comparison of King Æthelfrith to Saul, Bede shows through Biblical example and ancestral history the imperative for a king to be aggressive in war. King Æthelfrith (r. 593-616) began as king of Bernicia, but he would later unite this region with the northern kingdom of Deira, thus becoming the first king of a united Northumbria. ${ }^{86}$ Æthelfrith was a pagan, as Northumbria would not be ruled by a Christian king until Edwin (ruled 616-633), who took the throne on Æthelfrith's death. Later, Æthelfrith's son Oswald would take the throne. Æthelfrith was an aggressive expansionist, and this made him no friends among the native Celts. In 603, King Áedán mac Gabráin of Dál Riata led a large force against Æthelfrith in an attempt to curb Northumbrian aggression. ${ }^{87}$ Despite having a smaller army, Æthelfrith won a devastating

\footnotetext{
${ }^{86}$ Kirby, The Earliest English Kings, 57. The title "Northumbria" was still relatively new during Bede's time (Higham, The Kingdom of Northumbria, 1).

${ }^{87}$ Colgrave and Mynors, Bede's Ecclesiastical History, i.34, p. 117.
} 
victory, obliterating King Áedán's forces in the Battle of Degsastan ${ }^{88}$ Bede relates that the defeat was so absolute that the Britons never dared to attack Northumbria again. ${ }^{89}$ One can detect Bede's pride as he recounts the deeds of Æthelfrith:

At this time Æthelfrith, a very brave king and most eager for glory, was ruling over the kingdom of Northumbria. He ravaged the Britons more extensively than any other English ruler. He might indeed be compared with Saul who was once king of Israel, but with this exception, that Æthelfrith was ignorant of the divine religion. For no ruler or king had subjected more land to the English race or settled it, having first either exterminated or conquered the natives. To him, in the character of Saul, could fittingly be applied the words which the patriarch said when he was blessing his son, 'Benjamin shall ravin as a wolf; in the morning he shall devour the prey and at night shall divide the spoil. ${ }^{190}$

It is notable that Bede does not criticize Æthelfrith for being "most eager for glory" [gloriae cupidissimus]. In fact, he seems to greatly praise Æthelfrith, while at the same time using the word gloria as a euphemism for what meant, in practical terms, preemptive war, killing, and destruction [exterminatis] of native peoples [indigenis]. He describes the situation, as Colgrave and Mynors tell us, "almost with enthusiasm," and

${ }^{88}$ Colgrave and Mynors, Bede's Ecclesiastical History, i.34, p. 117.

${ }^{89}$ Colgrave and Mynors, Bede's Ecclesiastical History, i.34, p. 117.

${ }^{90}$ Colgrave and Mynors, Bede's Ecclesiastical History, i.34, p. 116-17: "His temporibus regno Nordanhymbrorum praefuit rex fortissimus et gloriae cupidissimus Aedilfrid, qui plus omnibus Anglorum primatibus gentem uastauit Brettonum, ita ut Sauli quondam regi Israheliticae gentis conparandus uideretur, excepto dumtaxat hoc, quod diuinae erat religionis ignarus. Nemo enim in tribunis, nemo in regibus plures eorum terras, exterminatis uel subiugatis indigenis aut tributarias genti Anglorum aut habitabiles fecit. Cui merito poterat illud, quod benedicens filium patriarcha in personam Saulis dicebat, aptari: 'Beniamin lupis rapax; mane comedet praedam et uespere diuidet spolia.' Bede is quoting Gen. 49.27. 
that "the whole chapter may well have been influenced by some lost heroic poem celebrating the deeds of Æthelfrith." ${ }^{.91}$ While exterminatis might draw visions of pest control wiping out ants, the word does not necessarily indicate slaughter. It more often meant to "banish" or "expel." Nevertheless, Bede's praise presents us with a situation in which a Christian monk is celebrating a pagan warlord who subjugates his Christian neighbors through force, who aggressively pursued violence for the sake of gloria and spolia. As can be imagined, Æthelfrith was not viewed as heroic to the Celts he subjugated. In Celtic sources, Æthelfrith is seen as an infamous aggressor whose "death on the battlefield is listed ... among 'The Three Fortunate Assassinations of the Island of Britain."'92 Bede's praise of Æthelfrith seems incongruent if we assume that Bede's only purpose was to recount the development of Christianity in England. But if, alternatively, we consider the work as advice literature, Æthelfrith makes sense as a model of king as warleader. Bede gives Æthelfrith praise and depicts him as a very successful king. While there were elements about Æthelfrith that Bede could have criticized as a Christian monk, such as excessive pride or love of violence. Instead, Bede presents Æthelfrith as a figure to Ceolwulf as one of the "famous men of our own race," one who was worthy of emulation. ${ }^{93}$

For Bede, an essential part of kingship is aggressive warfare. In Bede's view, it was not merely a king's duty to fight defensively, but rather to aggressively subdue others, especially those of a different race and culture. With Æthelfrith, Bede champions

\footnotetext{
${ }^{91}$ Colgrave and Mynors, Bede's Ecclesiastical History, I.33, p. 116, n. 1. Higham, The Kingdom of Northumbria, 76, argues that Bede's source for Æthelfrith was likely "epic poetry of the Beowulf kind." This idea of a lost poem is rejected by Wallace-Hadrill, who suggests that a lost annal likely provided Bede with the material (Wallace-Hadrill, Bede's Ecclesiastical History, 47-48).

${ }^{92}$ Marsden, Northanhymbre Saga, 52.

${ }^{93}$ Colgrave and Mynors, Bede's Ecclesiastical History, Preface, p. 2-3: "maxime nostrae gentis uirorum inlustrium."
} 
his activities because he is a Northumbrian waging war on Celts. Contrary to my argument, Wallace-Hadrill would read Bede's account of Æthelfrith as being in unity with the greater story of the "missionary role" of the Anglo-Saxons rather than a "mere exaltation of military power. ${ }^{\prime 4}$ Of particular interest to Wallace-Hadrill is Bede's use of the Book of Genesis here: "Benjamin shall ravin as a wolf; in the morning he shall devour the prey and at night shall divide the spoil. ${ }^{95}$ Concerning this reference, WallaceHadrill offers the "accepted interpretation of Genesis that is applied to St. Paul: the wolf that devours in the morning by persecuting Christians distributes his prey in the evening by preaching the Gospel to the Gentiles. Æthelfrith's people were to behave in the same way." ${ }^{96}$ In other words, the pillage of Æthelfrith was simply part of God's plan to Christianize the island. This interpretation seems sensible, except this is not what Bede writes here. At no place in I.34 does Bede mention providence, or the sin of the Celts, or how Æthelfrith's actions led to missionary activity. As Marsden notes, "The battle of Degsastan had no evangelical significance ... Bede could have had no religious purpose in according Aethelfrith the stature which he implies"; his purpose here was rather to established Æthelfrith as the founder of Northumbria. ${ }^{97}$ Bede's reference to Genesis 49:27 is taken from a passage in which Jacob is prophesying and blessing his twelve sons upon his deathbed. The descendents of Benjamin will "ravin as a wolf." In other words, they will conquer and take spoils from others and divide them among themselves. Bede tells us that Jacob's words could also be applied to Saul ["in personam Saulis"], who was

\footnotetext{
${ }^{94}$ Wallace-Hadrill, Bede's Ecclesiastical History, 48.

${ }^{95}$ Bede, $H E$, I.34 [Gen. 49.27]: "Beniamin lupus rapax; mane comedet praedam et uespere diuidet spolia."

${ }^{96}$ Wallace-Hadrill, Bede's Ecclesiastical History, 48.

${ }^{97}$ Marsden, Northanhymbre Saga, 51.
} 
indeed of the tribe of Benjamin. ${ }^{98}$ As I demonstrated earlier, Bede approved of Saul's war leadership and his subjugation of enemy tribes. In terms of the fourfold interpretation of Scripture, Bede is interpreting Genesis 49:27 in a moral rather than Christological sense. He sees Biblical approval and moral sanction of a king who is a warleader. Bede's description of Æthelfrith's conquests in I.34, even if not taken from some older heroic material, certainly echoes that material in tone and content. Above all, I.34 is a celebration of the gloria gained by a Northumbrian king, how he excelled in warfare above all others, how he gained spolia from this and distributed them among his followers. It is a passage that celebrates the Northumbrian people and that could have been found in a story like Beowulf. The material is included, not because it was essential to the (re-)Christianization of Northumbria, but rather as a model of a king as warleader, who fought for his people. There is a certain irony in the fact that had Anglo-Saxon aggressors like Æthelfrith not existed, Britain would not have needed to rebuild its original Church in the first place. As always, however, Bede ignores such wrinkles in favor of his own kin loyalties, for such loyalties were also an essential aspect of Bede's conception of kingship.

Bede's celebration of Æthelfrith and other Northumbrian kings is based upon an understanding of kingship that is rooted in the Anglo-Saxon notion of kin. As discussed in the introduction, almost every legitimate Anglo-Saxon king claimed descent from Woden, ${ }^{99}$ a claim that continued to form part of the basis for kingship even after these kings formally accepted Christianity, so that royal families were invested in the deeds and

\footnotetext{
${ }^{98}$ I Samuel 9.21.

${ }^{99}$ Chaney, The Cult of Kingship in Anglo-Saxon England, 7; Sisam, "Anglo-Saxon Royal Genealogies," 326.
} 
histories of their pagan ancestors. ${ }^{100}$ The word cyning itself, and other Germanic words used to refer to the king, point to authority based in kinship, a connection that can still be seen in the closeness of the words king and kin. It is possible that the word cyning originally meant "son of the cyn or family," with cognates to be found in the Old Norse kunungr and the Old High German cuning. ${ }^{101}$ The connections between kinship and lordship can also be found in the Old English words ceðeling [man of royal blood] and ðeoden [chief of a tribe]. Further cognates can be found in the Burgundian hendinus [leader of the kind] and the Gothic kindins [leader of the race]. ${ }^{102}$ While the exact and original meanings of these words have been lost to us, they all indicate a close relationship between family and lordship, of authority based in blood and kinship relations. Although Woden would later be rewritten as a pagan king, the prestige of this descent remained important and helps in part to explain the Anglo-Saxon desire to maintain connections with a Germanic pagan past. William Chaney observes, "As in modern society an individual tends to be identified by his occupation, in Germanic society he identified himself by his lineage and by the lord whom he followed." ${ }^{103}$ This can be seen in Beowulf's declaration when asked to identify himself: "We synt gumcynnes Geata leode ond Higelaces heorðgeneatas. Wæs min fæder folcum gecyped, æpele ordfruma, Ecgpeow haten" [We are men of the Geatish people and Hygelac's hearth-companions. My father was well-known among folk, a noble commander named Ecgtheow]. ${ }^{104}$ Beowulf's identity is entirely rooted in both his people and his father, the

\footnotetext{
100 Thomas D. Hill, "The Christian Language and Theme of Beowulf." In Beowulf: A Verse Translation, Norton Critical Edition., 197-211. (New York: Norton, 2002), 200.

${ }^{101}$ Chaney, The Cult of Kingship in Anglo-Saxon England, 21.

${ }^{102}$ Chaney, The Cult of Kingship in Anglo-Saxon England, 21.

${ }^{103}$ Chaney, The Cult of Kingship in Anglo-Saxon England, 18.

${ }^{104}$ Klaeber, Beowulf, 1. 260-63.
} 
greater and smaller kin groups, respectively. Kinship relations did not merely give prestige; it was expected that people possessed the qualities of their ancestors. AngloSaxon kings were judged in terms of their ancestry, and royal blood meant the blood of heroes. By recalling the deeds of his ancestors, Bede was reminding Ceolwulf and other Northumbrian rulers of their bloodline, and therefore of their expected duties. Despite Bede's status as a major theologian and historian, he was still a Northumbrian, and the culture of Northumbria is inherent in his writings. ${ }^{105}$

Bede uses an Old Testament understanding of historical events that is rooted above all in kin relations. In describing the initial migration of the Saxons, Angles, and Jutes to Britain, he does so with no concern for the plight of the native people, who, it must be remembered, were Christians:

So here in Britain the just Judge ordained that the fire of their brutal conquerors should ravage all the neighbouring cities and countryside from the east to the western sea, and burn on, with no one to hinder it, until it covered almost the whole face of the doomed island. Public and private buildings fell in ruins, priests were everywhere slain at their altars, prelates and people alike perished by sword and fire regardless of rank, and there was no one left to bury those who had died a cruel death. ${ }^{106}$

${ }^{105}$ That Northumbrian monks were interested in heroic poetry and the deeds of their ancestors can be seen in Alcuin's famous line to the monks of Lindisfarne: "What has Ingeld to do with Christ?" [Quid Hinieldus cum Christo?] (Alcuin, Albini Epistolae, ed. E.L. Dummler, in Monumenta Germaniae Historica, Epistolae (Berlin, 1895), IV, letter 124, p. 183.). Here Alcuin was criticizing the monks for being too interested in native poetry. While it could be argued that the monks were engaged in mere entertainment, I would argue that it is nevertheless indicative of the interest such material held for monastics.

${ }^{106}$ Colgrave and Mynors, Bede's Ecclesiastical History, i.15, p. 52-53: "Sic enim et hic agente impio uictore, immo disponente iusto Iudice, proximas quasque ciuitates agrosque depopulans, ab orientali mari usque ad occidentale nullo prohibente suum continuauit incendium, totamque prope insulae pereuntis superficiem obtexit. Ruebant aedificia publica simul et priuata, passim sacerdotes inter altaria 
Here Bede casually describes the genocide of a Christian people without much comment. He does, it is true, read this event in terms of God's judgment, an understanding that he likely took from Gildas. But for Gildas, the Anglo-Saxons were an external scourge, and the British people were the newly-chosen people of God. The situation was seen as the assaults upon Israel by the Philistines. However, writing almost two-hundred years later, and as a Northumbrian, Bede did not view the British people as the chosen people of God. That role had been usurped by the Anglo-Saxons, along with almost the entire island, by right of conquest. Later Anglo-Saxon ecclesiastical writers such as Wulfstan would sound much like Gildas in describing the Vikings as a scourge against them for having sinned. So while Gildas and Bede do frame historical conquests in terms of providential history, they do so based upon an absolute loyalty to their own respective peoples and kin. For them, their own people are always the chosen people, and other peoples exist only as a target of conquest or as a goad towards piety. This framework of history was one learned from the Old Testament. And in all cases, this history was used to inspire in-group loyalty and to justify warfare against others. God always favors the conquerors. Bede's understanding of war and conquest is closely linked to his conception of king as warleader and helps explain why he promotes the kingship of both Æthelfrith and Oswald. By connecting conquest with the will of God, Bede is creating a theological framework in which the Anglo-Saxon penchant for war can be understood and made more palatable from a Christian viewpoint. ${ }^{107}$

trucidabantur, praesules cum populis sine ullo respectu honoris ferro pariter et flammis absumebantur, nec erat qui crudeliter interemtos sepulturae traderet."

${ }^{107}$ Within a much larger view, Bede's position was part of a growing concession towards violence within Christendom. This would later develop into an understanding of holy war, which was advocated by Wulfstan (see Chapter 4). While these holy wars were generally defensive, this idea would eventually evolve into the more aggressive concept of a crusade. In the motto of many crusaders (deus vult) one can detect the original seeds of providential conquest propounded by writers like Gildas and Bede. 


\section{Oswald, the Paragon of Christian Kingship}

While Bede certainly praises Æthelfrith as a warrior-king, his paganism limits his usefulness somewhat as a model of Christian kingship. But Anglo-Saxon understanding of blood meant that the son of a hero would likely have something heroic about himself as well. That Æthelfrith's son turned out to be both hero and Christian created a perfect model for Bede to uphold. It is useful to remember here that Æthelfrith and Oswald were distant relatives of King Ceolwulf as well. If Æthelfrith could pass his heroism down to Oswald, perhaps Bede hoped he could awaken a dormant heroism in Ceolwulf as well.

Oswald was something of a regional hero to Northumbria, and was celebrated as king, saint, and warleader. While Oswald's heroic status was sensible within the context of early Germanic kingship, he was a curious figure for sainthood, as he never renounced violence and died fighting on the battlefield. While warriors and soldiers had been sainted before, most military saints represented those who had served in the Roman Army and were martyred for their faith without offering resistance. ${ }^{108}$ Early medieval saints seem to follow the same pattern. St. Martin of Tours, perhaps one of the most well-known military saints, saw a conflict between being a Christian and performing military service. Upon leaving the military he declared, "I am the soldier of Christ: it is not lawful for me to fight." 109 John Edward Damon considers Martin an anti-hero as compared to the heroic figures of ancient Greece, as he represents "peaceful resistance, self-sacrifice, humility and spiritual integrity over armed combat, personal gain, pride in prowess and material

\footnotetext{
${ }^{108}$ Paul Halsall, ed., "Saints' Lives.” Internet Medieval Sourcebook (Fordham University Center for Medieval Studies, 1996), http://sourcebooks.fordham.edu/Halsall/sbook3.asp. There are numerous examples of these, including: Ss. Andrew the General, Callistratus, Christopher, Demetrius, Emeterius, Chelidonius, George, and others.

${ }^{109}$ Alexander Roberts, trans., Sulpitius Severus on the Life of St. Martin. In A Select Library of Nicene and Post-Nicene Fathers of the Christian Church, Vol. 11. Second Series. (New York, 1894), http://www.users.csbsju.edu/ eknuth/npnf2-11/sulpitiu/lifeofst.html\#4.
} 
victory." ${ }^{110}$ During Bede's time, there was a long-standing tradition that war and saintliness were not compatible. There had been, it is true, some accommodation made for "Just War" by Augustine of Hippo, and a sense that one could be a solider and a Christian. When Count Boniface, a Roman general and governor of Africa, wrote to Augustine in 418 indicating his desire to leave the military life for monasticism, Augustine reassured him that such a move was unnecessary:

Do not imagine that no one can please God while he is engaged in military service. Among such persons was the holy David, to whom God gave so great a testimony ... "But everyone hath his proper gift from God, one after this manner and another after that" [1 Cor 7:7]. Thus, some fight for you against invisible enemies by prayer, while you strive for them against visible barbarians by fighting... Think, then, of this first of all, when you are arming for the battle, that even your bodily strength is a gift of God. ${ }^{111}$

Yet despite the accommodation of war that Augustine had made possible, men who did not renounce violence were not generally venerated as saints. That Oswald was sanctified represented a mindset "diametrically opposed" to that upheld in the life of St. Martin: "By depicting death in battle as a form of martyrdom, early English writers took a crucial step toward the sanctification of war." ${ }^{112}$ Because Oswald represented a new form of

110 John Edward Damon, Soldier Saints and Holy Warriors: Warfare and Sanctity in the Literature of Early England. (Hampshire: Ashgate, 2003), 2. In many ways Sulpicius was writing a new form of hagiography himself, as Martin is the first non-martyred soldier to be regarded as a saint. Sulpicius seems to be aware of this problem, and significantly downplays Martin's military service. Even the space he does give seems dedicated to proving that Martin was not a soldier in the conventional sense, and he states that Martin was forced to join the military against his will.

${ }^{111}$ Augustine of Hippo, "Letter 189." In Nicene and Post-Nicene Fathers, First Series, edited by Philip Schaff, translated by J.G. Cunningham, Vol. 1. (Buffalo, NY: Christian Literature Publishing Co., 1887), http://www.newadvent.org/fathers/1102189.htm.

${ }^{112}$ Damon, Soldier Saints and Holy Warriors, 2. While Bede clearly regarded Oswald as a saint, I question whether or not Bede actually considered Oswald a martyr, as Bede gives Oswald's death only a short 
sanctity, Bede did not have purely Christian models of saints' lives to draw upon, and so like Augustine, looked instead to the Old Testament for examples of holy warrior kings. ${ }^{113}$

In describing the exploits of Oswald, Bede again shows an example of a heroic Northumbrian king who aggressively waged war for his people and was later sainted. After the death of King Edwin of Northumbria, who had converted to Christianity, his kingdom once again split into its two native divisions of Deira and Bernicia, ruled by separate kings. These two kings, Osric and Eanfrith, had been at least nominally Christian before their rise to power. "But no sooner had these two kings gained the sceptres of their earthly kingdom," Bede writes, "than they abjured and betrayed the mysteries of the heavenly kingdom to which they had been admitted and reverted to the filth of their former idolatry, thereby to be polluted and destroyed." 114 These two apostates were then conquered and put to death by the Christian King Cædwalla of Gwynedd, a nearby Celtic kingdom. While Bede judges this act "a just vengeance," he still criticizes Cædwalla for his "unrighteous violence" against them and labels him as a "savage tyrant" [tyrannus saeuiens $].{ }^{115}$ Here, as in other places, Bede sides with Northumbria over neighboring Celts without regard to religious status. He demonizes Cædwalla primarily for being a

amount of space when compared to the typical martyr's passion. However, see Catherine Cubitt, "Sites and Sanctity: Revisiting the Cult of Murdered and Martyred Anglo-Saxon Royal Saints." Early Medieval Europe 9, no. 1 (March 2000): 65. Cubitt points out that many of those after Bede did in fact consider Oswald to be a martyr, regardless of any intentions by Bede.

113 Thomas Head, "Hagiography." Hagiography Society. Accessed June 30, 2017. http://www.hagiographysociety.org/wp-content/uploads/2013/03/Head_Hagiography.pdf. As Head points out, most hagiographers sought to "subsume the particularity of a given saint's life into a generalized type of sanctity, such as the martyr, the virgin, or the holy bishop." While Oswald could in some sense be considered a martyr, he did not fit the passive acceptance of death generally seen in martyrs, which was ultimately modeled upon the Passion of Christ.

${ }^{114}$ Colgrave and Mynors, Bede's Ecclesiastical History, iii.1, p. 212-13.

${ }^{115}$ Colgrave and Mynors, Bede's Ecclesiastical History, iii.1, p. 212-13. 
Celt. This accords with Bede's loyalty to his own people, as noted earlier. It is important to recognize that Bede is castigating a Christian ruler who is overthrowing Northumbrian pagans, because it sets the stage for how he will be forced to describe Oswald when the exiled heir returned to claim his kingdom. Oswald is described in the most pious terms by Bede. Before the battle commenced, Oswald set up the sign of the holy cross and, on bended knees, prayed God to send heavenly aid to His worshippers in their dire need. In fact it is related that when a cross had been hastily made and the hole dug in which it was to stand, he seized the cross himself in the ardour of his faith, placed it in the hole, and held it upright with both hands until the soldiers had heaped up the earth and fixed it in position. Thereupon he raised his voice and called out to the whole army, 'Let us all kneel together and pray the almighty, everliving, and true God to defend us in His mercy from the proud and fierce enemy; for He knows that we are fighting in a just cause for the preservation of our whole race. ${ }^{\prime 116}$

Yet as Oswald falls to his knees in prayer, he cannot position himself as a Christian driving out heathens, a claim that could have been made by his enemy, Cædwalla. Instead, Oswald prays for "the preservation of our whole race" [pro salute gentis nostrae bella suscepimus]. Despite Cædwalla driving out and killing unbelievers and replacing

${ }^{116}$ Colgrave and Mynors, Bede's Ecclesiastical History, iii.2, p. 214-15: "Ostenditur autem usque hodie et in magna ueneratione habetur locus ille, ubi uenturus ad hanc pugnam Osuald signum sanctae crucis erexit, ac flexis genibus Deum deprecatus est, ut in tanta rerum necessitate suis cultoribus caelesti succurreret auxilio. Denique / fertur quia facta citato opere cruce, ac fouea praeparata in qua statui deberet, ipse fide feruens hanc arripuerit ac foueae inposuerit atque utraque manu erectam tenuerit, donec adgesto a militibus puluere terrae figeretur; et hoc facto, elata in altum uoce cuncto exercitui proclamauerit: 'Flectamus omnes genua, et Deum omnipotentem uiuum ac uerum in commune deprecemur, ut nos ab hoste superbo ac feroce sua miseratione defendat; scit enim ipse quia iusta pro salute gentis nostrae bella suscepimus."' 
them with his own Christian rule, Oswald is depicted as the hero who wages a just war for his people [iusta bella] because he is a Northumbrian and Cædwalla is shown to be a villain because he is a Celt. This iusta bella is in reality an ethnic, rather than religious war. Here Oswald fits most perfectly Bede's ideal Northumbrian king: a leader who fights, above all, for the wellbeing of his people [gens] while at the same time looking to and acknowledging God.

While a king's religious piety was important to Bede, it was a secondary concern. Bede did not approve of kings who became too monkish. The monastic life was not one that a king should aspire to. As noted earlier, a clear division of society into the Three Estates would not develop until Alfred. Still Bede saw a sharp distinction between a monk's duties and a king's, and did not appreciate those kings who did not stay within their role. ${ }^{117}$ There were several Anglo-Saxon kings who, abdicating from the throne, retired into monastic life. As Clare Stancliffe points out, the idea of a perfectly healthy king needing to retire to the monastery is practically unheard of on the Continent. ${ }^{118}$ She traces this phenomenon to Irish views of kingship. In Ireland, with its many petty kingdoms, a king was regarded simply as a layman and little more. As such, he was as likely to become a monk as anyone else. ${ }^{119}$ By contrast, Stancliffe argues, the Roman missionaries that were sent to England saw the king as instrumental in the salvation of the people. Extending this idea, Kent Hare argues that Bede "wrote about and promoted the Roman tradition of Christianity" and "took a dim view of kings forsaking their proper

\footnotetext{
${ }^{117}$ Hare, "Heroes, Saints, and Martyrs."

${ }^{118}$ Clare Stancliffe, "Kings Who Opted Out." In Ideal and Reality in Frankish and Anglo-Saxon Society: Studies Presented to J.M. Wallace-Hadrill, edited by Patrick Wormald. (Oxford: Basil Blackwell, 1983), 158.

${ }^{119}$ Stancliffe, "Kings Who Opted Out," 157-65, 172-4.
} 
place at the helm of their kingdom." ${ }^{120}$ This issue seems especially relevant in regards to King Ceolwulf, who at times seems more of a monk than a king, and who eventually joined a monastery himself. In fact, he spent much more of his life as a monk than as a king. ${ }^{121}$ During the early Anglo-Saxon period, there were competing ideas of the nature of kingship, but Bede's view promoted the idea of a kingship as a sacred office in itself, essential to the wellbeing of a people, and not one to be abandoned.

\section{Sigeberht, the Monk-King}

Just as he showed positive examples of kingship through exempla, Bede also includes a cautionary tale about a king who became a monk to demonstrate that such actions would not end well. Bede's account of King Sigeberht of East Anglia (r. 629-634) in III.18 demonstrates the tragic end of a king who abandoned his duties for religious life. In writing about Sigeberht, Bede describes him as "a good and religious man" (homo bonus ac religiosus) who sought to "establish a school where boys could be taught letters." ${ }^{122}$ Around 634 he resigned as king and entered a monastery, handing over his throne "to his kinsman Ecgric." ${ }^{123} \mathrm{He}$ then "received the tonsure and made it his business to fight instead for the heavenly kingdom." ${ }^{124}$ Later, when the country was under attack from the Mercian King Penda, the East Anglians wanted Sigeberht to come with them into battle "in order to inspire the army with confidence." ${ }^{125} \mathrm{He}$ denied their pleas so that they had to drag him to the battlefield unwillingly. Even then Sigeberht "refused to carry

\footnotetext{
${ }^{120}$ Hare, "Heroes, Saints, and Martyrs."

${ }^{121}$ Ceolwulf abdicated in 737 and remained in a monastery until his death in 764 . He reigned as king for only eight years but lived as a monk for twenty-seven years.

${ }^{122}$ Colgrave and Mynors, Bede's Ecclesiastical History, iii.18, p. 266-69.

${ }^{123}$ Colgrave and Mynors, Bede's Ecclesiastical History, iii.18, p. 269.

${ }^{124}$ Colgrave and Mynors, Bede's Ecclesiastical History, iii.18, p. 269.

${ }^{125}$ Colgrave and Mynors, Bede's Ecclesiastical History, iii.18, p. 269.
} 
anything but a staff in his hand. ${ }^{" 126}$ His ending is rather undramatically described by Bede: "He was killed together with King Ecgric, and the whole army was either slain or scattered by the heathen attacks." ${ }^{127}$ It is, in the words of Hare, "an admonitory piece showing what happens when a king forsakes his proper calling." ${ }^{128}$ I disagree with Wallace-Hadrill's assessment of the passage: "Bede records no miracle associated with [Sigeberht]; it was enough that he had chosen the monastic life despite his obvious success as king; and of this Bede strongly approves ... This account clearly illustrates Bede's indifference to the secular obligations of kingship." ${ }^{129}$ As Wallace-Hadrill does not explain wherein he sees Bede's approval, this assessment is puzzling. As he himself notes, Bede does not record a miracle associated with Sigeberht, as he does with those saints that he is upholding as examples, such as Oswald. He also describes Sigeberht's decision in a terse manner, without any positive commentary, as he does in so many other cases where he wishes to show his approval. The situation is further dampened by the fact that Sigeberht's side lost. As demonstrated earlier, success in battle was an important metric for Bede, as it demonstrated behavior in accordance with the will of God. That the East Anglians were slaughtered and that there is no mention of Sigeberht's veneration makes a strong case for Bede's disapproval. Thomas D. Hill, who analyzed the staff that Sigeberht carried in some detail, argues that the former king was likely trying to invoke the staff of Moses and with it the idea of combined religious and secular authority. ${ }^{130} \mathrm{He}$

\footnotetext{
${ }^{126}$ Colgrave and Mynors, Bede's Ecclesiastical History, iii.18, p. 269.

${ }^{127}$ Colgrave and Mynors, Bede's Ecclesiastical History, iii.18, p. 268-69.

${ }^{128}$ Kent Gregory Hare, "Christian Heroism and Holy War in Anglo-Saxon England.” Diss. (Louisiana State University and Agricultural \& Mechanical College, 1997), 265.

${ }^{129}$ Wallace-Hadrill, Bede's Ecclesiastical History, 111.

${ }^{130}$ Thomas D. Hill, “'Non Nisi Uirgam Tantum...in Manu': Sigeberht's Mosaic Aspirations (Bede, Historia Ecclesiastica III, 18)." Notes and Queries 53, no. 4 (December 2006): 394. For an analysis of the imagery of this staff in the Old English Exodus, see: Idem, "The Virga of Moses and the Old English Exodus." In Old English Literature in Context: Ten Essays, edited by John D. Niles, 57-65.
} 
concludes that "the very fact [Bede] includes these details implies that Bede was sceptical about any attempt to assimilate the monastic and the active life." ${ }^{131}$ Again, a king and a monk had different roles to fulfill in society. ${ }^{132}$ As Susan Ridyard writes, in regards to kings who abandoned their throne: "the single and crucial act upon which sanctity was founded represented not the renunciation of royal status but the fulfillment of royal duty." 133 In other words, one could be a holy king, but this was to be accomplished in the manner of Oswald rather than Sigeberht.

\section{Conclusion}

Bede saw the Anglo-Saxon people as a latter-day Israel, and so looked to the Old Testament for models of behavior. In I Samuel, both Saul and David are shown to be warleaders before all else, and Bede saw how God approved of an aggressive military policy from the kings of his chosen people. In ancient Israel, as in eighth-century Britain, only those kingdoms who pursued war had any chance of success. Part of this was due to a raiding economy, where successful kings would carry off wealth, which would be distributed amongst his followers. ${ }^{134}$ This behavior, often characterized as "ring giving" in Anglo-Saxon literature, created prestige for a king and attracted capable warriors. ${ }^{135}$

(Cambridge: D. S. Brewer; Rowman \& Littlefield, 1980).

${ }^{131}$ Hill, "Non Nisi Uirgam Tantum," 394.

${ }^{132}$ In the eleventh century, Ælfric of Eynsham also expressed a similar concern, and advised soliders against fasting when they would be needed to fight against invading Vikings. See: Derek Updegraff, "Style and Structure, Politics, and Preaching: The Lives of Saints and Other Alliterative Works by Ælfric of Eynsham.” Diss. (University of Missouri-Columbia, 2013), 27.

${ }^{133}$ Susan J. Ridyard, The Royal Saints of Anglo-Saxon England: A Study of WestSaxon and East Anglian Cults. Cambridge Studies in Medieval Life and Thought, 4th ser., 9. (Cambridge; New York: Cambridge University Press, 1988), 93.

${ }^{134}$ Yorke, Kings and Kingdoms of Early Anglo-Saxon England, 158-59.

${ }^{135}$ Campbell, "Bede's Reges and Principes," 93. As Campbell points out, the giving of treasure to followers was was still a crucial aspect of kingship during Bede's time. 
Bede approved of pious kings, but clearly demarcated this piety from that of monastics, and disapproved of kings who chose to express their religious convictions through entirely religious orders. Instead, Bede presents us with alternative path to piety for a king, one based in aggressive war and being gloriae cupidissimus. Unfortunately, Bede lived under a king who was more a Sigeberht than an Oswald. In 731, the same year Bede was finishing his Historia, Ceolwulf was captured and forcibly tonsured, a terrible humiliation for a king, but perhaps an act that was meant to prove a point. We know very little about Ceolwulf, but the evidence indicates that he was overly monkish. Being learned was not a bad quality in a king, but without a martial capacity it amounted to little worth during Bede's time. The fact that Ceolwulf was humiliated indicates a lack of control over his kingdom. There are no records showing him leading warriors against his enemies or being victorious in any way. There is an awkward silence in the $H E$ when it comes to Ceolwulf, as though he were something of an embarrassment. At the very least, he did nothing worth writing down. If he had, Bede would undoubtedly have done so.

Bede's $H E$ functions as advice literature through the promotion of native figures worthy of emulation. He uses the strong cultural force of kinship bonds to remind Ceolwulf and those who would follow him of the successful deeds of their ancestors. This rhetorical move is strengthened through Bede's constant reference to and comparison with kings of the Old Testament, such as Saul and David. In creating this picture of kingship, Bede is rarely explicit. His admission in the Preface, that he is presenting figures worthy of emulation, is a rare occurrence. As a writer, Bede is very reserved, and in cases like Sigeberht and even Ceolwulf, Bede's silence implies his disapproval. Likewise, he is not explicit in his theology of kingship, as Eusebius was. He 
is much closer to Gildas in the form he chooses to take. One pattern that seems to hold true for advice literature is when the writer is serving under a king who the ecclesiastic approves of, that king then becomes the subject of the work. This approach can be seen with Eusebius, Asser, and Einhard. When such exemplars are lacking, then the writer must search the past for exempla, as is the case with Gildas and Bede. Yet each case also demonstrates its own uniqueness. Gildas lived during a chaotic time of lawlessness, when normal political structures had broken down. Therefore he could be much more critical of the failures he saw around him. Bede, while disproving of the political leadership he saw in his time, still owed a certain amount of respect to Ceolwulf. Despite the king's shaky lineage, he was rightful king of Northumbria, and Bede demonstrates a certain familiarity with him. He indicates in he Preface that he regards Ceolwulf as "clear-sighted" (vigilantissimus) and that his work would thus serve as instruction for the king. ${ }^{136}$ It is clear that he hoped that the king would, perhaps through intellectual acceptance, see the superior model of kingship presented. He saw the great success that Oswald enjoyed, and wrote of how the king worked closely with Bishop Aidan and "humbly and gladly listened to the bishop's admonitions in all matters." ${ }^{137}$ Yet even if Ceolwulf was indeed vigilantissimus, he never managed to become the warleader Oswald was.

Ultimately, Bede's advice and exempla on how to be a successful king did not help Ceolwulf. In terms of advice literature, one must consider both the immediate and long term effects of the models presented. Bede's promotion of a strong military king who fought for his people would remain a lasting vision in Anglo-Saxon England. Bede's

\footnotetext{
${ }^{136}$ Colgrave and Mynors, Bede's Ecclesiastical History, Preface, p. 2-3.

${ }^{137}$ Colgrave and Mynors, Bede's Ecclesiastical History, III.3, p. 220-21: "eius admonitionibus humiliter ac libenter in omnibus auscultans."
} 
$H E$ continued to be read well into modern times, and his vision of kingship won out over the more Celtic notion of a king as a disposable secular layman. In more practical terms, history proved Bede right. Northumbria never again rose to power, or dominated the other Anglo-Saxon kingdoms. While part of this was due to the great wave of Vikings that arrived in the ninth century, it was also because of weak kingship that the Northumbrians were unable to resist. As I will argue in the next chapter, it is not a coincidence that the king who did finally turn the tide against the Vikings was one who embraced his role as warleader while also acknowledging the sacred role of a king. Alfred the Great was in many ways a king after the manner of Oswald, and a king that Bede would have undoubtedly approved of. 


\section{CHAPTER 3}

\section{ASSER}

In the nineteenth century, several statues were constructed of King Alfred. The statue at Winchester shows Alfred with his war gear, holding his sword aloft. The sword is held by the blade, point downward, so that the grip and crossguard form a cross. Here Alfred is represented as a holy warrior, as a king who is at home on the battlefield as he is at prayer. Another, at Wantage, depicts Alfred with an ax in one hand and a scroll in the other, emphasizing his status as a scholar-warrior. Both of these statues owe this vision of Alfred to Asser, who more than any ecclesiastic advisor before him, promoted the idea of a king who has mastered both wisdom and war.

If Bede was a famous ecclesiastic who wrote to a little-known king, then the opposite could be said about Asser: while King Alfred (r. 871-899), whom Asser wrote about, is perhaps England's most celebrated king, the bishop himself has mostly been lost to history. Aside from his Life of King Alfred (Vita Alfredi regis Angul Saxonum), which offers little information about Asser, we have only scattered references to the author himself. ${ }^{1}$ He was a Welshman and so, to some extent, a foreigner in Alfred's court. This would not have been strange, however, as Alfred's court was very cosmopolitan and included individuals from many different regions, including Mercians, Welshmen, Old

\footnotetext{
${ }^{1}$ William Henry Stevenson and Dorothy Whitelock, eds., Introduction to Asser's Life of King Alfred: Together with the Annals of Saint Neots Erroneously Ascribed to Asser (Oxford: Clarendon Press, 1959), lxv.
} 
Saxons and Franks, among others. ${ }^{2}$ From his few references to Old English in the Life, it is clear that Asser did not have a complete mastery of the language. ${ }^{3}$ It is perhaps because of the large non-English element in Alfred's court, that Alfred presents us with a model of kingship with elements not previously emphasized in Anglo-Saxon England, as Alfred would have been exposed to a diverse understanding of what that role entailed. While piety and wisdom were certainly appreciated qualities in an Anglo-Saxon king, prior to Alfred these qualities were not regarded as primary. In fact, as I demonstrated in the last chapter on Bede, too much religion could be a detrimental quality if it drew the warleader away from the neccesary business of war. In this chapter I argue that in writing the Life, Asser draws upon Einhard's Vita Karoli Magni and Sedulius Scottus's On Christian Rulers (De rectoribus Christianis) to create advice literature that promotes a conception of pastoral kingship, of a king-as-teacher of both laity and prelate, of a king who must above all be wise. At the same time, Asser is careful to show that Alfred does not abandon the traditional traits of an Anglo-Saxon king and emphasizes the idea that Alfred's piety is not in conflict with his role as warleader. The tension between war and wisdom in regards to kingship had a long history in Anglo-Saxon England, and Asser's work is critical in the history of advice literature in that he seeks to reconcile both through a rhetoric that holds these competing skills as divine gifts of kingship.

\footnotetext{
${ }^{2}$ Lapidge, "John the Old Saxon (fl. c.885-904)"; Micheal Lapidge, "John the Old Saxon (fl. c.885-904)." In Oxford Dictionary of National Biography. (Oxford University Press, 2004), http://www.oxforddnb.com/view/article/52277; Patrick Wormald, "Living with King Alfred." Haskins Society Journal: Studies in Medieval History 15 (2006): 12.

${ }^{3}$ Stevenson, Introduction to Asser's Life of King Alfred, lxxvii.
} 


\section{Purpose and Audience}

While Alfred's reign marks a critically important stage in the history of both England and the English language, there are precious little material that remains from his tenure. ${ }^{4}$ While the Anglo-Saxon Chronicle is an important source for Alfred, it is only in Asser's Life that we get a real portrait of the scholar-warrior that has been so celebrated throughout history. Only one manuscript of Asser's text was known to survive into the modern period, produced around the year 1000 at an unknown location and destroyed in the famous Ashburnham House fire in $1731 .^{5}$ The text did not seem to have circulated in its own time, and only a handful of medieval authors reference it in their work. ${ }^{6}$ Due to this lack of distribution and citation, some have questioned the text's authenticity, but these doubts are largely without evidence. ${ }^{7}$ As William Henry Stevenson correctly points out, in chapter 80 Asser lists many of the Welsh kings during this period, which have since been confirmed: "This chapter alone is a very strong argument in favour of the authenticity of the work. It is impossible that an imaginary twelfth-century English forger could have written this chapter without betraying himself into some grievous error."8 Leaving aside well-trod ground, there are other issues pertaining to the manuscript.

${ }^{4}$ Richard Philip Abels, Alfred the Great: War, Kingship, and Culture in Anglo-Saxon England (Harlow, England; New York: Longman, 1998), xv.

${ }^{5}$ Simon Keynes and Michael Lapidge, eds., Introduction to Alfred the Great: Asser's Life of King Alfred and Other Contemporary Sources (Harmondsworth, Eng; New York: Penguin Books, 1983), 57. The manuscript itself was known as Cotton Otho A.xii. Fortunately, a copy was transcribed before it was destroyed.

${ }^{6}$ Keynes and Lapidge, Introduction to Alfred the Great, 57.

${ }^{7}$ A recent notable attempt to advance the forgery argument can be found in: Smyth, Alfred P. Smyth, ed., The Medieval Life of King Alfred the Great: A Translation and Commentary on the Text Attributed to Asser (New York: Palgrave, 2002). This work was rather critically reviewed by Janet Nelson, "Waiting for Alfred." Early Medieval Europe 7 (1998): 115-24.

${ }^{8}$ Stevenson, Introduction to Asser's Life of King Alfred, lxxv. For other arguments for the text's authenticity, see: Keynes and Lapidge, Introduction to Alfred the Great, 50; Nelson, "Waiting for Alfred"; Dorothy Whitelock, The Genuine Asser. Stenton Lecture 1967. (Reading: University of Reading, 1968). 
Simon Keynes and Michael Lapidge question whether the text we now have was a finished work, or perhaps only a draft of a later version that has now been lost. One of the primary reasons for this suggestion is the twelfth-century work Annals of St. Neots, which cites Asser's Life, and "seems in some places to be more accurate than that of the Cotton manuscript, and it is possible therefore that the Bury chronicler had access to a different

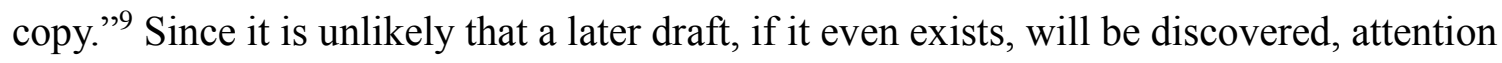
must be focused on the text that has survived and the context in which it was created.

Asser's purposes and audiences can be best understood if the Life is understood as advice literature. He uses a number of passages from the Anglo-Saxon Chronicle, but in between these, "Asser conveys the more intimate atmosphere of the court and its intellectual circle." ${ }^{10}$ Several scholars have connected Asser's work not only to Einhard, but to the larger tradition of Carolingian biography and mirrors for princes. James Campbell understands Asser's work to belong "to a lineage of Christian royal biography" beginning with Eusebius, but argues that it "has a closer affinity with the more immediate family of Carolingian and sub-Carolingian biographies of pious laymen." ${ }^{11}$ Anton Scharer argues that "The numerous elements derived from the genre of speculum principis, which seem to go far beyond those usually found in historiographical and biographical works dealing with kings, persuade me that Asser intended this work to be read as part of that genre." 12 And Alice Sheppard regards the work as "a hybrid text written in the Carolingian traditions of history and historical biography," drawing

\footnotetext{
${ }^{9}$ Keynes and Lapidge, Introduction to Alfred the Great, 57.

${ }^{10}$ Anton Scharer, "The Writing of History at King Alfred's Court." Early Medieval Europe 5, no. 2 (January 1, 1996): 186.

${ }^{11}$ James Campbell, “Asser's Life of Alfred.” In The Inheritance of Historiography, 350-900, edited by Christopher Holdsworth and T.P. Wiseman, 115-35. (Exeter, University of Exeter Press, 1986), 201-2. ${ }^{12}$ Scharer, "The Writing of History at King Alfred's Court," 204
} 
"heavily from the mirrors for princes tradition." ${ }^{13}$ Yet while these connections have been noted, not much attention has been given to how Asser might be building on and modifying that tradition. Part of the reason for this seems to be that Asser is regarded as imitating the advice literature common in Carolingian circles but otherwise alien to England. However, as I demonstrate in the previous chapter, an important part of Bede's Historia consists of laying out what Bede saw as the key principles of kingship. It is notable that Bede's Historia was translated into Old English during the reign of Alfred, and while it wasn't Alfred's own work, it was very likely a part of Alfred's "scheme of translation." ${ }^{14}$ This makes sense considering Alfred's own concern with the role of kingship, as evidenced by his participation in the translation of the Pastoral Care, to be considered more fully below. Like Bede, who was drawing on and responding to earlier advice literature such as Eusebius and Gildas, Asser is working within this larger framework. And like other writers of advice literature, Asser's text draws on history, biography, and hagiography.

A key debate among scholars concerning Asser's work is his intended audience. In her analysis of Alfredian audiences, Audrey Meaney has argued that "The Pastoral Care ... told the bishops how Alfred expected them to support him in their own sphere, as the Chronicle told the fighting man." ${ }^{\prime 15}$ Who then was expected to read Asser's Life? While a critical question, it is not one that has seen scholarly consensus. Sheppard has correctly pointed out that "Because it is written in Latin, the Vita Alfredi stands out from other Alfredian texts like the Old English Bede and Old English Orosius, histories that,

\footnotetext{
${ }^{13}$ Sheppard, "The King's Family," 411.

${ }^{14}$ Audrey Meaney, "King Alfred and His Secretariat." Parergon 11 (1975): 18.

${ }^{15}$ Meaney, "King Alfred and His Secretariat," 23.
} 
together with the Anglo-Saxon Chronicle, suggest the importance of vernacular historical writing at Alfred's court," and Sheppard surmises that unlike these other texts, it was not intended to be read at court. ${ }^{16}$ A number of scholars, including James Campbell and Simon Keynes, have argued that Asser was primarily writing for a Welsh audience in order to extend and emphasize Alfred's authority there. ${ }^{17}$ On the other hand, Janet Nelson has argued in favor of a Carolingian audience in light of the influence that Carolingian texts had on Asser. ${ }^{18}$ Anton Scharer maintains that Alfred's court was, in fact, the target audience, especially "clerical recruits" who might have been affected by stories of the king's suffering and pursuit of wisdom. ${ }^{19}$ While these various considerations have merit, and the work may in fact have had multiple audiences, I argue that Asser's primary audience was the king himself, and those kings who would follow after him.

An examination of the historical context of Asser's Life suggests that it was not suitable for external propaganda, nor was it intended for such. Around 892, after a peaceful period, Vikings once again began raiding England; it was during this same year that the Anglo-Saxon Chronicle was "published" (so to speak), "presumably because its compilers felt that their view of the past was particularly apposite at a moment of such grave national crisis, when it would have been essential to strengthen in any way possible the resolve of the English to unite under Alfred's leadership." ${ }^{20}$ It was also during this

\footnotetext{
${ }^{16}$ Sheppard, "The King's Family," 409.

${ }^{17}$ Campbell, "Asser's Life of Alfred"; Keynes, "King Alfred and the Mercians." It should be noted, however, that in Keynes and Lapidge's introduction to Alfred the Great, 42, they concede that there is "no evidence" that the Life was ever used as Welsh propaganda.

${ }^{18}$ Janet L. Nelson, "The Franks and the English in the Ninth Century Reconsidered." In The Preservation and Transmission of Anglo-Saxon Culture, edited by Paul E. Szarmach and Joel T. Rosenthal. (Kalamazoo, MI: Medieval Institute Publications, Western Michigan University, 1997), 141-58.

${ }^{19}$ Scharer, "The Writing of History at King Alfred's Court," 189.

${ }^{20}$ Keynes and Lapidge, Introduction to Alfred the Great, 42.
} 
same year that Asser wrote the Life, which was "apparently intended to serve a different, though complementary, purpose" than the Chronicle. ${ }^{21}$ If the Chronicle was produced during this time to help unite the lay Anglo-Saxons around Alfred in face of continued Viking aggression (according to Keynes and Lapidge), then it does not make sense that Asser's text would be directed towards the Welsh or Carolingians, as neither of these peoples were involved in this struggle in any meaningful way, nor was Alfred directing his attention to these areas at this time. Scharer's notion that newly arrived ecclesiastics would be interested in the text has some value, except for the fact that, again, the text did not seem to be widely read or used by ecclesiastics. ${ }^{22}$ One would still have to explain this anomaly, especially when compared to texts like the Pastoral Care, which certainly had a clerical audience, and which Alfred had copied and dedicated to various personages. If it had been Alfred's intention that Asser's Life be distributed, it seems likely that he would have done so. Instead, we have a work that was written in Latin and which apparently was not copied outside of the court. The choice of Latin might have been due to Asser's poor handle on Old English, although his Latin was not very refined either. ${ }^{23}$ The choice of Latin was also likely in imitation of Einhard, who was Asser's principal model and whose work I turn to below. Like Einhard's work, Asser's Life was intended for a more intimate audience, and it's purpose was to promote Asser's vision of kingship, a vision that saw the king as the spiritual center of the kingdom.

Asser establishes in his dedication the central sanctity of the king and positions

\footnotetext{
${ }^{21}$ Keynes and Lapidge, Introduction to Alfred the Great, 42.

${ }^{22}$ Scharer, "The Writing of History at King Alfred's Court," 189.

${ }^{23}$ Keynes and Lapidge, Introduction to Alfred the Great, 54; Stevenson, Introduction to Asser's Life of King Alfred, lxxvii.
} 
himself, a bishop, well below Alfred:

To my esteemed and most holy lord, Alfred, ruler of all the Christians of the Island of Britain, king of the Angles and Saxons, Asser, lowest of all the servants of God, wishes thousandfold prosperity in this life and in the next, according to the desires of his prayers. ${ }^{24}$

In order to put this dedication in context, it is useful to compare it to Bede. While Bede's preface in which he describes the work is rather long, his actual dedication is shorter than Asser's: "To the most glorious King Ceolwulf, Bede, servant of Christ and priest." 25 Calling one's king esteemed [venerabili] or most glorious [gloriosissimo] can be considered perfunctory language when dealing with a monarch, as well as the signing of one's own name. Bede offers little else. Asser, however, calls Alfred "piissimo" [most holy]; it is the only time that Asser uses the word in its superlative form, and he uses the positive form [pius] only twice in the Life, both to describe Alfred. ${ }^{26}$ Asser establishes from the beginning that Alfred possesses a high level of sanctity, while locating himself as the "lowest of all the servants of God" [omnium servorum Dei ultimus]. It must be remembered that Asser enjoyed a very close working relationship with Alfred. Asser frequently assisted Alfred in his studies and had a hand in the translations of both the Pastoral Care and Consolation of Philosophy. ${ }^{27}$ So Asser's dedication should not be read

\footnotetext{
${ }^{24}$ Keynes and Lapidge, Alfred the Great, Preface, p. 67; Stevenson, Asser's Life of King Alfred, Preface, p. 1: "Domino meo venerabili piissimoque omnium Brittanniae insulae Christianorum rectori, Ælfred, Anglorum Saxonum regi, Asser, omnium servorum Dei ultimus, millemodam ad vota desideriorum utriusque vitae prosperitatem." Latin text from

25 "Gloriosissimo regi Ceoluulfo Beda famulus Christi et presbyter." Bede. Bede's Ecclesiastical History of the English People, Preface.

${ }^{26}$ Stevenson, Asser's Life of King Alfred, ch. 74, p. 56; ch. 99, p. 86.

${ }^{27}$ Keynes and Lapidge, Alfred the Great., ch. 88, p. 99; Stevenson, Introduction to Asser's Life of King Alfred, lxviii-lxix.
} 
as coming from a distant subject hopeful of gaining favor through flattery. Asser already held a highly honored position at court. Alfred had pleaded with him to remain with him rather than return to Wales, granted him several dioceses, and bequeathed a large sum to him in his will. ${ }^{28}$ Rather than flattery, Asser is creating an exalted vision of Alfred, just as Eusebius created for Constantine. It is not a biography meant to awe foreign courts, but rather an exemplum for Alfred himself, and for those who would follow after him.

\section{Wisdom and Education}

Asser's Life was influenced by the emerging Carolingian tradition of mirrors-forprinces, especially Einhard's Vita Karoli Magni. Asser wrote his Life during Alfred's life and did not continue the account up to the point of Alfred's death. He begins by drawing upon annals before moving into more personal information. These qualities of the text have sometimes been cause for criticism, but Asser was not the first to write in such a way. ${ }^{29}$ The life of Ludwig the Pious by Tegan was written during Ludwig's life in 836 and not continued to the point of his death and begins by retelling annalistic material, and another Vita of Ludwig written by an author known only as "the Astronomer"; it is likely that Asser was familiar with these works, and he certainly knew of Einhard's Vita, as part of chapter 73 was adapted from Einhard's preface, and there are some striking similarities in structure and theme overall. ${ }^{30}$ Like Asser, Einhard was a contemporary and close companion to the monarch he wrote about who depended upon his own experiences in his

\footnotetext{
${ }^{28}$ Stevenson, Introduction to Asser's Life of King Alfred, lxv-lxviii.

${ }^{29}$ Stevenson, Introduction to Asser's Life of King Alfred, lxxx.

${ }^{30}$ Stevenson, Introduction to Asser's Life of King Alfred, lxxxi.
} 
writing. ${ }^{31}$ Asser's work, like the Vita Karoli Magni and other Carolingian works of advice literature, "turn[s] inward to focus on morality, virtue, and the private realm, consistently positioning the king as an example of the faith life of his subjects." ${ }^{32}$ In doing so, "Asser shifts the reader's focus from the king's defense of his kingdom to the political and cultural life of the court and the personal life of the king." ${ }^{\prime 33}$ Both Asser and Einhard begin their texts by reproducing from the annals the results of wars that neither writer ever saw or participated in before moving to the personal life of the king. In both cases, this personal life tends to center around matters of education and piety, creating an image of kingship centered in wisdom and holiness.

Einhard portrays Charlemagne as a king very concerned with personal wisdom and with the education of his children. It is related that Charlemagne:

spoke Latin as well as his own language, but Greek he understood better than he could speak it ... He was zealous in his cultivation of the liberal arts, and respected and honored highly those who taught them ... the king spent a great deal of time and effort studying rhetoric, logic, and especially astronomy. He learned how to calculate and with great diligence and curiosity investigated the course of the stars. He also tried his hand at writing and to this end always kept writing tablets and notebooks under his pillow in bed in order to practice during spare moments. ${ }^{34}$

${ }^{31}$ Firchow and Zeydel, Introduction to Vita Karoli Magni, 13.

${ }^{32}$ Sheppard, "The King's Family," 411.

${ }^{33}$ Sheppard, "The King's Family," 410.

${ }^{34}$ Einhard, Vita Karoli Magni: The Life of Charlemagne. Edited by Evelyn Scherabon Firchow and Edwin H. Zeydel. (Coral Gables, Fla: University of Miami Press, 1972), ch. 25, p. 92-3: "In quibus Latinam ita didicit, ut aeque illa ac patria lingua orare sit solitus, Grecam vero melius intellegere quam pronuntiare poterat ... Artes liberales studiosissime coluit, earumque doctores plurimum veneratus magnis adficiebat honoribus . . . apud quem et rethoricae et dialecticae, praecipue tamen astronomiae 
If we take Einhard at his word, Charlemagne was a very well-educated man for the ninth century, especially for a layman. It is notable that Charlemagne wrote with his own hand and sought to improve upon this skill, as some have questioned whether Alfred actually wrote the material attributed to him or whether he would have only dictated it. ${ }^{35}$ Unlike most ecclesiastics, Charlemagne did not begin his education until adulthood, and so his studies did not come easily for him. He sought to remedy this in his own children, whom he gave a broad education. Einhard relates that "his sons as well as his daughters were to be instructed first in those liberal arts in which he took most interest himself. As soon as the boys were old enough they had to learn how to ride, hunt, and handle weapons in Frankish style. ${ }^{" 36}$ Charlemagne is concerned that his daughters as well as his sons were given a broad education, with more specialized training to be divided between the sexes. While Charlemagne wanted his sons to be wise, he did not neglect the more traditional martial skills of the nobility, as even hunting was a form of war training. In Einhard's view, a future ruler needed a balance of both wisdom and war.

Asser also drew on Sedulius Scottus in his conception of kingship, especially in the importance of wisdom for a king. Sedulius was an Irishman who took up residence in Frankia in the mid-ninth century. ${ }^{37}$ Sedulius was a contemporary of Asser and wrote his On Christian Rulers, his advice manual for Lothar II (835-869), the king of Lotharingia, between 855 and 859, that is, around the same time that Alfred was memorizing English

ediscendae plurimum et temporis et laboris inpertivit. Discebat artem conputandi et intentione sagaci siderum cursum curiosissime rimabatur. Temptabat et scribere tabulasque et codicellos ad hoc in lecto sub cervicalibus circumferre solebat, ut, cum vacuum tempus esset."

${ }^{35}$ Malcolm R. Godden, “Did King Alfred Write Anything?" Medium Aevum 76, no. 1 (June 2007): 1.

${ }^{36}$ Einhard, Vita Karoli Magni, ch. 19, p. 79: "ut tam filii quam filiae primo liberalibus studiis, quibus et ipse operam dabat, erudirentur. Tum filios, cum primum aetas patiebatur, more Francorum equitare, armis ac venatibus exerceri fecit."

${ }^{37}$ O'Donovan and O'Donovan, From Irenaeus to Grotius, 221. 
poetry from his mother's book. ${ }^{38}$ Sedulius, in his work, was concerned that kings listen to the advice of wise council and not rely only on his own judgment. ${ }^{39}$ The work itself is rather Boethian in style and prosimetric, as it follows each section of prose with a section of verse. Concerning a king's need for wisdom, Sedulius wrote:

All royal power, which has been divinely established for the benefit of the state, should be embellished not so much with vain powers and earthly might as with wisdom and the veneration of God. For, if the eminence of the king is adorned by religion and wisdom, then, without a doubt, the people will be governed by the art of prudent counsel, enemies will be cast down by a merciful Lord and both the provinces and the kingdom will be preserved ... Wisdom exalted Solomon above all the kings of the earth, for he cherished it from his youth and became a lover of its beauty. ${ }^{40}$

The Solomonic comparison here was common for Carolingian rulers and allows Sedulius to establish that wisdom, rather than "earthly might," is the source of lasting royal power. It is wisdom that allows a king to overcome his enemies rather than his martial skills. This is a very radical notion, and one can imagine that it was not always an easy proposition for Germanic kings to accept. Both Asser and Alfred mitigate this rather complete reliance on wisdom by taking a more balanced approach. Consider Alfred's words on this subject from his Preface to the Pastoral Care:

It has very often come into my mind, what wise men there formerly were throughout England, both of sacred and secular orders; and how blessed

\footnotetext{
${ }^{38}$ O'Donovan and O'Donovan, From Irenaeus to Grotius, 221.

${ }^{39}$ O'Donovan and O'Donovan, From Irenaeus to Grotius, 223-4, § 2, 6.

${ }^{40}$ O'Donovan and O'Donovan, From Irenaeus to Grotius, 223, § 4.
} 
times there were then throughout England; and how the kings who had authority over the people in those days obeyed God and his messengers ... and how they prospered both with war and with wisdom . . ${ }^{41}$

Here Alfred's concept of kingship is strikingly close to Sedulius's in that, ultimately, he understands wisdom to be the most critical quality of a king. For Alfred and Asser, it is not enough for a king to be a warleader, but at the same time they do not propose a king lacking in martial ability. While Asser is influenced by Sedulius's idea of the wise king, he also mitigates this image to fit the circumstances Alfred was facing, and in many places promotes the vision of a physically imposing Alfred.

Asser is also careful in describing the nature of Alfred's wisdom and its source. He does not give much credit to Alfred's parents for his wisdom. In fact, he is quite critical of them in terms of the education they gave to Alfred. Alfred is shown to be a great lover of wisdom from a very early age, indeed, even from birth:

From the cradle onwards, in spite of all the demands of the present life, it has been the desire for wisdom, more than anything else, together with the nobility of his birth, which have characterized the nature of his noble mind; but alas, by the shameful negligence of his parents and tutors he remained ignorant of letters until his twelfth year, or even longer. ${ }^{42}$

${ }^{41}$ Henry Sweet, ed., King Alfred's West-Saxon Version of Gregory's Pastoral Care (Millwood, N.Y.: Kraus Reprint, 1988), 4-8. [my translation; the text is that of the Cotton MS]: "com suiðe oft on gemynd, hwelce wutan gio wæron geond Angelkynn, ægðer ge godcundra hada ge woruldcundra; \& hu gesæliglica tida pa wæron geond Angelcynn; \& hu pa kyningas pe ðone anwald hæfdon ðæs folces Gode \& his ærendwrecum hirsumedon . . \& \& hu him ða speow ægðer ge mid wige ge mid wisdome..."

${ }^{42}$ Keynes and Lapidge, Alfred the Great, ch. 22, p. 74-75; Stevenson, Asser's Life of King Alfred, ch. 22, p. 19-20: "Cui ab incunabulis ante omnia et cum omnibus praesentis vitae studiis, sapientiae desiderium 
This passage not only shows Alfred to prize wisdom above all things, but criticizes those who raised him for not valuing education highly enough. Asser's exclamation, "proh dolor!" emphasizes that he, and presumably Alfred himself, considers this to be a terrible neglect and a poor upbringing. His parents' behavior here is described as indigna, which can mean "shameful" or even "cruel." It is a very strong condemnation and odd because in other places Asser gives praise to Alfred's parents. One explanation is that it gives Asser a reason for why Alfred still had to learn some things as an adult despite his precocious wisdom.

While Alfred's parents are shown to have cared for Alfred, his wisdom and nobility are shown to be in-born rather than learned. His father Æthelwulf is said to have "loved [Alfred] more than his other sons," and showed him special favor by taking him to Rome to be anointed by the Pope and then taking him with him on a second journey to Rome. ${ }^{43}$ While it is unclear exactly how one should interpret this anointing, it seems difficult to charge Æthelwulf with neglect. His mother Osburh seems even less open to criticism on this point. Asser describes her as "a most religious woman, noble in character and noble by birth. ${ }^{\circ 4}$ She could apparently read English and is also described as encouraging literacy in her children:

One day, therefore, when his mother was showing him and his brothers a book of English poetry which she held in her hand, she said: 'I shall give

cum nobilitate generis, nobilis mentis ingenium supplevit; sed, proh dolor! indigna suorum parentum et nutritorum incuria usque ad duodecimum aetatis annum, aut eo amplius, illiteratus permansit."

${ }^{43}$ Keynes and Lapidge, Alfred the Great, ch. 8-11, p. 69-70; Stevenson, Asser's Life of King Alfred, ch. 11, p. 4: "Eodemque anno cum magno honore Romam perrexit praefatumque filiumsuum Ælfredum iterum in eandem viam secum ducens, eo quod illum plus ceteris filiis diligebat."

${ }^{44}$ Keynes and Lapidge, Alfred the Great, ch. 2, p. 68; Stevenson, Asser's Life of King Alfred, ch. 2, p. 4: "Mater quoque eiusdem Osburh nominabatur, religiosa nimium femina, nobilis ingenio, nobilis et genere." 
this book to whichever one of you can learn it the fastest.' Spurred on by these words, or rather by divine inspiration, and attracted by the beauty of the initial letter in the book, Alfred spoke as follows in reply to his mother, forestalling his brothers (ahead in years, though not in ability): 'Will you really give this book to the one of us who can understand it the soonest and recite it to you?' Whereupon, smiling with pleasure she reassured him, saying: 'Yes, I will.' He immediately took the book from her hand, went to his teacher and learnt it. When it was learnt, he took it back to his mother and recited it. ${ }^{45}$

Following this episode, Alfred is said to have continued on in his education, learning psalms as well as prayers. Clearly, this moment was the catalyst for his pursuit of wisdom. This event would have taken place before 856 , before the death of his mother, so Alfred would have been seven years old at most. ${ }^{46}$ Despite this being a critical moment, and Osburh's clear role in Alfred's love of books, Asser seems at great pains not to credit her for this. After Osburh gives her challenge, Asser writes the line, "Spurred on by these words, or rather by divine inspiration ..." [Quo voce, immo divina inspiratione ... . ]. Here immo serves as a corrective. Essentially Asser is saying, "In case there was any confusion, it was divine inspiration and definitely not his mother who inspired his

\footnotetext{
${ }^{45}$ Keynes and Lapidge, Alfred the Great, ch. 23, p. 75; Stevenson, Asser's Life of King Alfred, ch. 23, p. 20: "Cum ergo quodam die mater sua sibi et fratribus suis quendam Saxonicum poematicae artis librum, quem in manu habebat, ostenderet, ait: 'Quisquis vestrum discere citius istum codicem possit, dabo illi illum.' Qua voce, immo divina inspiratione, instinctus Ælfredus, et pulchritudine principalis litterae illius libri illectus, ita matri respondens, et fratres suos aetate, quamvis non gratia, seniores anticipans, inquit: 'Verene dabis istum librum uni ex nobis, scilicet illi, qui citissime intelligere et recitare eum ante te possit?' Ad haec illa, arridens et gaudens atque affirmans: 'Dabo,' infit, 'illi.' Tunc ille statim tollens librum de manu sua, magistrum adiit et legit. Quo lecto, matri retulit et recitavit."

${ }^{46}$ Keynes and Lapidge, Alfred the Great, p. 239, n.48.
} 
wisdom." As Catherine Karkov succinctly states in her analysis of the passage, "Mothers, indeed women in general, do not figure in this vision of nation building." ${ }^{, 47}$ While not disagreeing with Karkov's assessment, I would argue that earthly fathers do not figure very much either. Asser presents us with an Alfred that received his wisdom directly from God, through divine grace, in a manner similar to many saints' accounts. In a later passage, Asser affirms that he considered this the proper scriptural view: "As Solomon says: 'The heart of the king' (that is, his wisdom) 'is in the hand of the Lord."'48 There is also very much a connection here between Alfred and Solomon in this divine gift of wisdom. Of course this creates a potential conflict for Asser: if Alfred is wise by grace alone, then does it matter what educational program his parents followed? This then creates further questions, such as whether this grace was to extend to Alfred's own children? Perhaps Alfred was to be considered an exception here, because the king himself certainly sought to serve as the teacher of others, including his children.

Alfred, just like Charlemagne, had both his sons and daughters educated in the liberal arts. Alfred himself outlined his ideas of education in his preface to Gregory the Great's Pastoral Care, a work that he translated with the assistance of Asser. He declared: that all the youth in England of free men, who are rich enough to be able to devote themselves to it, be set to learn as long as they are not fit for any other occupation, until they are well able to read English writing: and let those be afterwards taught more in the Latin language who are to continue

\footnotetext{
${ }^{47}$ Catherine E. Karkov, “The Mother's Tongue and the Father's Prose." Parallax 18, no. 3 (2012): 29.

${ }^{48}$ Keynes and Lapidge, Alfred the Great, ch. 99, p. 106; Stevenson Asser's Life of King Alfred, ch. 99, p. 86: "ut dixit Salomon, 'Cor regis in manu Domini,' id est consilium." Asser is quoting here from Proverbs 21:1. While Asser used the Vetus Latina for his Bible quotations, in this case the verse is identical to the Vulgate. For Asser's use of scripture, see: Bryan Carella, "Asser's Bible and the Prologue to the Laws of Alfred." Anglia 130, no. 2 (2012): 195-206.
} 
learning and be promoted to a higher rank. ${ }^{49}$

While an educated nobility would figure prominently in his goals, he extended his education to the sons of all "free men" [friora monna] who could be spared for education. It likely would have only been rather wealthy parents who could spare the labor of their children, so the school was still very much restricted to the elite. Still, in this passage one can read Alfred's genuine desire to spread education as widely as possible. Asser tells us that this "Alfredian School" included:

all the nobly born children of virtually the entire area, and a good many of lesser birth as well. In this school books in both languages - that is to say, in Latin and English—were carefully read; they also devoted themselves to writing, to such an extent that, even before they had the requisite strength for manly skills (hunting, that is, and other skills appropriate to noblemen), they were seen to be devoted and intelligent students of the liberal arts. ${ }^{50}$

Asser seems to closely follow Einhard's structure in his description of an educational program. Both describe a liberal arts training for children, but end by describing the "manly skills." Both authors seem to put in contrast the liberales artes, and the more

${ }^{49}$ Sweet, King Alfred's West-Saxon Version of Gregory's Pastoral Care, 6-7 [Sweet's Translation; Cotton Mss.]: "ðætte eal sio gioguð pe nu is on Angel kynne friora monna, para pe pa speda hæbben pæt hie ðæm befeolan mægen, sien to leornunga oðfæste, pa hwile pe hi to nanre oðerre note ne mægen, oð ðone first pe hie wel cunnen Englisc gewrit arædan: lære mon siððan furður on Lædengeðeode pa pe mon furðor læran wille \& to hierran hade don wille."

${ }^{50}$ Keynes and Lapidge, Alfred the Great, ch. 75, p. 90; Stevenson, Asser's Life of King Alfred, ch. 75, p. 58: "cum omnibus pene totius regionis nobilibus infantibus et etiam multis ignobilibus, sub diligenti magistrorum cura traditus est. In qua schola utriusque linguae libri, Latinae scilicet et Saxonicae, assidue legebantur, scriptioni quoque vacabant,ita, ut antequam aptas humanis artibus vires haberent, venatoriae scilicet et ceteris artibus, quae nobilibus conveniunt, in liberalibus artibus studiosi et ingeniosi viderentur." 
vigorous humanae artes, which pertained to the traditional war-play of noblemen. Einhard includes riding, hunting, and the use of weapons among the humanae artes; Asser mentions only hunting while noting there were other skills as well. ${ }^{51}$ Asser here and elsewhere is concerned to portray Alfred and his sons as masculine and warlike, and generally will follow a description of scholarly activity by emphasizing those masculine physical activities that were expected of kings. These depictions of masculinity are important and show a certain continuity with Bede's conceptions of kingship. Before examining them more fully, however, let us consider how Asser positions Alfred in terms of piety and in relation to other ecclesiastics. Just as in the case of education, Asser here seems to be drawing on Einhard for inspiration.

\section{Sacred Kingship: pro vice Dei}

As discussed in Chapter 1, I take Eusebius as the starting point of Christian advice literature, as he was the first to create a theological framework for Christian kingship. An important aspect of the Eusebian vision was the central importance of the monarch in the salvation process. The monarch held an ill-defined sacred office, positioned above both laymen and clergy, as a reflection of the heavenly king. This concept was present from very early on in Anglo-Saxon formulations as well. For example, King Ine of Wessex (d. 725) was described as king mid Godes gife and Rex dei gratia [king by the grace of God]; this became "a standard formulation of the notion that kings reigned by divine ordination," and to this day remains inscribed on British coins. ${ }^{52}$ During Charlemagne's

${ }^{51}$ Einhard, Vita Karoli Magni, ch. 19, p. 79.

${ }^{52}$ Oakley, Kingship, 98. 
reign (from 768 to 814), this formulation of sacred kingship was stated in even stronger terms:

It was universally professed by Charlemagne's subjects, clerical and lay, that strict obedience was owed to the commands of their monarch, who ruled not only 'by God's grace' (gratia Dei), as had Byzantine emperors, Merovingian kings, and Frankish bishops, but 'in God's place' (pro vice $D e i$ ), provided that his commands did not flagrantly violate divine law and justice. Rebellion or conspiracy against 'the Lord's anointed,' entrusted with the protection of the Lord's people, was an affront to God himself that merited the anathema of the church. ${ }^{53}$

Charlemagne used this position to vigorously advance the cause of Christianity on the Continent and took an active role in the management of the church.

Einhard portrays Charlemagne as being very pious and as correcting the clergy in matters of faith. He "attended church regularly in the morning and evening and took part in the late-night hours and morning mass. He was especially concerned that everything done in the church should be carried out with the greatest possible dignity." ${ }^{" 54}$ It seems that Charlemagne frequently needed to correct the behavior of priests: "Often he admonished the sacristans to see to it that nothing unseemly or unclean was brought into the church or left there." ${ }^{55}$ Charlemagne saw it as his duty to "admonish" [commonens] the clergy, indicating that others were not fulfilling this function. Charlemagne does not

${ }^{53}$ O'Donovan and O'Donovan, From Irenaeus to Grotius, 174.

${ }^{54}$ Einhard, Vita Karoli Magni, ch. 26, p. 94-95: "Ecclesiam et mane et vespere, item nocturnis horris et sacrificii tempore, quoad eum valitudo permiserat, inpigre frequentabat, curabatque magnopere, ut omnia quae in ea gerebantur cum qua maxima fierent honestate."

${ }^{55}$ Einhard, Vita Karoli Magni, ch. 26, p. 95: "aedituos creberrime commonens, ne quid indecens aut sordidum aut inferri aut in ea remanere permitterent." 
delegate this task to bishops, but rather sees to it himself that the Church fulfills its obligations. This clearly indicates that Charlemagne was not (and did not see himself) in the position of a layman, but rather as one elevated above the hierarchy and therefore able to correct them. In addition to his reforms at home, Einhard relates that Charlemagne gave alms to Christians in many distant lands, including Egypt, Syria, Africa, Jerusalem, Alexandria, and Carthage. ${ }^{56}$ These alms to distant Christians shows Charlemagne's imperialistic mindset, in that he regarded himself as responsible on some level for Christians residing even outside of his realm, and thus saw himself as an Emperor of Christendom. The king's piety and central role in the faith of his subjects are themes that Asser also focuses on in his Life.

While Charlemagne is portrayed as a diligent practitioner of religious obligations, Asser takes matters one step further by presenting Alfred in terms that would generally be reserved for saints. He describes Alfred as being:

transfixed by the nails of many tribulations, even though he is invested with royal authority: from his twentieth year until his forty-fifth (which is now in course) he has been plagued continually with savage attacks of some unknown disease, such that he does not have even a single hour of peace in which he does not either suffer from the disease itself, or else, gloomily dreading it, is not driven almost to despair. ${ }^{57}$

I am in basic agreement with Sheppard, who argues that "Asser uses the conventional

${ }^{56}$ Einhard, Vita Karoli Magni, ch. 27, p. 97.

${ }^{57}$ Keynes and Lapidge, Alfred the Great, ch. 91, p. 101; Stevenson, Asser's Life of King Alfred, ch. 91, p. 76: "Erat itaque rex ille multis tribulationum clavis confossus, quamvis in regia potestate constitutus; nam a vigesimo aetatis anno usque ad quadragesimum quintum annum, quem nunc agit, gravissima incogniti doloris infestatione incessanter fatigatur, ita ut ne unius quidem horae securitatem habeat, qua aut illam infirmitatem no sustineat aut sub illius formidine lugubriter prope constitutus non desperet." 
Carolingian hagiographical topos of the suffering body"; she overstates the case, however, in declaring that "His Alfred has the weak and suffering corporeality of a saint ... [B]y diminishing the power of the physical, Asser refocuses his readers on the relational and communal significance of the saint-like king's body." ${ }^{58}$ As I demonstrated above (and more fully below), Asser is careful to emphasize Alfred's physical capabilities. Alfred is saint-like, but not after the fashion of a passive martyr.

Just as Asser immediately follows the descriptions of learning with humanae artes, so he follows the potentially weakening passage of Alfred's suffering with a rapidfire list of his capabilities in war and nation management:

What shall I say of his frequent expeditions and battles against the Vikings and of the unceasing responsibilities of government? What of his daily involvement with the nations which lie from the Mediterranean to the farthest limit of Ireland?--for I have even seen and read letters sent to him with gifts from Jerusalem by the patriarch Elias. And what of the cities and towns to be rebuilt and of others to be constructed where previously there were none? $?^{59}$

Despite his affliction, Alfred leads men into battle contra paganos and is presented as a figure involved in Christendom the world over. Asser gives us an image of Alfred as a warrior saint engaged in a holy defensive war against invading unbelievers. As Kent Hare has correctly noted, Bede's earlier "enthusiasm" for martial kings like Oswald over those

${ }^{58}$ Sheppard, "The King's Family," 411.

${ }^{59}$ Keynes and Lapidge, Alfred the Great, ch. 91, p. 101; Stevenson, Asser's Life of King Alfred, ch. 91, p. 76: "Quid loquar de frequentibus contra paganos expeditionibus et bellis et incessabilibus regni gubernaculius? De cotidiana nationum, quae in Tyrreno mari usque ultimum Hiberniae finem habitant? Nam etiam de Hierosolyma ab Elia patriarcha epistolas et dona illi directas vidimus et legimus. De civitatibus et urbibus renovandis et aliis, ubi nunquam ante fuerant, construendis?" 
who retreated from active life "would prove important in legitimizing martial activities by holy kings," including Alfred's "religious warfare" against the Vikings during his reign. ${ }^{60}$ Hare argues that when the Anglo-Saxons converted to Christianity, there arose a tension in kings between the desire to live an ascetic life and the royal duty of a king to lead his men into battle. ${ }^{61}$ Bede noted both responses, but preferred that a king fulfill his duties rather than consider monastic life. ${ }^{62}$ Bede "recognized that the king's role as warchief was necessary, but it was a necessary evil"; later writers would not "take such pains to dissociate those same kings' holiness from their martial activities. ${ }^{93}$ While Einhard praises Charlemagne for his generalship in his war against the Saxons, and notes that the Saxons were natura feroces [savage by nature] and belonged to cultui daemonum [a cult of demons], he does not attach any great religious significance to Charlemagne's conquest of the area. ${ }^{64}$ Rather the conflict is presented as the king quashing the annoying border raids that had been ongoing. The Saxons are not so much a feared foreign invader as they are uncivilized barbarians who need to be put into their place. The language is that of imperial Rome. So although Einhard seeks to portray Charlemagne as a just and pious ruler who oversees Church affairs, he does not position the emperor as a divine agent in the same way that Asser portrays Alfred. At not time does Einhard push Charlemagne's piety to the point of sainthood, as Asser continually does. Asser continually pushes Alfred one step further than Charlemagne.

As Charlemagne is described in correcting the Church, Alfred corrects all the men

\footnotetext{
${ }^{60}$ Hare, "Heroes, Saints, and Martyrs," n.p.

${ }^{61}$ Hare, "Heroes, Saints, and Martyrs," n.p.

${ }^{62}$ Hare, "Heroes, Saints, and Martyrs," n.p.

${ }^{63}$ Hare, "Heroes, Saints, and Martyrs," n.p.

${ }^{64}$ Einhard, Vita Karoli Magni, ch. 7, p. 46-7.
} 
in his realm like a father does his children. All ranks of society, both sacred and lay, are shown to depend upon Alfred's divinely given wisdom:

Yet once he had taken over the helm of his kingdom, he alone, sustained by divine assistance, struggled like an excellent pilot to guide his ship ... For by gently instructing, cajoling, urging, commanding, and (in the end, when his patience was exhausted) by sharply chastising those who were disobedient and by despising popular stupidity and stubbornness in every way, he carefully and cleverly exploited and converted his bishops and ealdormen and nobles, and his thegns most dear to him, and reeves as well. $^{65}$

Alfred alone, guided by divine inspiration, can guide and direct the kingdom in both spiritual and physical affairs. Asser does not privilege the spiritual over the physical here, but rather presents the king as a master of both realms. The king held a unique position in that he was the only lord who received anointing (a sacrament otherwise reserved for the church hierarchy); thus, the king led both praying and fighting men, and he himself guided them in both prayers and battle. ${ }^{66}$ Nicole Discenza has argued that Alfred inserted himself "into the church hierarchy between pope and bishop," but this is a somewhat anachronistic view of the situation.$^{67}$ Pope Gregory VII's reformist policies in the

${ }^{65}$ Keynes and Lapidge, Alfred the Great, ch. 91, p. 101-02; Stevenson, Asser's Life of King Alfred, ch. 91, p. 76: "Sed tamen ille solus divino fultus adminiculo susceptum semel regni subernculum, veluti gubernator praecipuus, navem suam ... Nam assidue suos episcopos et comites ac nobilissimos, sibique dilectissimos suos ministros, necnon et praepositos, quibus post Dominum et regem omnis totius regni potestas, sicut dignum, subdita videtur, leniter docendo, adulando, hortando, imperando, ad ultimum inoboedientes, post longam patientiam, acrius castigando, vulgarem stultitiam et pertinaciam omni modo abominando, ad suam voluntatem et ad communem totius regniultilitatem spientissime usurpabat et annectebat."

${ }^{66}$ Loyn, The Governance of Anglo-Saxon England, 85.

${ }^{67}$ Nicole Guenther Discenza, "Alfred's Verse Preface to the Pastoral Care and the Chain of Authority." 
eleventh century, which would instigate the Investiture Controversy, was still nearly two hundred years distant during the time of Alfred. The lines of spiritual hierarchy in AngloSaxon England, especially during the reign of Alfred, were very much like those among the Carolingians:

Although inspired by papal anointings and crownings of Frankish royalty, the Carolingian prelates did not view their authority in these proceedings as depending on the pope's. The church in which they and their kings were to minister as Christ's viceregents was less the universal Roman imperial church than the West-Frankish populus Dei. Nevertheless, they were ever mindful that the orthodox faith the emperor was elevated to protect was preeminently that of the Church of Rome. ${ }^{68}$

So too did Alfred's Anglo-Saxon bishops, notwithstanding that many of them had been drawn from abroad, see themselves as servants of the Anglo-Saxon people, who were embodied in the person of the king. The Church's support for Alfred "was direct and unqualified. Bishops attended Alfred's councils, and even fought actively in the royal host. ${ }^{" 69}$ Sedulius also understood a king's position to be a sacred one, stating that "the divine order has appointed" a king as:

God's vicar in the government of his church and ... granted authority over both orders (of prelates and subjects) that he decide what is just for every person; that under his direction the first order (of prelates) should preside over teaching and ministering properly; and that the order of subjects be

Neophilologus 85, no. 4 (October 2001): 627.

${ }^{68}$ O'Donovan and O'Donovan, From Irenaeus to Grotius, 175.

${ }^{69}$ Loyn, The Governance of Anglo-Saxon England, 72. 
faithfully and devoutly obedient. ${ }^{70}$

He also understood it to be a king's responsibility to "wisely plan to convene synodal assemblies two or three times every year," and for the king to "examine" the deeds of the priesthood to ensure they were being diligent. ${ }^{71}$ It was this way during the reign of Alfred, as by this time the synod had been absorbed into the witan. ${ }^{72}$

It is anachronistic to even think about a modern concept like the separation of church and state during Alfred's time. The Church provided the king with literate men who assisted in giving advice in the witan, in writing records, in judgments, in receiving oaths, in both writing and enforcing law (escaped prisoners were excommunicated). ${ }^{73}$ In return the king kept peace in the land, upheld ecclesiastical law, gave "royal sanction" to holy days. Sedulius saw the king's protection as a religious duty:

A just prince is then known to honor the Most High when he shows himself the helper and protector of those who labor in the Lord's field, as it were, the stewards of the Great King. For, it is certain that the Almighty in his kindness will graciously dispose the affairs of an earthly prince to the degree He sees that prince solicitious with regard to His affairs, namely, those of Holy Church. ${ }^{74}$

The king and the church were two branches of Anglo-Saxon government, with the king clearly in the position of authority. So while Alfred's management of the church was more hands-on than had been seen in the past, his behavior was not regarded as impinging

\footnotetext{
${ }^{70}$ O'Donovan and O'Donovan, From Irenaeus to Grotius, 227, sect 19.

${ }^{71}$ O'Donovan and O'Donovan, From Irenaeus to Grotius, 225, sect 11.

72 Cubitt, "Councils, Church," 126.

${ }^{73}$ Loyn, The Governance of Anglo-Saxon England, 72.

${ }^{74}$ O'Donovan and O'Donovan, From Irenaeus to Grotius, 225, sect 11.
} 
upon the roles of ecclesiastics. Throughout most of the medieval period it is the ecclesiastics themselves who vigorously argue that the king is part of the spiritual hierarchy.

\section{Solomonic exemplum}

Both Alfred and Charlemagne are portrayed with Solomonic imagery in relation to administration, law, international focus, and wisdom. As noted in previous chapters, King David was the exemplum most used by earlier writers, most notably by Gildas and Bede. Gildas used David to demonstrate how the sin or piety of a king affected the wellbeing of his entire people. ${ }^{75}$ For Bede, David represented the struggle of tribal warfare often experienced by Anglo-Saxon kings of the eighth century, as well as the need for kings to be guided by priests. Davidic kingship imagery can still be found in the ninth and tenth centuries in both England and on the Continent, but around the time of Charlemagne, Solomon became an increasingly important exemplum. Sedulius uses both David and Solomon as exempla. ${ }^{76}$ So while Alfred found parallels between himself and David in his translation of the Psalter, Asser instead compares him to Solomon. Part of this may be explained by developments in both kingship and society in England. England looked quite a bit different in the tenth century than it did in the eighth, and so the nature of kingship evolved in that time span as well. ${ }^{77}$ Solomon was much more of a reigning

${ }^{75}$ Gildas, The Ruin of Britain, 39.3.

${ }^{76}$ O'Donovan and O'Donovan, From Irenaeus to Grotius, 222, sect 1. Aside from his frequent references to David and Solomon, Sedulius also frequently references Constantine. These three seem to represent the highest paragons of kingship for Sedulius, which aligns with my arguments in chapter 1.

${ }^{77}$ In the eighth century England was divided into several competing Anglo-Saxon kingdoms, and raiding formed a crucial part of kingly economics. Alfred's reign marks the beginning of a period of unification in which power became centralized in the king. During this unification period trade became the most important aspect of the economy, and raiding and tribute no longer were crucial to successful kingship. 
king than David in terms of building programs, administration, justice, and so on. From this standpoint, David was almost barely a king. He is most frequently portrayed in the field as a semi-nomadic warlord, at least in the parts of scripture that Bede most draws upon. Bede values a king who is faithful to God, but, most of all, one who is a warleader. While Alfred certainly is remembered as a remarkable general, this was not an aspect that Asser focuses on. Aside from his administration, Solomon is also shown as presiding over law and justice in his kingdom. In addition, Solomon is said to have received numerous foreign visitors and to be known throughout the ancient world. He solidified these international relations through his 700 wives, many of whom were foreign. Above all, Solomon was known for his wisdom, which he received directly from God, and which Asser also links to Alfred: "he resembled the holy, highly esteemed and exceedingly wealthy Solomon, king of the Hebrews, who, once upon a time, having come to despise all renown and wealth of this world, sought wisdom from God, and thereby achieved both.. ${ }^{, 78}$ Both Solomon and Alfred used wisdom in judgments, administration, and in the writing of books. Interestingly, both Solomon and Alfred were also younger sons who were anointed at a young age. ${ }^{79}$ After Charlemagne, the associations with Solomon grew stronger among the Carolingians, with Charles the Bald (823-877) having "himself presented as a second Solomon ... the Solomonic imagery was evoked not only in a mirror for princes, but also in panegyrical poetry, the illumination of Biblical

These developments are examined in Chapter 4 in more detail.

${ }^{78}$ Keynes and Lapidge, Alfred the Great, ch. 76, p. 92; Stevenson, Asser's Life of King Alfred, ch. 76, p. 60: "in hoc prium et opinatissimum atque opulentissimum Salomonem Hebraeorum regem aequiparans, qui primitus, despecta omni praesenti gloria et divitiis, sapientiam a Deo deposcit, et etiam utramque invenit."

${ }^{79}$ Scharer, "The Writing of History at King Alfred's Court,"191. 
manuscripts and on the cathedra sancti Petri. ${ }^{" 80}$ In description and imagery, it became increasingly important that a king possess the gift of divine wisdom, just as Solomon did. It bears repeating, however, that this increasing emphasis on wisdom was not at the expense of the more traditional qualities of kingship, chief of which is the king's ability to lead his warriors in battle.

\section{Humanae Artes}

As mentioned earlier, anytime Asser describes Alfred in a way that might indicate the king was too monkish or lacking in masculine vigor, he immediately follows the passage with a description of Alfred's physical prowess, and emphasized the role of the humanae artes. This pattern is too predictable to be a coincidence and is most likely a conscious choice on the part of Asser, who would have been familiar with Bede's critical attitude towards kings who did not fulfill their duties as warleader. Activities such as hunting were not merely "manly" hobbies for a king, they were a form of martial training. Boar hunting was serious business, and Asser relates how Carloman, king of the western Franks, was torn to pieces by a boar while hunting. ${ }^{81}$ Medieval boar hunting "required great skill with a weapon" to be successful; hunting manuals compare the boar "to a fierce warrior... reflecting an earlier and more heroic age" since "the boar was considered the most dangerous animal to hunt." ${ }^{" 82}$ One could not be an infirm and monkish king and go boar hunting. Following the previously quoted passage describing

\footnotetext{
${ }^{80}$ Scharer, "The Writing of History at King Alfred's Court,"191.

${ }^{81}$ Keynes and Lapidge, Alfred the Great, ch. 68, p. 87.

${ }^{82}$ Richard Almond, Medieval Hunting (Stroud: Sutton, 2003), 66.
} 
Alfred's youth and his "desire for wisdom, more than anything else," ${ }^{83}$ Asser immediately describes Alfred's hunting skills with great seriousness: “An enthusiastic huntsman, he strives continually in every branch of hunting, and not in vain; for no one else could approach him in skill and success in that activity, just as in all other gifts of God, as I have so often seen for myself." ${ }^{" 84}$ Asser wants to emphasize to the reader that Alfred is a master hunter in all of its forms. He even considers Alfred's hunting ability a divine gift, using the same language as that used in describing Alfred's divine wisdom, which he was also granted from God. Just as Bede emphasized the importance of the martial aspects of kingship to the scholarly Ceolwulf, so Asser is here reminding Alfred and future kings to keep a balance between wisdom and war.

Asser uses the same formulation in chapter 74, of emphasizing the need for both war and wisdom within the same passage. Chapter 74 is notable in that it shows Alfred at his weakest moment, or at least that is how some scholars have read it, and found it unpalatable. Asser describes how Alfred is struck by a physical malady during his wedding and collapses in pain. Following this, he explains how Alfred had previously prayed that his physical disease might not take the form of "leprosy or blindness, or some other such disease, which so quickly render men useless and contemptible by their onslaught." $" 85$ It is perhaps not surprising that this stop at a church to pray occurred during a hunting trip in Cornwall. As before, Asser follows suggestions of weakness by

${ }^{83}$ Keynes and Lapidge, Alfred the Great, ch. 22, p. 74-75.

${ }^{84}$ Keynes and Lapidge, Alfred the Great, ch. 22, p. 75; Stevenson, Asser's Life of King Alfred, ch. 22, p. 20: "In omni venatoria arte industrius venator incessabiliter laborat non in vanum; nam incomparabilis omnibus Dei donis, fuit, sicut et nos saepissime vidimus."

${ }^{85}$ Keynes and Lapidge, Alfred the Great, ch. 74, p. 88-89; Stevenson, Asser's Life of King Alfred, ch. 74, p. 55: "Timebat enim lepram aut caccitatem, vel aliquem talem dolorem, qui homines tam cito et inutiles et despectos suo adventu efficiunt." 
descriptions of humanae artes. But even Alfred's prayer reflects his concern with physical prowess. Alfred does not pray to be relieved of suffering, since he accepts such suffering like a saint, but instead asks that he not be rendered useless [inutiles] for kingship. This passage, and indeed the entirety of chapter 74 , has not sat well with a number of scholars. Charles Plummer argued that it was an interpolation, since it detracted from the heroic quality of Alfred, and regarded it as a symptom of Asser's "Celtic Character," and "morbid religiosity." 86 The dislike for this passage ran so strong that several scholars, including Dorothy Whitelock, cut it out of their editions completely. ${ }^{87}$ The issue these scholars had is expressed by Smyth's view that the Alfred presented by Asser "is in conflict with much of what we know about Alfred from contemporary sources." Smyth cannot reconcile the Chronicle's version of Alfred as a "macho warrior" with Asser's "pious wimp," who "could never have ... won the support of his battle-hardened warriors." In Smyth's view, a man who collapsed at his own wedding did not possess the physical prowess required to be king. ${ }^{88}$ While in general Smyth's understanding of AngloSaxon kingship is correct, insofar as ealdormen and thegns looked to the king to be a capable warleader, he misreads the narrative Asser is constructing and underestimates the power attached to sacred kingship. Alfred was not physically weak, as evidenced by his numerous battles and his mastery of hunting. Had Alfred been unable to lead his troops or hunt, this would have indeed been problematic, which is exactly why Asser emphasizes that Alfred does, indeed, possess these qualities. Aside from this, it must be remembered

\footnotetext{
${ }^{86}$ Campbell, "Asser's Life of Alfred," 203. Alfred Smyth also greatly disliked the passage, but then, he considered the entire work to be a forgery.

${ }^{87}$ Nelson, "Waiting for Alfred," 123.

${ }^{88}$ Smyth, The Medieval Life of King Alfred, 203-4.
} 
that Alfred's affliction was divinely given, as yet another mark of the divine favor, that same divine favor that granted Alfred his wisdom and his hunting skills.

One of the clearest episodes in which Asser shows the balance between pious wisdom and martial duty is in chapter 38. This is before Alfred was king, when he was accompanying his brother, King Æthelred, in a campaign against the Vikings. The battle was imminent and Alfred was upon the field, but Æthelred was still at his prayers. Forced to make a decision, Alfred acted with decisive vigor:

[Alfred] finally deployed the Christian forces against the hostile armies, as he had previously intended (even though the king had not yet come), and acting courageously, like a wild boar, supported by divine counsel and strengthened by divine help, when he had closed up the shield-wall in proper order, he moved his army without delay against the enemy. ${ }^{89}$

This moment, perhaps more than any other, gives us the paragon of kingship that Asser wants to convey in a single image. Like in many other cases, Alfred is shown as superior to his brothers. Here Æthelred is depicted as overly monkish at the expense of martial duty. Asser's brilliant image manages to show us an Alfred who fights like a "wild boar" while simultaneously operating under "divine counsel." It is the perfect symmetry of the physical and spiritual, and the imagery captures the idea of the holy warrior that Alfred has been known for ever since.

\footnotetext{
${ }^{89}$ Keynes and Lapidge, Alfred the Great, ch. 38, p. 79; Stevenson, Asser's Life of King Alfred, ch. 38, p. 29: "demum viriliter aprino more Christianas copias contra hostiles exercitus, ut ante proposuerat, tamen quamvis rex adhuc non venerat, dirigens, divino fretus consilio et adiutorio fultus, testudine ordinabiliter condensata, confestim contra hostes vexilla movet."
} 


\section{Conclusion}

Asser did not seek to diminish "the power of the physical" in his portrait of Alfred, despite the arguments of a number of scholars to the contrary. ${ }^{90}$ Through his descriptions of wars and especially through his portrait of Alfred the hunter, Asser continually reminds the reader of the king's capabilities in humanae artes. That his Life demonstrates another aspect of Alfred not seen in the Chronicle should not be surprising or be understood as conflicting. I see the Chronicle as having been largely written as a unifier of Alfred's laymen; it was a form of propaganda, to put it more bluntly. Asser's Life may indeed have been less appealing to Alfred's battle-hardened thegns, but that is irrelevant, as they were never intended to read it. There is an urge, since the work is written in Latin, to assume it was intended for Anglo-Saxon (or Welsh, or Carolingian) clerics. It is unlikely that Asser had a local clerical audience in mind. As Alfred himself wrote, a great number of Anglo-Saxon bishops could not even translate a letter from Latin into English. ${ }^{91}$ It was for this very reason that the Pastoral Care and other works were translated from Latin in the first place, so that ecclesiastics could read works for their benefit. As I argued earlier, the primary audience for Asser's Life was the king himself, and also future kings.

As with Einhard and Charlemagne, Asser genuinely seems to have been devoted to Alfred. And so part of his motivation was likely the desire to honor and uplift his king. But at the same time, we can detect a close cultural relationship between ninth-century England and the Carolingians. ${ }^{92}$ Asser's idea of kingship was influenced by Carolingian

\footnotetext{
90 Sheppard, "The King's Family," 411; Smyth, The Medieval Life of King Alfred, 203-4.

${ }^{91}$ Sweet, King Alfred's West-Saxon Version of Gregory's Pastoral Care, 3.

92 Helen M. Cam, Local Government in Francia and England: A Comparison of the Local Administration
} 
writers like Einhard and Sedulius, but Asser did not simply imitate his sources. Asser was a more creative and intelligent writer than he often gets credit for. While Carolingians advanced the concept of the Solomonic wise king, this concept was not completely integrated with the humanae artes. The ideas are mentioned separately, or in parallel. Or in the case of Sedulius, success in war was entirely dependent upon a king's dedication to wisdom. Asser developed a more unified vision of kingship with his portrait of Alfred, of a ruler who could fight like a boar, be divinely inspired, and have a great love of learning. This image of Alfred would be one that carried through the ages.

and Jurisdiction of the Carolingian Empire with That of the West Saxon Kingdom (London: Hodder \& Stoughton, 1912), 6-17. 


\section{CHAPTER 4}

\section{WULFSTAN}

The history of England during the years 991-1016 was filled with instability and conflict, in contrast to the relative peace and prosperity during the reign of Edgar the Peaceful (r. 959-975) and the early reign of Æthelred II (r. 978-1016). ${ }^{1}$ The fact that Æthelred came to the throne after his older brother, Edward the Martyr (r. 975-78), was murdered would cast a dark shadow over the entirety of Æthelred's reign. This was compounded by seemingly endless Scandinavian invasions, which eventually culminated in Cnut's conquest of England in 1016.. In the midst of this turbulent period, Wulfstan "Lupus," Archbishop of York (d. 1023) was an indefatigable advisor and political actor. ${ }^{2}$ Dorothy Bethurum compares his political role as archbishop to that of a prime minister, and while anachronistic, this analogy is apt. ${ }^{3}$ Wulfstan served under and advised three separate kings, and guided them all with a singular vision he had for kingship and England. These kings were said to have loved Wulfstan like a brother and honored him like a father. ${ }^{4}$ While Wulfstan's works have been analyzed for their structural and rhetorical features, ${ }^{5}$ Jonathan Wilcox's statement that "more can yet be uncovered about

\footnotetext{
${ }^{1}$ Æthelred II lost control of his kingdom during 1013-1014 to Swein Forkbeard.

${ }^{2}$ Not to be confused with Wulfstan I, Archbishop of York (d. 956) or Wulfstan, Bishop of Worcester (d. 1095). Wulfstan was one of the most prolific writers of the Anglo-Saxon period. Some of these works were in Latin, but the majority were written in Old English. He wrote a number of homilies on various subjects, was instrumental in several law codes, wrote The Institutes of Polity (a political-philosophical work on the organization of society, and is credited with two poems from the Anglo-Saxon Chronicles, celebrating the succession of King Edgar and King Edward.

${ }^{3}$ Dorothy Bethurum, ed., The Homilies of Wulfstan (Oxford: Clarendon Press, 1957$), 87$.

${ }^{4}$ E. O. Blake, Liber Eliensis (London: Office of the Royal Historical Society, 1962), ii.87, pp. 155-57.

${ }^{5}$ Roger Fowler, "Some Stylistic Features of the Sermo Lupi." Journal of English and Germanic Philology
} 
the political context" of Wulfstan's works remains true. ${ }^{6}$ In this chapter I will focus my attention on two works by Wulfstan that are of particular interest for the subject of kingship and advice literature: the Sermo Lupi ad Anglos and the Institutes of Polity. In many ways these two documents represent a culmination of Anglo-Saxon advice literature. Wulfstan draws on much of the kingship theory that I have examined in earlier chapters and develops these ideas further. Like Gildas, he links the failings of the nation to the sins of the people; like Bede, he advocates for an aggressive policy of military expansion; like Asser and Sedulius, he promotes the idea of wisdom as a king's principal virtue. One major change in how Wulfstan envisions kingship is that he largely abandons the idea of king as a ruler over a people (gens) and instead holds him responsible for Christendom. Unlike Bede, who closely linked kingship and ethnicity, Wulfstan uses religious affiliation as the in-group, and directs the king to eradicate heathenism. In promoting a concept of a united Christian leadership, Wulfstan moves sharply away from older Germanic conceptions of loyalty, and moves towards a conception of Christians united in aggressive holy war against unbelievers, an idea that would become fully realized less than a century later in the First Crusade. ${ }^{7}$

65 (1966): 1-18; Stephanie Hollis, "The Thematic Structure of the Sermo Lupi." Anglo-Saxon England 6 (1977): 175-95; Raachel Jurovics, "Sermo Lupi and the Moral Purpose of Rhetoric." In The Old English Homily and Its Backgrounds, edited by Paul E Szarmach and Bernard F. Huppé, 203-20. Albany: University of New York, 1978.

${ }^{6}$ Wilcox, "Wulfstan's Sermo Lupi Ad Anglos as Political Performance," 376.

${ }^{7}$ Carl Erdmann, The Origin of the Idea of Crusade. Translated by Marshall Withed Baldwin and Walter A Goffart. (Ann Arbor: University of Michigan, University Library, 2010), 57ff; Jonathan Riley-Smith, The First Crusade and the Idea of Crusading (London: Continuum International Publishing Group, 2012), 1. While it lies outside the bounds of this project, Pope Urban II's call for the First Crusade in 1095 could be considered very similar to the advice literature I have considered in this project, only on a much larger scale. The emergence of the Crusades had much to do with the Gregorian Reforms of the eleventh century, which, similarly to Wulfstan's ideas, sought to unite Christendom. But while these strains of thought are connected, it should be noted that there are still important differences between holy war and a Crusade. For instance, a Crusade also contained an important element of pilgrimage. For an examination of holy war during the Anglo-Saxon period, see: Hare, "Christian Heroism and 


\section{Wulfstan's History and Relationship to Kings}

In order to better understand the political situation that Wulfstan was addressing, I will briefly survey Wulfstan's career and the historical events between 1002-1016. Unlike figures such as Bede or Asser, we have a relative wealth of information about Wulfstan and the period during which he lived. He is thought to have come from a good family, although nothing is known about his father, and his mother died in childbirth via Caesarean section. ${ }^{8}$ He was from the Fenlands in the East Midlands, an area known as the "Holy Land of the English," as it held many notable monasteries, such as Ramsey, Thorney, Peterborough, Ely, and Crowland. ${ }^{9}$ He was a Benedictine monk, and his reforming activities align with other ecclesiastics who were part of the Benedictine Reform. ${ }^{10}$ In 996 he became Bishop of London, and his name appears as a witness in many charters during this period. ${ }^{11}$ In 1002 he was made Archbishop of York and also given Worcester in plurality. ${ }^{12}$ Despite being the Archbishop of York, Wulfstan would remain in the more prosperous south through the reign of Æthelred, whom he served as "advisor and lawmaker."13 Even at this point there was a cultural divide between northern

Holy War in Anglo-Saxon England."

${ }^{8}$ Bethurum, The Homilies of Wulfstan, 55.

${ }^{9}$ Milton McC Gatch, Preaching and Theology in Anglo-Saxon England: Alfric and Wulfstan (Toronto: University of Toronto Press, 1977), 18; John Wise and W. Mackreth Noble. Ramsey Abbey: Its Rise and Fall (Huntingdon: Ellis \& Cooper, 1882), front matter, n.p.; Patrick Wormald, "Archbishop Wulfstan: Eleventh-Century State Builder." In Archbishop of York: The Proceedings of the Second Alcuin Conference, edited by Matthew Townend, 10-27. Studies in the Early Middle Ages 10. (Turnhout: Brepols, 2004), 12.

${ }^{10}$ Bethurum, The Homilies of Wulfstan, 57; Gatch, Preaching and Theology in Anglo-Saxon England, 18.

${ }^{11}$ Bethurum, The Homilies of Wulfstan, 58-9.

${ }^{12}$ Bethurum, The Homilies of Wulfstan, 59. While holding multiple sees was formally forbidden, these two sees had been held together since 972 by Wulfstan's predecessors, and so it had become accepted practice in this case. Bethurum notes that "Of the two sees Worcester was much the more wealthy and important, for York was by that time a Danish city and its library and cathedral possessions, presumably destroyed in the ninth-century Danish raids, had never been replaced, nor had it recovered the lands lost from its ancient estates."

${ }^{13}$ Bethurum, The Homilies of Wulfstan, 59. 
and southern England. The north remained more culturally linked to Scandinavia, a result of ninth-century Danish settlements and the establishment of the Danelaw in 886 in the treaty between Alfred and Guthrum.

\begin{tabular}{|l|l|}
\hline \multicolumn{2}{|l|}{ Table 2: Reigns of Kings around Wulfstan's Time ${ }^{14}$} \\
\hline Edgar the Peaceful & $959-975$ \\
\hline Edward the Martyr & $975-978$ \\
\hline Æthelred the Unready & $978-1013$ \\
\hline Swein Forkbeard & $1013-1014$ \\
\hline Fthelred the Unready (restored) & $1014-1016$ \\
\hline Edmund Ironside & 1016 \\
\hline Cnut & $1016-1035$ \\
\hline
\end{tabular}

Through the reigns of Edgar, Edward and Æthelred (see Table 2), England dramatically increased its wealth, which attracted Scandinavian adventurers. Most of this new money was generated due to peace, which enabled lower taxation and military expenditure, and an increase in trade between England and Northern Europe. ${ }^{15}$ This wealth continued to increase, despite the succession issues that followed the murder of Edward the Martyr. ${ }^{16}$ Swein Forkbeard, king of Denmark (r. 986-1014), led his first raiding expedition to England in 991. It did not involve a large force bent on conquest;

\footnotetext{
${ }^{14}$ Wulfstan was most active during the years 1006-23.

${ }^{15}$ Howard, Swein Forkbeard's Invasions, 14.

${ }^{16}$ Howard, Swein Forkbeard's Invasions, 16.
} 
rather it was a raiding expedition for loot, as was common amongst Scandinavian

adventurers. ${ }^{17}$ Further raids were to follow, and Æthelred responded to these aggressions

by offering tribute for peace. ${ }^{18}$ While Æthelred has often been criticized for these

payments, it must be remembered that he did so on the advice of his witan. ${ }^{19}$

Despite any agreements, Ethelred did not trust the Scandinavians. ${ }^{20}$ In response,

on St. Brice's Day, 13 November 1002 an order was sent out to slay the Scandinavian

mercenaries. ${ }^{21}$ Once the massacre started, it was not restricted to mercenaries. Merchants,

women, and children of Scandinavian origin were also killed, and it is possible that King

Swein's sister and brother-in-law were murdered during the purge. ${ }^{22}$ Considering that

there was already a strong motivation for the Scandinavians to go to England for loot,

${ }^{17}$ Howard, Swein Forkbeard's Invasions, 33. Swein may in fact have been present at the Battle of Maldon. As Howard notes, it is very difficult to determine Swein's precise status at this time, as the historical evidence conflicts. Some sources present him as the leader of a unified Scandinavia, while others state that he was an exile from his own country. Neither situation conflicts with his leading a band of adventurers abroad. He may have done so because he was supremely secure in his homeland or because he was in desperate straits.

${ }^{18}$ Howard, Swein Forkbeard's Invasions, 41-46. Æthelred paid the Scandinavians $£ 10,000$ in tribute for a temporary truce, but it is important to note that the Scandinavians never actually left England. In 993, the raids continued, and Swein led attacks on London, and throughout Essex, Kent, Sussex, and Hampshire; Æthelred's response was to again pay tribute, this time in the amount of $£ 16,000$.

${ }^{19}$ Howard, Swein Forkbeard's Invasions, 46-61. As noted in Levi Roach. Ethelred the Unready (New Haven; London: Yale University Press, 2016), 313, Alfred also paid tribute to Scandinavian raiders in order to buy a truce, and Roach argues that the two figures responded rather similarly, while also acknowledging that Alfred was a superior general. However, as Howard makes clear, Æthelred's payments did nothing to lessen the attacks, and in fact probably encouraged them. This led to Æthelred's 993 decision to hire the Scandinavians as mercenaries to fight against future invasions, paying $£ 22,000$ to Olaf Tryggvason, who had raided London with Swein, to switch his loyalties to England. But in 1001 another Scandinavian army invaded, causing great damage and loss of life, so that in 1002 the English once again offered tribute for a truce, this time for $£ 24,000$.

${ }^{20}$ Howard, Swein Forkbeard's Invasions, 61. Some of those who were supposed to be in his personal employ had joined the Scandinavian raiders. In addition to this, the king received various rumors of plots to overthrow him.

${ }^{21}$ Howard, Swein Forkbeard's Invasions, 61.

${ }^{22}$ Howard, Swein Forkbeard's Invasions, 61. In Germanic custom, if a person's kin was slain, they had a duty to seek revenge. While the massacre probably only amounted to a few hundred individuals, the rights of wergild and revenge held for a very extended family. This would have amounted to a few thousand aggrieved Scandinavians who would seek revenge. 
Æthelred's actions catalyzed Swein Forkbeard's invasions of 1006 and $1013 .{ }^{23}$ By this time, Æthelred's handling of the situation had made him unpopular, and the untamed area of Northumbria sympathized with their Scandinavian kin. ${ }^{24}$ In fact, N.J. Higham argues that the Northumbrians invited Swein to invade..$^{25}$ In any case, Swein seems to have won a diplomatic victory, as "nearly half the country had agreed to accept Swein as king soon after he appeared with his army." ${ }^{26}$ Swein campaigned south and by January 1014 all of England was firmly under his control and Æthelred was forced to flee to Normandy. ${ }^{27}$

While the country was being torn apart by conflict, Wulfstan was busy writing. He began working on his Institutes of Polity 1006x1010, likely after Thorkell led his invasion of England but before Swein's more successful invasion of $1013 .{ }^{28}$ However, Wulfstan would continually revise the Institutes until his death in 1023, leaving us with several versions. ${ }^{29}$ The Sermo Lupi ad Anglos was written in 1014 and revised several times thereafter. ${ }^{30}$ Scholars disagree on the exact dates for Wulfstan's works, and the issue is made more complex by the fact that Wulfstan often revised and left multiple versions. ${ }^{31}$ In addition, Wulfstan often reused material in his writings. Patrick Wormald has argued

${ }^{23}$ Howard, Swein Forkbeard's Invasions, 76, 103. As Howard shows, this invasion was different in nature from the earlier attacks. Rather than consisting of a ragtag collection of various raiding parties united only for ad hoc purposes, the invasion of 1006 represented a united Scandinavian "national" force, and its purpose was both revenge and conquest. The army was led by a man named Thorkell; for whatever reason, Swein had decided to remain at home. Æthelred paid Thorkell £36,000 for a truce. The end effect was that Swein created another army and invaded himself in 1013.

${ }^{24}$ N. J. Higham, The Death of Anglo-Saxon England. (Stroud: Sutton Publications, 2000), 56-9.

${ }^{25}$ Higham, Death of Anglo-Saxon England, 56-9.

${ }^{26}$ Howard, Swein Forkbeard's Invasions, 109.

${ }^{27}$ Howard, Swein Forkbeard's Invasions, 122-23.

${ }^{28}$ Wormald, "Archbishop Wulfstan," 26-27.

${ }^{29}$ Andrew Rabin, ed., The Political Writings of Archbishop Wulfstan of York. Manchester Medieval Sources Series. (Manchester: Manchester University Press, 2015), 101.

${ }^{30}$ Wilcox, "Wulfstan's Sermo Lupi ad Anglos as Political Performance," 375, 391. There are three primary editions of Wulfstan's Sermo Lupi: BH, C, and EI.

${ }^{31}$ Andy Orchard, "Crying Wolf: Oral Style and the Sermones Lupi." Anglo-Saxon England 21 (1992): 239. 
for a set of date ranges based upon the idea that Wulfstan would have expanded rather than contracted these borrowings over time. ${ }^{32}$ I generally use Wormald's dates as a basis, but also consider historical context. For dating the Sermo Lupi I rely on Wilcox, who uses political context for evidence and convincingly argues that Wulfstan's 1014 version [BH] was the original, and that he made the Sermo Lupi shorter in revisions [EI and C]. ${ }^{33}$ Wilcox's dating here is not mere pedantic interest, as it is critical in understanding the context in which Wulfstan was writing. The political situation between 1014-1016 was especially volatile, and Wulfstan was constantly adapting and revising in response to the changing political landscape. What makes the BH version of the Sermo Lupi significant is that it mentions Æthelred by name; this reference was removed in later versions. ${ }^{34}$

Wilcox's arguments for the dating of $\mathrm{BH}$ it helps us to better understand the political contexts in which the Sermo Lupi was written. On 16 February 1014 the witan was called together, probably by Wulfstan, to crown Swein as king, who died thirteen days before the meeting took place. ${ }^{35}$ As Wilcox points out, due to travel times, the meeting would have been arranged much before that. ${ }^{36}$ The $A-S$ Chronicles tell us:

Đa geræddan pa witan ealle, ge hadode ge læwede, pet man æfter pam cyninge Æðelrede sende, $\square$ cwædon pet him nan leofre hlaford nære

\footnotetext{
${ }^{32}$ Wormald, "Archbishop Wulfstan," 13.

${ }^{33}$ Wilcox, "Wulfstan's Sermo Lupi ad Anglos as Political Performance," 391. For arguments that Wulfstan originally wrote the Sermo Lupi in 1012 and that the 1014 version was the revision, see: Malcolm Godden, “Apocalypse and Invasion in Late Anglo-Saxon England." In From Anglo-Saxon to Early Middle English: Studies Presented to E.G. Stanley, edited by Malcolm Godden, Douglas Gray, and Terry Hood, 130-62. (Oxford: Clarendon, 2001), 143-52; and Dorothy Whitelock, Sermo Lupi Ad Anglos (Exeter: University of Exeter, 1980), 1-5.

${ }^{34}$ Bethurum, The Homilies of Wulfstan, BH 70-71, C 82-83, EI 77-78, pp. 257-58, 263, 270. See: Wilcox, "Wulfstan's Sermo Lupi ad Anglos as Political Performance," 384.

${ }^{35}$ Wilcox, "Wulfstan's Sermo Lupi ad Anglos as Political Performance," 376.

${ }^{36}$ Wilcox, "Wulfstan's Sermo Lupi ad Anglos as Political Performance," 381.
} 
ponne heora gecynde hlaford gif he hi rihtlicor healdan wolde ponne he ær dyde." ${ }^{37}$

[Then advised all the witan, both ecclesiastical and lay, that they send for King Æthelred, and they said that no lord was dearer to them than their native lord, if he would rule them more justly than he did before]. This witan which gathered to crown Swein arrived with their object dead. It was a momentous meeting. They could have chosen to proclaim Cnut, who stood in the north with an army. This choice was not unthinkable, as Wulfstan and others seem to have been rather critical of Æthelred's reign. Instead, the witan invited their gecynde hlaford to return if he would rule rihtlicor. Wilcox sees Wulfstan's hand in this language because of the characteristic rihtlicor..$^{38}$ In addition, by inviting Æthelred to return, Wulfstan and the rest of the witan were in a position to negotiate the terms, an advantage they did not have with Cnut. As Frank Stenton has remarked, these negotiations for Æthelred's return “are of great constitutional interest as the first recorded pact between an English king and his subjects. ${ }^{39}$ These were the highly unusual circumstances of the Sermo Lupi's composition, a period in which Wulfstan and other members of the witan held considerable power. If one were to merely look at this moment in time, one could perhaps understand those nineteenth-century historians who saw the witan as a proto-parliament. It also helps us to understand some of Wulfstan's boldness in both his writing and deeds, as Æthelred allowed his witan a great deal of authority.

\footnotetext{
${ }^{37}$ Susan Irvine, ed., The Anglo-Saxon Chronicle: A Collaborative Edition. Vol. 7 MS. E. (Cambridge: D.S. Brewer, 2004), [1014], p. 71.

${ }^{38}$ Wilcox, "Wulfstan's Sermo Lupi ad Anglos as Political Performance," 380.

${ }^{39}$ Stenton, Anglo-Saxon England, 386.
} 
Despite Wulfstan's negotiations with Æthelred in 1014, he seems to have not entirely approved of Æthelred's reign. When Æthelred fled, many of his close advisors went with him; Wulfstan did not. Records show him in York consecrating a new Bishop of London to replace the one that fled with Æthelred. ${ }^{40}$ Swein was a popular ruler, especially in the north, and during this period Wulfstan seems to have accepted the change. But after Swein's death and Æthelred's return to England, Cnut retreated back to Denmark. By this time Æthelred was old and he himself died in 1016. This left three contenders for the throne: Cnut; Æthelred's eldest son Edmund Ironside; and Edward, Æthelred's eldest son with his last wife, Queen Emma. Cnut returned to England and quickly claimed the north, where Scandinavian loyalty remained; Edmund Ironside tried to rally support in Wessex, while Emma controlled London. As noted below, Wulfstan engaged in a propaganda campaign for Edmund from Worcester, but it was a lost cause. Edmund never had wide support, nor did most of the kingdom acknowledge him as king.41 Edmund conveniently died in 1016; sources vary on the cause of his death but Henry of Huntingdon claims he was murdered by stabbing while on the privy. ${ }^{42}$ Edmund's younger brother Eadwig was also murdered that same year. ${ }^{43}$ Emma then agreed to marry Cnut, creating an alliance between them, which served to quash any further claimants to the throne.

Above all, Wulfstan was what would now be called a politician; his focus and energy were directed to matters of state, and he always positioned himself to be in a place

\footnotetext{
${ }^{40}$ Howard, Swein Forkbeard's Invasions, 106.

${ }^{41}$ Howard, Swein Forkbeard's Invasions, 6.

${ }^{42}$ Henry of Huntingdon, The History of the English People 1000-1154. Translated by Diana Greenway. Reissue edition. (Oxford: Oxford University Press, 2009), 15.

${ }^{43}$ Pauline Stafford, Queen Emma and Queen Edith: Queenship and Women's Power in Eleventh-Century England (Oxford: Blackwell Publishers, 2004), 225-26.
} 
of maximum influence. After Edmund Ironside died, Wulfstan resigned the see of Worcester and relocated to York to serve Cnut as advisor. ${ }^{44}$ "That meant that he left the very stronghold of learning and monasticism, Worcester, to work in a Danish city among a population imperfectly Christianized, in a region where the Benedictine reformation had never been very effective." ${ }^{45}$ Cnut was very receptive to Wulfstan's goals, and "put himself under Wulfstan's tutelage. ${ }^{\$ 46} \mathrm{Had}$ Wulfstan been primarily interested in more monastic pursuits, he would have remained in Worcester. Worcester was also a rich diocese, while York was poor. As noted earlier, this poverty was likely the reason Worcester had been attached to York in the first place. ${ }^{47}$ But York was where the new king was, it was the new center of political power, and Wulfstan liked to be in places of power. As Andrew Rabin has argued, "Wulfstan used his episcopate to advance his vision of a 'Holy Society', one in which the organization of a Christian state mirrored both the divinely ordained hierarchy of a Christian cosmos and the moral order of the individual Christian soul. ${ }^{, 48}$ Above all, he saw himself as a political advisor. That is not to say he wasn't dedicated to the Church or Benedictine reforms, but he was more interested in exerting reform through secular powers rather than living as a reclusive monk like his friend Ælfric. ${ }^{49}$ Furthermore, while many of the writings we have from Wulfstan are

\footnotetext{
${ }^{44}$ However, as Gatch points out, it is entirely possible that he merely appointed a suffragan bishop to Worcester and maintained control over the diocese (Gatch, Preaching and Theology in Anglo-Saxon England, 18). Wormald also argues that Wulfstan likely controlled Worcester in some way (Wormald, "Archbishop Wulfstan," 12).

${ }^{45}$ Bethurum, The Homilies of Wulfstan, 63.

${ }^{46}$ Bethurum, The Homilies of Wulfstan, 64.

${ }^{47}$ Bethurum, The Homilies of Wulfstan, 59.

${ }^{48}$ Rabin, The Political Writings of Archbishop Wulfstan, 2.

${ }^{49}$ Gatch, Preaching and Theology in Anglo-Saxon England, 19. As Gatch notes, Wulfstan worked closely with Ælfric in many instances, and often looked to him in theological matters. Also see: Malcolm Godden, "The Relations of Wulfstan and Elfric: A Reassessment." In Archbishop of York: The Proceedings of the Second Alcuin Conference, edited by Matthew Townend, 353-74. Studies in the Early Middle Ages 10. (Turnhout: Brepols, 2004), 362ff; Joyce Hill, “Authorial Adaptation: Ælfric,
} 
homilies, these were primarily written to be preached to the witan during assemblies rather than to a generic audience attending church services. ${ }^{50}$ It is telling that despite his liturgical duties as an Archbishop that “very few of Wulfstan's extant homiles stem from specifically liturgical occasions. ${ }^{" 51}$ His message was guided by contemporary politics rather than the Church calendar. Between 850-1066 church synods were absorbed into the witan and did not meet separately, so the witan represented the united authority of both secular and ecclesiastical authority. ${ }^{52}$ So Wulfstan's typical audience would have been a mixed group of the most powerful individuals in England: the king, æðelingas, ealdormen, thanes, bishops, and abbots. It is important to remember this, because while it may seem that a homily like the Sermo Lupi ad Anglos was meant for the entire populace of England, it would have been heard and read by the elite members of the witan listed above.$^{53}$ In modern terms, then, Wulfstan's homilies were more like speeches given before parliament than Sunday sermons. While they certainly contained religious themes, Wulfstan abandoned theological subtlety, exempla, allegories, or historical allusions in favor of a more straightforward legal style ${ }^{54} \mathrm{He}$ combined religious and political themes into a united vision directed towards those most able to effect change within society.

Wulfstan and the Pastoral Letters." In Text and Language in Medieval English Prose: A Festschrift for Tadao Kubouchi, edited by Akio Oizumi, Jacek Fisiak, and John Scahill, 63-75. Studies in English Medieval Language and Literature 12. (Frankfurt am Main: Peter Lang, 2005), 63.

${ }^{50}$ Gatch, Preaching and Theology in Anglo-Saxon England, 19.

${ }^{51}$ Joyce Tally Lionarons, The Homiletic Writings of Archbishop Wulfstan: A Critical Study. Anglo-Saxon Texts 14. (Woodbridge: D.S. Brewer, 2010), 109.

${ }^{52}$ Cubitt, "Councils, Church," 125-26; Maddicott, The Origins of the English Parliament, 6.

${ }^{53}$ Lower members of society would likely heard of these matters second hand, as the members of the witan returned to their respective home locations, they could have shared the information, either through copies of the homily or by word of mouth.

${ }^{54}$ Gatch, Preaching and Theology in Anglo-Saxon England, 20-22. As Gatch notes, in this regard he was the complete opposite of Ælfric, who employed an exegetical approach more common to monastics. Lionarons, The Homiletic Writings, 54 agrees with this assessment, but does point out a rare exception of allegory in Wulfstan's Secundum Lucam. 


\section{An Era of Propaganda}

Compared to many periods of Anglo-Saxon history about which we know very little, the early eleventh century is one rich in documentation. However, this material must all be handled warily as most of it was written with a political motive in mind. As discussed in Chapter 3, Alfred used vernacular writing and texts as a means of promoting not only his kingship, but also his vision of kingship. During Wulfstan's time, texts were widely recognized as political tools, and they were used by the English, Scandinavians, and later by the Normans. As Ian Howard notes, Wulfstan "believed very strongly in the value of maintaining a written record of the laws, homilies and annals which were probably used at important assemblies."55 When Æthelred died in April 1016, Wulfstan sought to rally support for Edmund Ironside by "updating" the Anglo-Saxon

Chronciles.56 This version of the A-S Chronicles, best illustrated by the Worcester Chronicle, had annals "covering the reigns of King Æthelred and King Edmund.” written "by one man" up to 1016.57 During this time Wulfstan was in Worcester, where it was likely composed, and the scribes there would have been under his supervision. In 1016, Wulfstan left Worcester to reside in York and serve Cnut.58 These new annals focus on the activities of Edmund Ironside, presenting him as a heroic king in marked contrast to Æthelred.59 This demonstrates that Wulfstan understood clearly the power of writing, especially vernacular writing, to shape public opinion and perception. It also serves as a reminder that materials written by politically-minded ecclesiastics must be handled

\footnotetext{
${ }^{55}$ Howard, Swein Forkbeard's Invasions, 3.

${ }^{56}$ Howard, Swein Forkbeard's Invasions, 3.

${ }^{57}$ Howard, Swein Forkbeard's Invasions, 3. The Worcester material was also included in C, E, F ms.

${ }^{58}$ Bethurum, The Homilies of Wulfstan, 63.

${ }^{59}$ Howard, Swein Forkbeard's Invasions, 4-5.
} 
carefully and with a healthy amount of skepticism, as the story the annals present can be far from reality:

In practice, Edmund was never recognized as king by the whole of England and his six-month reign was no more than a postscript to the exceptionally long reign of his father. However, so much favourable propaganda was written about him in these sources that Edmund Ironside has been long-remembered as one of the great hero kings of Anglo-Saxon times, whilst his father has been denigrated as one of the most ineffective kings ever to have ruled England.60

To some extent, the propaganda of the eleventh century has continued to influence our perception of the era. But the English were not the only ones engaged in the practice of using texts to further an agenda.

Both the Scandinavians, and later, the Normans, used historical narratives to advance the legitimacy of their ruling houses. The Encomium Emmae Reginae is an important source for the invasions of England by Swein Forkbeard and his son Cnut. Its purpose is to "glorify the Danish conquest of England" by presenting Cnut's struggle against Edmund Ironside as heroic. ${ }^{61}$ And while the Encomium "did not mention King Ethelred directly, the enhanced praise of King Edmund served to give added emphasis to the perceived failure of his predecessor." 62 Later, this propaganda would be layered over by Norman propaganda, as the Normans wished to emphasize the evil of King Edward's

\footnotetext{
${ }^{60}$ Howard, Swein Forkbeard's Invasions, 6.

${ }^{61}$ Howard, Swein Forkbeard's Invasions, 5.

${ }^{62}$ Howard, Swein Forkbeard's Invasions, 5.
} 
murder, thus explaining why God had allowed the Normans to conquer England. ${ }^{63}$

While the above examples were not unique, they serve to show that using various modes of writing for political purposes was very common in the period. It was this period in which Wulfstan wrote, and so it should not be surprising that nearly all of his works contain political agendas, and are directed to a political audience. While the Sermo Lupi can be regarded as an eschatological document calling for repentance, the fact that it was received by the ruling elite should change how we understand it. Wulfstan was not so much advancing theological arguments as he was advocating for political action. His works, even his homilies, were written to effect change and so are the very definition of advice literature as I conceive it. One primary difference in terms of style compared to earlier writers is that Wulfstan made much less effort to disguise his political writings, and openly used preaching for political purposes. Wulfstan escaped political backlash not by transporting his criticism onto distant exempla but by always writing in the abstract, never giving specific details. Nevertheless, we can localize the advice by contextualizing it within its political and historical contexts.

\section{Peace in Christendom, War Against Heathendom}

Like Bede, Wulfstan promoted the idea of an aggressively expansionist king; he differs, however, in that he directs that military action specifically against pagans. In the Institutes, Wulfstan declares: "sceal wis cyning cristendom and cynedom miclian and mærsian, and á he sceal hæpendom hindrian and hyrwan” [the wise king must glorify and enlarge Christendom and the kingdom, and he must always hinder and oppress

\footnotetext{
${ }^{63}$ Howard, Swein Forkbeard's Invasions, 6.
} 
Heathendom]. ${ }^{64}$ That Wulfstan advocates strong military action from the king is not a new concept. As demonstrated in Chapter 2, Bede was most concerned with the ability of a king to expand his domain and to generate wealth, and used as exempla kings who gained riches through war, such as Saul, David, and Æthelfrith. With Æthelfrith specifically, the Northumbrian king gained both gloria and spolia for his people, which was critical for continuing economic success. The fact that the Celts Æthelfrith was killing were Christian did not trouble Bede; in his view the Celts were a separate people [gens] and therefore a natural enemy of the Anglo-Saxons. Waging war for wealth, preferably against those ethnically distinct, was simply how kingship worked during Bede's era. By Wulfstan's time, these assumptions had shifted radically.

While raiding still formed the basis for many Scandinavian leaders such as Swein Forkbeard, it no longer held importance for English kings. As noted above, by Wulfstan's time England had become enormously wealthy through peace and trade. ${ }^{65}$ While raiding for wealth makes for good heroic poetry, it is ultimately a primitive economic form that is non-productive. That is, when the various Anglo-Saxon groups raided each other, it might benefit a particular king, but the net effect would be loss of wealth for England, since productive elements such as farms would be destroyed in the process. After England became more-or-less unified and peaceful, this economic hindrance stopped. By Wulfstan's time, war was more costly than peace. Therefore, for an English king to wage war, he needed an objective other than riches.

\footnotetext{
${ }^{64}$ Karl Jost, ed., Die 'Institutes of Polity, Civil and Ecclesiastical': Ein Werk Erzbischof Wulfstans von York. Swiss Studies in English 47. (Bern: A. Francke AG Verlag, 1959), II. Polity, 1. 15, p. 47. All Old English translations mine unless otherwise stated.

${ }^{65}$ Howard, Swein Forkbeard's Invasions, 14-16. That Æthelred was able to repeatedly make huge payments of silver to the Scandinavians is substantial proof of England's wealth during this time.
} 
Wulfstan advocates expanding the kingdom and Christendom, thus implicitly directing violence away from other Christians in a way that foreshadows the First Crusade. Wulfstan's concern with Christian-on-Christian violence would be echoed by Pope Urban II at the Council of Clermont in 1095: "I exhort and demand that you, each, try hard to have the truce kept in your diocese. And if anyone shall be led by his cupidity or arrogance to break this truce, by the authority of God and with the sanction of this council he shall be anathematized." ${ }^{\prime 66}$ Not only was fighting amongst Christians condemned, but those who broke the peace were threatened with being cast out from Christian community. Of the three types of excommunication, anathema was the most severe; it could only be pronounced by the Pope, and only for "crimes of the gravest order." ${ }^{97}$ This declaration alone created a very strong in-group mentality. Essentially, Urban declared that all Christians were part of the same group and to violate the group meant exile. While this type of thinking was not new, during earlier periods we often see it applied to smaller communities and kin-groups rather than to all Christians. In this very same council, Urban announced his call for the First Crusade. ${ }^{68}$ So while the strongest of ecclesiastical punishments were threatened against those who did violence on Christians, this violence was being redirected to those outside of Christendom. For those who lived by the sword, their options had been severely limited.

Like Pope Urban II, Wulfstan condemns Christians doing evil to other Christians, but the situation was somewhat different than the internecine warfare (especially in

\footnotetext{
${ }^{66}$ Paul Halsall, ed., "Urban II: Speech at Council of Clermont, 1095, According to Fulcher of Chartres." In Internet Medieval Sourcebook. Fordham University Center for Medieval Studies, 1997. https://sourcebooks.fordham.edu/source/urban2-5vers.html.

${ }^{67}$ Joseph Gignac, “Anathema." The Catholic Encyclopedia (New York: Robert Appleton Company, 1907), http://www.newadvent.org/cathen/01455e.htm.

${ }^{68}$ Halsall, "Urban II: Speech at Council of Clermont"
} 
France) that Urban was condemning. During the tenth and eleventh centuries, France underwent a lot of fragmentation and internal fighting as the crown weakened; by contrast, England became increasingly centralized during this same period. ${ }^{69}$ England faced more external threats, which served to unify it, while France had mostly repelled and contained its external threats, leaving soldiers with no one to fight but each other. ${ }^{70}$ It is for this reason that the First Crusade was mostly a French enterprise; few AngloSaxons joined the call. ${ }^{71}$ During the eleventh century, England did not suffer from having too many fighting men. In fact, quite the opposite seems to have been the case, and this is largely the reason that Æthelred was repeatedly forced to pay for truces: he did not have an army strong enough (or loyal enough) to repel the Scandinavians. ${ }^{72}$ So what we see Wulfstan condemning in the Sermo Lupi is not the rapacious behavior of bored soldiers, but rather a general lawlessness and lack of justice:

unrihta to fela rixode on lande; 7 næs a fela manna pe hogade ymbe pa bote swa georne swa man sceolde, ac dæghwamlice man ehte yfel æfter oðrum 7 unriht rærde 7 unlaga manege ealles to wide geond ealle pas ðeode. $^{73}$

[too many injustices rule in the land; and there were not many people who

${ }^{69}$ Damon, "Sanctifying Anglo-Saxon Ealdormen," 189.

${ }^{70}$ Damon, "Sanctifying Anglo-Saxon Ealdormen," 189. Not only did this lead to endless fighting, but various religious responses, such as the Peace of God and the Truce of God.

${ }^{71}$ Damon, "Sanctifying Anglo-Saxon Ealdormen," 188. From England, the Normans were moderately more involved, owing to their ties with France. There were a few notable Anglo-Saxon exceptions however, including Edgar the Ætheling (nephew of Edward the Confessor) and Robert FitzGodwin (Godwinson).

${ }^{72}$ The reasons for this are complex, but in my estimation have most to do with the long peace that existed since the time of Edgar. Even as early as 991 there would have been a shortage of experienced fighting men. By contrast, the constant raiding and in-fighting among the Scandinavians created a large group of hardened warriors.

${ }^{73}$ Bethurum, The Homilies of Wulfstan, mss. BH, 11. 8-12, p. 255. 
thought about the solution as carefully as one ought, but daily people pursue one evil after another and lift up injustice and many violations of the law all too widely throughout all this kingdom.]

Where Urban condemned the "cupidity" for war, Wulfstan sees injustice [unriht $]$ as the primary issue causing fragmentation and chaos among Christians. While Wulfstan does in many places complain about the assaults of the Scandinavians, the unriht he complains about seems to be a problem inherent in England itself. More specifically, it is a problem with those who rule, as it is they, and especially the king, who are charged with keeping justice in the land. As this homily was written in anticipation of Swein's coronation, the idea seems to have been that Wulfstan wanted Swein to do a better job of governing than his predecessor, Æthelred. As always, however, he is careful to avoid attaching blame or giving advice directly. The reality is that Swein's attacks contributed significantly to the general disarray the kingdom was in. So Wulfstan complains about the behavior of the heathen Scandinavians, but avoids putting any blame directly upon Swein.

Wulfstan gives us two different solutions to the problem of unriht within Christendom. In the Institutes, he places the responsibility upon both Christ and king, while in the Sermo Lupi, he seems to advocate for a general repentance. Here I will focus on his position within the Institutes, as it represents Wulfstan's more fully developed political vision, as opposed to the Sermo Lupi, which was more of an ad hoc homily. ${ }^{74}$

In the Institutes, Wulfstan eschews the connection between repentance and justice seen in the Sermo Lupi, instead identifying justice as the king's duty to God and people.

\footnotetext{
${ }^{74}$ That is not to say that the Sermo Lupi has no larger or generalized ideas, but only that in it Wulfstan's ideas were shaped for a particular political moment, whereas the Institutes better represents his life's work on political organization.
} 
He outlines the situation thus:

La, purh hwæt sceal Godes peowum and Godes pearfum frið and fultum cuman butan purh Crist and purh cristenne cyning? Purh unwisne cyning folc wyrð geyrmed for oft, næs æne, for his misræde. ${ }^{75}$

[Lo, through what means shall peace and help come to God's servants and God's needy ones except through Christ and through a Christian king? Through an unwise king the people will become wretched, not once, very often, because of his misguidance.]

Wulfstan is advocating a solution that is essentially Eusebian. As I argued in Chapter 1, Eusebius understood the role of the monarch to be closely linked to that of Christ. The monarch was a partner with Christ in the government of the earthly kingdom, a "second savior" $" 76$ of sorts, where God worked through "two coordinate powers in Heaven and on earth." ${ }^{.77}$ Wulfstan emphasizes this worldview in the Institutes, where his first two sections are titled "be heofonlicum cyninge" [about the heavenly king] and "be eorðlicum cyninge" [about the earthly king]. ${ }^{78}$ Elsewhere in the Institutes, Wulfstan describes the king's duty in this matter: "eal cristen folc sibbige and sehte mid rihtre lage, swa he geornost mæge, and purh ælc ping rihtwisnesse lufie for Gode and for worolde. ${ }^{79}[\mathrm{He}$ shall bring peace and settle disputes for all Christian folk through just law, as carefully as he is able, and in all things love justice before God and the world.] The administration of justice is a king's duty to both God and his people, and essential to the stability of

\footnotetext{
75 Jost, Die Institutes of Polity, II. Polity, 11. 12-13, pp. 46-47.

${ }^{76}$ Stringer, "The Political Theology of Eusebius Pamphili, Bishop of Caesarea," 138.

${ }^{77}$ Drake, In Praise of Constantine, 57.

${ }^{78}$ Jost, Die Institutes of Polity, II. Polity, pp. 39-41.

${ }^{79}$ Jost, Die Institutes of Polity, II. Polity, 1l. 6-6a, pp. 43.
} 
Christendom. If he fails in this task, due to misrced [misguidance or evil advice], the people will suffer. Wulfstan makes clear in the above passage that even if a king receives misrced, he must have the wisdom to choose justly. For Wulfstan, who was an important advisor himself, the ultimate responsibility lies with the king and not with the advisors. Unfortunately, Æthelred was not a very decisive king, and wavered between competing advice.

Æthelred received conflicting advice about how to establish peace in Christendom and prevent the ravages of the Scandinavians, and he continually wavered between the two. As John Edward Damon notes, "One might be more exact in calling him 'ofer-ræd' than 'unræd': a man of too many counsels rather than none." ${ }^{80}$ Damon outlines two main factions advising Æthelred during the critical period of 991-1016: one faction continually advised the king to make peace with the Scandinavians, with the hope that they could be converted to Christianity; the other side advocated for vigorous military action against the invaders ${ }^{81}$ Wulfstan was clear in his advocacy for war in his writings, declaring in the Institutes, for example, that the king must "eallum Godes feondum styrnlice wiðstandan" ${ }^{22}$ [harshly resist all God's enemies]. Opposing Wulfstan was the peace faction, which included a mix of ecclesiastical and secular figures: Sigeric, Archbishop of Canterbury, Ælfheah, Bishop of Winchester, Ealdorman Ethelward, and Ealdorman Ælfric. ${ }^{83}$ Those who sought to convert the invaders were not without some precedent. After all, Guthrum converted and made peace with King Alfred as part of their

\footnotetext{
${ }^{80}$ Damon, "Advisors for Peace in the Reign of Æthelred Unræd," 75.

${ }^{81}$ Damon, "Advisors for Peace in the Reign of Æthelred Unræd," 58.

${ }^{82}$ Jost, Die Institutes of Polity, II. Polity, 1. 9, p. 45.

${ }^{83}$ Damon, "Advisors for Peace in the Reign of Æthelred Unræd," 61, n. 12.
} 
settlement. And Olaf Tryggvason agreed to convert when King Æthelred made peace with him. ${ }^{84}$ Still, Wulfstan would have likely considered this advice to be misrced, as noted above — bad advice that if listened to would lead to injustice. History, it would seem, would prove Wulfstan correct, as all attempts to buy peace with the Scandinavian forces only encouraged further invasions until Æthelred himself was driven from his kingdom.

The rampant disloyalty during Æthelred's reign provided Wulfstan with a major theme for his Sermo Lupi, where he promotes loyalty as essential to a stable Christendom. This disloyalty was rampant among those belonging to the peace faction, and the behavior of Ealdorman Ælfric is especially egregious. In 992, after the Battle of Maldon, the king sought to take naval action against the Scandinavians:

Đa gerædde se cyng 7 ealle his witan pet man gegaderode pa scipu pe ahtes wæron to Lundenbyrig, 7 se cyng pa betæhte pa fyrde to lædene Ealfrice ealdorman 7 Porode eorl 7 Ælfstane biscop 7 Æscwige biscop, 7 sceoldan cunnian gif hi muhton pone here ahwær utene betræppen. Đa sende se ealdorman Ælfric 7 het warnian pone here, 7 pa on pere nihte ðe hi on ðone dæi togædere cumon sceoldon, ða sceoc he on niht fram pære fyrde him sylfum to mycclum bismore, 7 se here pa ætbærst, buton an scip pær man ofsloh. ${ }^{85}$

[Then the king and all his witan determined that they should gather

${ }^{84}$ Damon, "Advisors for Peace in the Reign of Æthelred Unræd," 62.

${ }^{85}$ Irvine, The Anglo-Saxon Chronicle, [992], p. 61. 
together all the ships they had to London, and the king gave leadership of the army to Ealdorman Ælfric, Earl Thored, Bishop Ælfstan, Bishop Æscwig, that they should attempt, if they are able, to entrap the enemy forces somewhere without. Then the Ealdorman Ælfric sent and warned the enemy forces, and on the night before the day in which they should come together to fight, he snuck himself away from the army, to great disgrace. And the enemy then escaped, except one ship, whose crew were slain.]

Although the $A-S$ Chronicles declares the naval expedition to have been a decision of the witan, it is clear that there were those in the witan who would have opposed military action, including Ælfric. It is hard to imagine why Æthelred would make Ælfric a leader of a mission he opposed, but it does help to explain Ælfric's behavior. The betrayal of Æthelred's military plans was endemic during the period, and his followers show a shocking lack of loyalty to him. Ælfric is not an outlier here. In 993 Æthelred assembled a "mycele fyrde" [great army] to fight against the Scandinavians, but the generals fled the field. ${ }^{86}$ In 999 the king assembled both a large army and fleet, but for whatever reason this force never engaged the enemy; Æthelred's military leaders give the impression of having some combination of cowardice, incompetence, and disloyalty. The $A-S$ Chronicles are quite critical concerning the 999 military assembly: "ponne æt pam ende ne beheold hit nan ping seo scipfyrding buton folces gewwinc 7 feos spilling 7 heora feonda forðbylding." ${ }^{87}$ [Thus in the end the navy accomplished nothing except to afflict

\footnotetext{
${ }^{86}$ Irvine, The Anglo-Saxon Chronicle, [993], p. 61.

${ }^{87}$ Irvine, The Anglo-Saxon Chronicle, [999], p. 63. It is interesting to note that the authors of the $A-S$ Chronicles seem to have been almost entirely of the war faction, and have little good to say about those
} 
the people, waste their wealth, and embolden their enemies.] In 1003 Æthelred assembled another force, and incomprehensibly put Ealdorman Ælfric in charge of it. Still unwilling to fight, Ælfric pretended to be sick and retreated the forces ${ }^{88}$ While Æthelred had seasoned councilors such as Wulfstan at his disposal, he clearly also placed his trust in those not fully committed to serving him. ${ }^{89}$ Wulfstan understood that this lack of loyalty was destroying the nation and that the peace faction would lead only to further war and chaos, as the Scandinavians would not be sated with peace payments.

\section{For King and Country}

Wulfstan pushed against the peace faction and advocated for loyalty to the king, especially in his Sermo Lupi. This is a telling position for Wulfstan to take, considering his own doubts concerning Æthelred's capabilities, as noted earlier. For Wulfstan, however, what was most important was the maintenance of stable social order. He advocated for the Anglo-Saxons to stand and fight against the invading Scandinavians, and opposed the payment of tribute. His position is remarkably constant with the viewpoint advocated in the anonymous poem, The Battle of Maldon. ${ }^{90}$ The leader of the Anglo-Saxon forces, and the hero of the poem, was Byrhtnoth, ealdorman of Essex. The poem narrates how a band of Vikings show up on the shores of Essex in 991 A.D. and are met by the defending forces of Byrhtnoth. The Vikings promise peace if they are paid, a

in the peace faction.

${ }^{88}$ Irvine, The Anglo-Saxon Chronicle, [1003], p. 64.

${ }^{89}$ Roach, Athelred the Unready, 314. As Roach makes clear, there were other rivalries aside from the war and peace factions discussed here. Some of these rivalries were long-standing and dated back to the reign of Edgar the Peaceful (r. 959-975).

${ }^{90}$ For recent scholarship, see: Donald Scragg, ed., The Battle of Maldon, AD 991 (Oxford: B. Blackwell in association with the Manchester Centre for Anglo-Saxon Studies, 1991); and Idem, The Return of the Vikings: The Battle of Maldon 991 (Stroud: Tempus, 2006). 
notion that Byrhtnoth defiantly rejects:

Gehyrst pu, sælida, hwæt pis folc segeð?

Hi willað eow to gafole garas syllan, ætrynne ord and ealde swurd,

pa heregeatu pe eow æt hilde ne deah.

Brimmanna boda, abeod eft ongean, sege pinum leodum miccle lapre spell, pæt her stynt unforcuð eorl mid his werode, pe wile gealgean epel pysne, Æpelredes eard, ealdres mines, folc and foldan. Feallan sceolon hæpene æt hilde. To heanlic me pinceð pæt ge mid urum sceattum to scype gangon unbefohtene, nu ge pus feor hider on urne eard in becomon.

Ne sceole ge swa softe since gegangan; us sceal ord and ecg ær geseman, grim guðplega, ær we gofol syllon ${ }^{91}$ [Do you hear, seaman, what this people says? They plan to give you naught but spears for tribute, Poisonous point and edge of tried old sword,

${ }^{91}$ Elliott Van Kirk Dobbie, ed., "The Battle of Maldon.” In The Anglo-Saxon Minor Poems, 7-16. AngloSaxon Poetic Records 6. (New York: Columbia University Press, 1942), 1. 45-61. 
War-tax that will not help you in the fight.

Go, viking herald, answer back again,

Tell to your men a much more hostile tale:

Here stands an earl undaunted with his troop,

One who intends to save this fatherland,

Ethelred's kingdom, and my liege lord's land

And people. It shall be the heathen host

That falls in fight. It seems to me too shameful

That you should take our tribute to your ships

Without a fight, now that you have advanced

So far onto our soil. You shall not win

Treasure so easily; but spear and sword

Must first decide between us, the grim sport

Of war, before we pay our tribute to you. $]^{92}$

Byrhtnoth, as least in the Maldon poet's representation, rejected the buying of peace, a prospect that he finds shameful. He openly declares his loyalty to Æthelred, his king and to the Anglo-Saxon land and people. It is a mindset that Wulfstan would have vigorously approved of. While I have seen no evidence connecting the Maldon poet to Wulfstan, both of these figures at the very least belonged to the same faction. The Maldon poet ridicules those who would pay money rather than fight and promotes a concept of absolute loyalty.

${ }^{92}$ Translation from Richard Hamer, ed., "The Battle of Maldon.” In A Choice of Anglo-Saxon Verse, 48-69. (London: Faber \& Faber, 1970), 53. 
The extraordinary loyalty demonstrated in The Battle of Maldon echoes an older heroic mythos, but at the same time represents a new conception of political organization that Wulfstan advocated for. What is so unusual in the loyalty demonstrated in Maldon is that some of Byrhtnoth's men choose to stay on the battlefield and fight unto the death even after their leader had died and there was no real hope for victory: "Рa ðær wendon forð wlance pegenas, unearge men efston georne: hi woldon pa ealle oðer twega, lif forlætan oððe leofne gewrecan" [Then proud thanes came forward there, the undaunted men hastened eagerly: they all wanted one of two things, to give up their life or to avenge their beloved lord]. ${ }^{93}$ While taking revenge for either kin or one's lord was a common aspect of wergild in Anglo-Saxon society, simply seeking death was not. Some scholars, such as Dorothy Whitelock, see no break in the comitatus practices described by Tacitus in the first century and the events portrayed in Maldon in the late $10^{\text {th }}$ century. ${ }^{94}$ Tacitus claimed that "infamy and lifelong scandal await the man who outlives his leader by retreating from the battle-line. ${ }^{95}$ However, there is no evidence of this practice being the norm in Anglo-Saxon England. There are no other accounts besides Maldon of a troop of Anglo-Saxon warriors sacrificing themselves due to the death of their lord. There is no reference to this even among the Latin historians of England, who often drew upon popular heroic legends. ${ }^{96}$ The closest Anglo-Saxon analogue is the Cynewulf and Cyneheard episode in the Anglo-Saxon Chronicle, where warriors are not choosing between fighting to the death or strategic retreat, as Byrhtnoth's men are, but rather are rejecting an offer

\footnotetext{
${ }^{93}$ Elaine Treharne, "The Battle of Maldon," In Old and Middle English c.890-c.1400: An Anthology. (Malden, MA: Blackwell, 2004), 11. 205-8. Translation is Treharne's.

${ }^{94}$ Whitelock, The Beginnings of English Society, 29-38.

${ }^{95}$ Cornelius Tacitus, Germania. Edited by J. B. Rives. Clarendon Ancient History Series. (Oxford: Oxford University Press, 1999), 14.1.

${ }^{96}$ Woolf, "The Ideal of Men Dying with Their Lord," 72.
} 
between fighting or serving the killer of their lord ${ }^{97}$ In this case their duty as their lord's comitatus is clear and their actions, while certainly heroic, are not strange. I agree with Rosemary Woolf, who argues that while the outcomes seem similar, they are actually different circumstances. ${ }^{98}$ This leaves the episode in Maldon as a unique event.

Byrhtnoth's men are not drawing on traditional expectations for a comitatus in their suicidal last stand. As Woolf argues, "there is no evidence that the obligation of a retainer to die with his lord was a pervasive ideal in Germanic society which could well have lived on into tenth-century English life or literature." ${ }^{99}$ Stephen Harris's work on the oaths of retainers to their lord supports the idea that Maldon is drawing mostly on later Anglo-Saxon ideas of loyalty, as traditionally an oath of loyalty did not move up the chain of command, but rather was localized to a specific war leader. ${ }^{100}$ This is relevant to Maldon in that once Byrhtnoth is dead, the men are no longer under obligation to fight, unless one considers that they are bound to the king, the country, or something other than Byrhtnoth himself. Roberta Frank concludes that the heroic deaths in Maldon look "not backward through the mists to Germania, but just around the corner, to an eleventhcentury Europe in which the profession of warrior was a way of achieving religious perfection and a martyr's crown." ${ }^{101}$ This new sense of loyalty extending beyond just a local lord, and extending to the distant king and to the country itself, shows that the poet,

\footnotetext{
${ }^{97}$ Woolf, "The Ideal of Men Dying with Their Lord," 70.

${ }^{98}$ Woolf, "The Ideal of Men Dying with Their Lord," 70.

${ }^{99}$ Woolf, "The Ideal of Men Dying with Their Lord," 70-80. Woolf ultimately tries to find a link in the Bjarkamal, an Old Norse poem in which a band of retainers die after their leader is killed. This explanation is tenuous, and made more so by Roberta Frank's assertion that the Bjarkamal dates from the twelfth century, far after The Battle of Maldon was composed (Frank, "The Ideal of Men Dying with Their Lord," 98-99).

${ }^{100}$ Harris, "Oaths in The Battle of Maldon," 100.

${ }^{101}$ Frank, "The Ideal of Men Dying with Their Lord," 106.
} 
at least, was thinking about the organization of society in new ways. His depiction of Christian warriors dying and fighting to protect Christendom, regardless of whether or not they were bound by old oaths of loyalty, echoes the concerns with loyalty and the defense of Christendom that we see in the writings of Wulfstan.

Wulfstan's concerns about loyalty were tied to the trauma of Edward the Martyr's murder in 978 . While the reasons for the king's murder are not altogether clear, the $A-S$ Chronicles are absolute in its condemnation of the deed: "Ne wearð Angelcynne nan wærsa dæd gedon ponne peos wæs syððon hi ærest Brytonland gesohton.”"102 [No worse deed for the English was ever done than this was, since they came to the land of Britain]. ${ }^{103}$ Whether or not Wulfstan had a hand in the Chronicle's language, he reflects the sentiment in the Sermo Lupi and connects it to the greater problem of disloyalty: Forðam syn on lande ungetreowða micel for Gode and for worulde, 7 eac her syn on earde on mistlice wisan hlafordswican manige. And ealra mæst hlafordswica se bið on worulde pæt man his hlafordes sawle beswice; 7 ful micel hlafordswica se bið on worulde pæt man his hlaford on life beswice oððon of lande lifigende drife, 7 ægðer is geworden on pyssan earde:

Eadweard man forrædde 7 syððan acwealde 7 æfter pam forbærnde. ${ }^{104}$ [Therefore, there are great disloyalties towards God and towards the world throughout the land, and also there are here within the land those who are traitors to their lord in many various ways. And of all the treachery in the

\footnotetext{
102 Irvine, The Anglo-Saxon Chronicle, [979], p. 60.

${ }^{103}$ Translation from Garmonsway, The Anglo-Saxon Chronicle, 123.

${ }^{104}$ Bethurum, The Homilies of Wulfstan, 257-58.
} 
world to the lord the greatest is that a man should betray his lord's soul; and it is also a very great betrayal of one's lord in the world that a man should treacherously kill his lord or drive his lord, living, from the land. And both have happened in this land: Edward was betrayed and afterwards killed and afterwards he was burned. $]^{105}$

This was the text that was written for the witenagemot of 16 February 1014, which, as noted above had intended to crown Swein Forkbeard after Æthelred II had been driven from the kingdom. ${ }^{106}$ While Wulfstan accepts that Swein will be crowned king, he is also obliquely critical here of those who did not stand up for Æthelred, who was the king driven from the land. But Wulfstan also reminds his audience that Æthelred only became king due to the murder of his brother, Edward. There remained for Wulfstan, and for those after, a permanent stain upon the reign of Æthelred, due to regicide that led to his accession. When Swein unexpectedly died, the witan recalled Æthelred back instead, "gif he hi rihtlicor healdan wolde ponne he ær dyde." ${ }^{107}$ [if he would rule them more justly than he did before]. The situation must have been frustrating for Wulfstan, who advocated strongly for strict social stability in his Institutes, to have to decide between a foreign conqueror or a king who was crowned under suspicious circumstances, and who did not manifest order or loyalty within his kingdom. Still, Wulfstan stood by his principles in recalling Æthelred, and like Byrhtnoth remained true to his native lord even when it

\footnotetext{
105 Translation from Elaine M. Treharne, "Wulfstan's Sermo Lupi Ad Anglos." In Old and Middle English c. 890-c.1400: An Anthology, 226-33. (Malden, MA: Blackwell, 2004), 229. Wulfstan here is rather more specific than usual. This can be explained in that there was nothing controversial in writing about the death of Edward, as this was a tramatic event in England's past that was felt by all. He does, however, quickly pass over the lord who was driven from the land, and neglects to mention Æthelred by name.

106 Wilcox, "Wulfstan's Sermo Lupi ad Anglos as Political Performance," 376.

${ }^{107}$ Irvine, The Anglo-Saxon Chronicle, [1014], p. 71.
} 
might have seemed better not to.

\section{Conclusion}

Wulfstan was in some ways in a position similar to Bede. Wulfstan advocated strongly for an aggressively military policy but was faced with a king who only partially followed his advice. It must be remembered that although Wulfstan was an influential voice, Æthelred had other councilors as well whom he listened to. One of the major problems with Æthelred's reign was that his advisors were divided between a peace faction and a war faction. As has been seen, even when Æthelred attempted to implement military action, those in the peace faction worked to subvert these efforts. What is not entirely clear is why Æthelred tolerated such disloyalty from his advisors. Altogether, he seemed to be an indecisive ruler, and a poor judge of character. He would not be the first king to be undone by poor advice. That his advisors held so much power in public decision making demonstrates how critical the witan had become by the eleventh century, and how influential these advisors could be.

Wulfstan envisioned a Holy Society where the king was not the ruler over a kingroup, but rather over a piece of Christendom. His duties were to maintain order and loyalty and to rally his men against heathens. In the Institutes he detailed and advocated for a society organized into the Three Estates: soldiers, priests, and workers. On top of these three pillars, and supported by them stood the throne of the king. ${ }^{108}$ This was an organization that Wulfstan's friend Ælfric also strongly promoted. ${ }^{109}$ In Wulfstan's

\footnotetext{
108 Jost, Die Institutes of Polity, II. Polity, 1. 31-40, p. 55-58.

${ }^{109}$ Walter W. Skeat, ed., Aelfric's Lives of Saints: Being a Set of Sermons on Saints' Days Formerly Observed by the English Church. Vol. 2. (London: Published for the Early English Text Society by
} 
conception, the king did not belong to any of the Estates, but stood above all of them, as one who united the cross and the sword. As with Bede, Wulfstan was not altogether successful in seeing his vision implemented this notion of king as holy war leader would be fully embraced later in the eleventh century by those who led the First Crusade.

Kegan Paul, Trench, Trübner \& Co, 1900), 2.812-18: “Is swa-ðeah to witenne pæt on on pysre worulde synd preo endebyrdnysse on annysse gesette pæt synd laboratores oratores bellatores laboratores synd pa pe urne bigleafan beswincað oratores synd pa ðe us to gode geðingiað bellatores synd pa ðe ure burga healdað and urne eard be-weriað wið onwinnendne here.” [It is, however, to wit, that in this world there are three orders, set in unity, these are-labourers, beadsmen, soldiers. Labourers are they who obtain with toil our subsistence; Beadsmen are they who intercede with God for us; Soldiers are they who protect our towns, and defend our soil against an invading army.] 


\section{CONCLUSION}

Oddly enough, this project began with Beowulf. Through teaching and studying that marvelously elusive text over several years, I became drawn to the many kings portrayed in it, and became obsessed with trying to understand what the author considered a god cyning. While the kings upheld were generally admirable figures, such as Hrothgar and Beowulf, they also demonstrated such distinct models of kingship that it was difficult to understand any consistent underlying criteria. One could admire a passive philosophical king or a fearless warleader, but what qualities did they share, if any? Originally, it was in trying to answer this question that I turned to those Anglo-Saxon writers who thought most about kings. What I discovered was a rich tradition of writing that was fascinating in itself, and which (as is invariably the case) presented its own set of questions and problems.

The narrative of advice literature, as I have traced it, ranges from the rise of David under the guidance of Samuel down to the political maneuvering of Wulfstan during the reign of Æthelred. In approaching a topic with such a sweeping history, many details have, of necessity, been passed over. Likewise, many ecclesiastical figures and kings have not entered this work that, given infinite time and space, could fruitfully be considered within this framework. However, by looking at important moments within the expanse of time considered, we can sketch out a mode of writing and a development of thought that permeated Christian medieval texts. It was a tradition that drew upon, at different times, late Roman ideas and Old Testament models for the organization of 
society.

Advice literature was a mode of writing that was under constant development, as was the theoretical model of kingship itself. In terms of Christian political thought, it was a tradition that began with Eusebius, who was the first to envision a Christian polity centered on an earthly monarch. While not all of his Platonism was adopted by later writers, his elevation of the earthly king to a sacral position, as one who held a salvific role for his subjects, would continue to be a key concept to numerous later authors. Likewise, Gildas's blending of history, homily, and Old Testament exempla would serve to be a common method of presenting political concepts. It allowed the writer to draw upon the authority of both cultural memory and Scripture, two elements that often bound together medieval communities. These writers used the power of faith and kin to transform tribal monarchs into Christian kings.

A king in Anglo-Saxon England had to stand between two realms: the earthly and the heavenly. This was the model of kingship that Eusebius envisioned, with the monarch's realm mirroring God's heavenly kingdom. But it was a precarious balance to maintain. While many ecclesiastics throughout the early medieval period struggled to Christianize semi-pagan warlords, Bede was in the somewhat awkward position of showing the value of military violence to king who was more comfortable in the monastery than in the shieldwall. Bede had good reason to lavishly recount the exploits of heroic military figures, for without warriors who were willing to shed blood, monastics like Bede would be choice targets for reavers, as indeed was the case during much of the Anglo-Saxon period. For Bede, Oswald was paragon of kingship because this king was a holy warrior who embodied the spirit of his people. This concept of the holy warrior is 
not really a new one (it is, in many ways, quite ancient), but it was one that took time to develop within Christianity. It was an idea that would eventually become ubiquitous in the later medieval period with the concept of holy knighthood.

The balance between sacred and earthly matters was realized in Asser's vision of Alfred. In his account, Asser is critically aware of the need to balance the physical and spiritual aspects of his king. He highlights moments of intellectual and spiritual activity that alone would present Alfred as an ascetic, saintly figure. To counterbalance this hagiographic trend, Asser draws upon traditional heroic imagry and language to describe Alfred's military and hunting exploits. He masterfully blends these elements in his image of Alfred, solidifying his monarch as a paragon of Christian kingship. Alfred's many realworld accomplishments aside, Asser's vision has contributed greatly to the perception of Alfred as a near perfect king.

This vision of kingship had not changed much by the eleventh-century, as evidenced by the writing of Wulfstan. The bishop's emphasis on Christendom and holy war was really a natural development of ecclesiastical thought concerning kingship. Of course, by Æthelred's reign, the role of king had become much more complicated than it had been during Alfred's time. The country was larger, more populated, with a more advanced economy. There was also divided opinion on how a Christian king should deal with aggressive pagans, with one camp advocating for peaceful conversion and the other pushing for aggressive holy war. This concept of kings as Christian generals who advance Christianity through military means was not wholly new. Charlemagne pursued a program of military conversion with neighboring pagans. But the eleventh century would later see the Church actively sanctify such endevors with a fervor hitherto unknown. 
The Anglo-Saxon period was dynamic in terms of political thought and authorial technique. While Anglo-Saxon poetry is often conservative in its adherence to traditional modes, it would be a mistake to be lulled by poetic artistry into believing that the period itself was static and that its authors were not actively developing their craft. My research helps us to better understand the development of Anglo-Saxon political thought and culture, and to connect it to larger European trends.

As discussed in my introduction, there has been a growing interest among literary scholars in connecting various modes of writing to the political contexts in which they were produced. This scholarship has been directed at both "literary" and "non-literary" works, including homilies, poetry, hagiography, and other genres. This scholarship, including my own, show that Anglo-Saxon authors had a deep sense of providential history and were concerned with positioning themselves within a larger world. They considered models such as Old Testament figures, but also blended their own heroic traditions to create a complex vision of society that we can only partially reconstruct and understand. This vision of society was not static, but rather developed over the period in response to challenges the Anglo-Saxons faced. At the same time, it drew on transcendent theological and cultural ideals, aspects of which were emphasized and enacted to greater and lesser degrees at different periods.

While I have not yet returned to the origins of this project and applied my research into advice literature to Beowulf, I have little doubt that it would at least shed some light onto the author's idea of a god cyning. Like Bede, the author of Beowulf was using narrative and exemplarity to model behavior. In fact, the Beowulf author was 
himself giving political advice when he declared "Pæt wæs god cyning."1 The author's commentary comes at small moments and is subtle, but is there nonetheless. The Beowulf poet, like many of the writers I have examined, preferred to let narrative do most of the work. There is still much to be done in terms of exploring Anglo-Saxon works in regard to advice literature, exemplarity, and political context. Many Anglo-Saxon works touch on issues of kingship or political organization. Aside from Beowulf, The Battle of Maldon, and The Anglo-Saxon Chronicles (which I have discussed), many saints' lives have political subtexts and were recycled at certain historical moments due to contemporary concerns. Biblical translations are also often laced with political motivations. Alfred's translation of the Psalms was the meditations of a king translated by another king, and much of the material there was timely to Alfred's reign, a quality that is shared by all of the Alfredian corpus. Most of all, other ecclesiastical writing, such as the many works of Ælfric of Eynsham, can still be further explored in terms of political context. Overall, Anglo-Saxon writers were a politically conscious group with complex ideas about how to secure God's blessings while simultaneously meeting the practical needs of the day. They embraced a worldview that blended politics, religion, and native tradition in ways that defy neat separation, and this worldview permeated their poetry and prose. By understanding the political theology of the Anglo-Saxons, we create a foundation upon which to better understand Anglo-Saxon language, culture, and literature.

\footnotetext{
${ }^{1}$ Klaeber, Beowulf, 1. 11.
} 


\section{Appendix I}

\section{Images from the Stuttgart Psalter ${ }^{2}$}
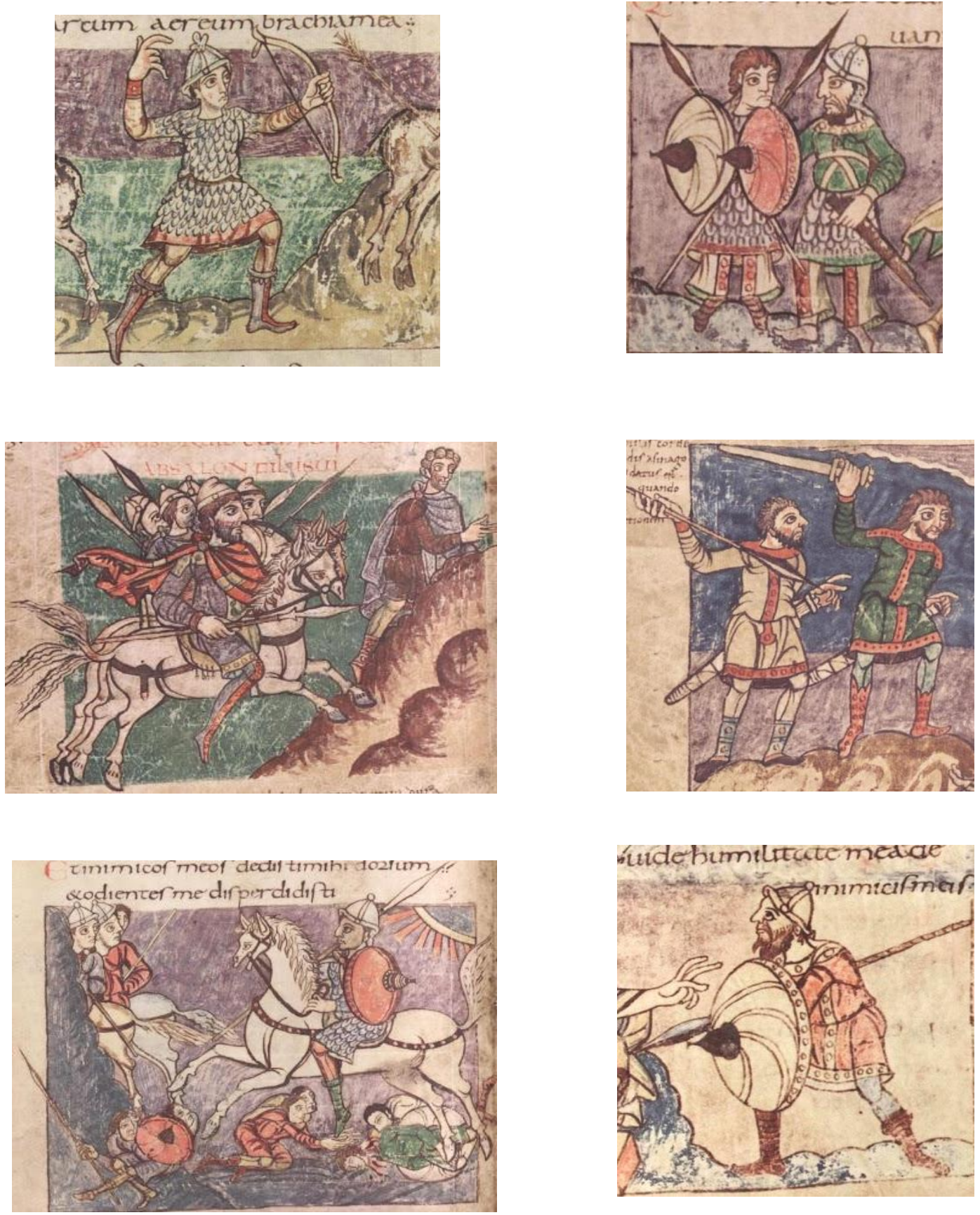

${ }^{2}$ All images here taken from Stuttgarter Psalter. Württembergische Landesbibliothek. Accessed February 24, 2017. http://digital.wlb-

stuttgart.de/sammlungen/sammlungsliste/werksansicht/?no_cache=1\&tx_dlf\%5Bid $\% 5 \mathrm{D}=1343 \& t x \_d l f$ $\% 5$ Bpage $\% 5 \mathrm{D}=1$. 


\section{BIBLIOGRAPHY}

The following list includes all works that I have consulted during my research that have shaped my thinking, including sources not directly cited.

Abels, Richard Philip. Alfred the Great: War, Kingship, and Culture in Anglo-Saxon England. Harlow, England; New York: Longman, 1998.

Abels, Richard. “"The Crimes by which Wulfbald Ruined Himself with His Lord': The Limits of State Action in Late Anglo-Saxon England." Reading Medieval Studies 40 (2014): 42-53.

Ackroyd, Peter R., ed. The First Book of Samuel. Cambridge: Cambridge University Press, 1971.

Almond, Richard. Medieval Hunting. Stroud: Sutton, 2003.

Amodio, Mark. The Anglo-Saxon Literature Handbook. Blackwell Literature Handbooks. Chichester, West Sussex: Wiley-Blackwell, 2014.

Anderson, Rachel S. “Ælfric’s Kings: Political Hagiography in Anglo-Saxon England.” Diss., Indiana University, 2004.

Augustine [of Hippo]. The City of God against the Pagans. Edited by R. W. Dyson. Cambridge: Cambridge University Press, 1998.

. "Letter 189." In Nicene and Post-Nicene Fathers, First Series, edited by Philip Schaff, translated by J.G. Cunningham, Vol. 1. Buffalo, NY: Christian Literature Publishing Co., 1887. http://www.newadvent.org/fathers/1102189.htm. [Revised and edited for New Advent by Kevin Knight, 2009.]

Bagge, Sverre. The Political Thought of the King's Mirror. Odense: Odense University Press, 1987.

Bailey, Maggie. “Ælfwynn, Second Lady of the Mercians.” In Edward the Elder 899-924, edited by N. J Higham, 112-27. Abingdon, UK: Routledge, 2001.

Baldick, Chris. "exemplum." In The Oxford Dictionary of Literary Terms. Oxford University Press, 2015. Accessed July 5, 2017.

http://www.oxfordreference.com/view/10.1093/acref/9780198715443.001.0001/a cref-9780198715443-e-429. 
Barnes, Timothy David. Constantine and Eusebius. Cambridge, Mass.: Harvard University Press, 1981.

Barrow, Julia. "Demonstrative Behaviour and Political Communication in Later AngloSaxon England." Anglo-Saxon England 36 (2007): 127-50.

Baynes, Norman. "Eusebius and the Christian Empire." In Byzantine Studies and Other Essays, edited by Norman Baynes. London: Althone Press, U of London, 1955.

Bede. In Primam Partem Samuhelis Libri IIII. In Bedae Venerabilis Opera, edited by David Hurst. Corpus Christianorum. Series Latina. Turnholti: Typographi Brepols, 1955.

Bejczy, István P., and Cary J. Nederman, eds. Princely Virtues in the Middle Ages, 12001500. Disputatio 9. Turnhout: Brepols, 2007.

Blake, E. O. Liber Eliensis. London: Office of the Royal Historical Society, 1962.

Bradley, S. A. J. Anglo-Saxon Poetry. London; Rutland, VT: Dent ; C.E. Tuttle, 1995.

Briggs, Charles F. "Scholarly and Intellectual Authority in Late Medieval European Mirrors." In Global Medieval: Mirrors for Princes Reconsidered, edited by Regula Forster and Neguin Yavari, 26-41. Ilex Foundation Series 15. Boston, Massachusetts: Ilex Foundation, 2015.

Brown, George Hardin. "Bede's Neglected Commentary on Samuel." In Innovation and Tradition in the Writings of the Venerable Bede, edited by Scott DeGregorio, 12142. Morgantown: West Virginia University Press, 2006.

. "Bede's Style in His Commentary On I Samuel." In Text, Image, Interpretation: Studies in Anglo-Saxon Literature and Its Insular Context in Honour of Éamonn Ó Carragáin, edited by Alastair Minnis and Jane Roberts, 233-51. Studies in the Early Middle Ages 18. Turnhout, Belgium: Brepols, 2007.

. A Companion to Bede. Anglo-Saxon Studies 12. Woodbridge; Rochester, NY: Boydell Press, 2009.

Brown, Michelle P. "Bede's Life in Context." In The Cambridge Companion to Bede, edited by Scott DeGregorio, 3-24. Cambridge Companions to Literature. Cambridge; New York: Cambridge University Press, 2010. 
Bullough, Donald A. "What Has Ingeld to Do with Lindisfarne?" Anglo-Saxon England 22 (1993): 93-125.

Burckhardt, Jacob. The Age of Constantine the Great. Translated by Moses Hadas. New York: Pantheon, 1949.

Cam, Helen M. Local Government in Francia and England: A Comparison of the Local Administration and Jurisdiction of the Carolingian Empire with that of the West Saxon Kingdom. London: Hodder \& Stoughton, 1912.

Campbell, Alistair, ed. Encomium Emmae Reginae. Cambridge University Press, 1998.

Campbell, James. The Anglo-Saxon State. London; New York: Hambledon and London, 2000.

. "Asser's Life of Alfred." In The Inheritance of Historiography, 350-900, edited by Christopher Holdsworth and T.P. Wiseman, 115-35. Exeter: University of Exeter Press, 1986.

. "Bede's Reges and Principes." In Essays in Anglo-Saxon History, 85-98. London; Ronceverte, WV, U.S.A.: Hambledon Press, 1986.

. "Secular and Political Contexts." In The Cambridge Companion to Bede, edited by Scott DeGregorio, 25-39. Cambridge Companions to Literature. Cambridge; New York: Cambridge University Press, 2010.

Carella, Bryan. "Asser's Bible and the Prologue to the Laws of Alfred." Anglia 130, no. 2 (2012): 195-206.

Chaney, William A. The Cult of Kingship in Anglo-Saxon England: The Transition from Paganism to Christianity. Berkeley: University of California Press, 1970.

Chenard, Marianne Malo. "King Oswald's Holy Hands: Metonymy and the Making of a Saint in Bede's Ecclesiastical History." Exemplaria 17, no. 1 (2005): 33-56.

Clayton, Mary. “Ælfric and Æthelred.” In Essays on Anglo-Saxon and Related Themes in Memory of Lynne Grundy, edited by Jane Roberts and Janet Nelson, 65-88. Medieval Studies 17. London: King's College London, Centre for Late Antique and Medieval Studies, 2000.

. "De Duodecim Abusiuis, Lordship and Kingship in Anglo-Saxon England." In 
Saints and Scholars: New Perspectives on Anglo-Saxon Literature and Culture in Honour of Hugh Magennis, edited by Stuart McWilliams, 141-63. Cambridge: D.S. Brewer, 2012.

, ed. Two AElfric Texts: The Twelve Abuses and The Vices and Virtues. AngloSaxon Texts 11. Suffolk, UK: D.S. Brewer, 2013.

Colgrave, Bertram, and R.A.B. Mynors, eds. Bede's Ecclesiastical History of the English People. Oxford: Clarendon P., 1969.

Councils and Synods: A.D. 871-1204. Vol. 1. 2 vols. Oxford: Clarendon Press, 1981.

Cranz, F. Edward. "Kingdom and Polity in Eusebius of Caesarea." The Harvard Theological Review 45, no. 1 (1952): 47-66.

Cubitt, Catherine. "Councils, Church." In The Wiley Blackwell Encyclopedia of AngloSaxon England, edited by Michael Lapidge, John Blair, Simon Keynes, and Donald Scragg, 127-8. Second Edition. Oxford; Malden, Mass.: John Wiley \& Sons, 2014.

. "The Politics of Remorse: Penance and Royal Piety in the Reign of Æthelred the Unready." Historical Research 85, no. 228 (May 2012): 179-92.

. "Sites and Sanctity: Revisiting the Cult of Murdered and Martyred AngloSaxon Royal Saints." Early Medieval Europe 9, no. 1 (March 2000): 53-83.

Damon, John Edward. "Advisors for Peace in the Reign of Æthelred Unræd." In Peace and Negotiation: Strategies for Coexistence in the Middle Ages and the Renaissance, edited by Diane Wolfthal, 57-78. Studies in the Middle Ages and the Renaissance 4. Turnhout: Brepols, 2000.

. "Sanctifying Anglo-Saxon Ealdormen: Lay Sainthood and the Rise of the Crusading Ideal." In Via Crucis: Essays on Early Medieval Sources and Ideas in Memory of J.E. Cross, edited by Thomas N. Hall, Thomas D. Hill, and Charles D. Wright, 185-209. Medieval European Studies 1. Morgantown, WV: West Virginia University Press, 2002.

. Soldier Saints and Holy Warriors: Warfare and Sanctity in the Literature of Early England. Hampshire, Eng.; Burlington, VT: Ashgate, 2003.

Davis-Secord, Jonathan. “Rhetoric and Politics in Archbishop Wulfstan's Old English 
Homilies." Anglia 126, no. 1 (2008): 65-96.

Dobbie, Elliott Van Kirk, ed. The Battle of Maldon. In The Anglo-Saxon Minor Poems, 716. Anglo-Saxon Poetic Records 6. New York: Columbia University Press, 1942.

Douay-Rheims Bible Online. DRBO.org, 2016. http://www.drbo.org. [Richard Challoner, Holy Bible. Douay-Rheims Version. John Murphy Company, 1899; Biblia Sacra Vulgata. Clementine version.].

Drake, Harold. In Praise of Constantine: A Historical Study and New Translation of Eusebius' Tricennial Orations. University of California Publications: Classical Studies 15. Berkeley: University of California Press, 1976.

Einhard. Vita Karoli Magni: The Life of Charlemagne. Edited by Evelyn Scherabon Firchow and Edwin H. Zeydel. Coral Gables, Fla: University of Miami Press, 1972.

Erdmann, Carl. The Origin of the Idea of Crusade. Translated by Marshall Withed Baldwin and Walter A. Goffart. Ann Arbor: University of Michigan, University Library, 2010.

Escobedo, Libby Karlinger. The Milemete Treatise and Companion Secretum Secretorum: Iconography, Audience, and Patronage in Fourteenth-Century England. Lewiston, N.Y: Edwin Mellen Press, 2011.

Eusebius. "Oration in Praise of Constantine." In Nicene and Post-Nicene Fathers, edited by Philip Schaff and Henry Wace, translated by Ernest Cushing Richardson, Vol. 1. Second Series. Buffalo, NY: Christian Literature Publishing Co., 1890. http://www.newadvent.org/fathers/2504.htm. [Revised and edited for New Advent by Kevin Knight, 2009.]

Ferster, Judith. Fictions of Advice: the Literature and Politics of Counsel in Late Medieval England. Philadelphia: University of Pennsylvania Press, 1996.

Firchow, Evelyn Scherabon and Edwin H. Zeydel. Introduction to Vita Karoli Magni: The Life of Charlemagne, by Einhard. Edited by Evelyn Scherabon Firchow and Edwin H. Zeydel. Coral Gables, Fla: University of Miami Press, 1972.

Forster, Regula, and Neguin Yavari. Introduction to Global Medieval: Mirrors for Princes Reconsidered, edited by Regula Forster and Neguin Yavari, 1-10. Ilex Foundation Series 15. Boston, Massachusetts: Ilex Foundation, 2015. 
Foley, W. Trent, and Nicholas J. Higham. "Bede on the Britons." Early Medieval Europe 17, no. 2 (May 2009): 154-85.

Forsythe, Gary. A Critical History of Early Rome: From Prehistory to the First Punic War. Berkeley: University of California Press, 2005.

Fowler, Roger. "Some Stylistic Features of the Sermo Lupi." Journal of English and Germanic Philology 65 (1966): 1-18.

Fox, Peter. An Introduction to Anglo-Saxon Kingship. Hockwold-cum-Wilton: AngloSaxon Books, 2004.

Frank, Roberta. "The Ideal of Men Dying with Their Lord in The Battle of Maldon: Anachronism or nouvelle Vague." In People and Places in Northern Europe, 5001600: Essays in Honour of Peter Hayes Sawyer, edited by I. N. Wood and Niels Lund. Woodbridge: Boydell Press, 1991.

Garmonsway, George Norman. trans. and ed. The Anglo-Saxon Chroncile. London: J.M. Dent \& Sons Ltd, 1990.

Gatch, Milton McC. Preaching and Theology in Anglo-Saxon England: Alfric and Wulfstan. Toronto, 1977. . Traditions and Loyalties: Man and His World in Old English Literature. New York, 1971.

Giancarlo, Matthew. "Mirror, Mirror: Princely Hermeneutics, Practical Constitutionalism, and the Genres of the English Fürstenspiegel." Exemplaria 27, no. 1-2 (May 1, 2015): 35-54.

Gignac, Joseph. “Anathema.” The Catholic Encyclopedia. New York: Robert Appleton Company, 1907. http://www.newadvent.org/cathen/01455e.htm. [Revised and edited for New Advent by Kevin Knight, 2012]

Gildas. Gildae de Excidio Britanniae, Fragmenta, Liber de Paenitentia, Accedit et Lorica Gildae: The Ruin of Britain, Fragments from Lost Letters, The Penitential, Together with The Lorica of Gildas. Edited by Hugh Williams. London: Published for the Honourable Society of Cymmrodorion by D. Nutt, 1899.

. The Ruin of Britain, and Other Works. Edited and translated by Michael Winterbottom. History from the Sources 7. London: Rowman and Littlefield, 
1978.

Given-Wilson, Chris. The Royal Household and the King's Affinity: Service, Politics, and Finance in England, 1360-1413. New Haven: Yale University Press, 1986.

Gneuss, Helmut, and Michael Lapidge. Anglo-Saxon Manuscripts: A Bibliographical Handlist of Manuscripts and Manuscript Fragments Written or Owned in England up to 1100. Toronto Anglo-Saxon Series 15. Toronto: University of Toronto Press, 2014.

Godden, Malcolm, ed. Alfric's Catholic Homilies: Introduction, Commentary and Glossary. EETS S.S. 18. Oxford and New York: Oxford University Press, 2000. . "Biblical Literature: The Old Testament." In The Cambridge Companion to Old English Literature, edited by Malcolm Godden and Michael Lapidge, 214-33. Second Edition. Cambridge: Cambridge UP, 2013.

. “Did King Alfred Write Anything?” Medium Aevum 76, no. 1 (June 2007): 123.

. "King and Counselor in the Alfredian Boethius." In Intertexts: Studies in Anglo-Saxon Culture Presented to Paul E. Szarmach, edited by Virginia Blanton and Helene Scheck, 191-207. Medieval and Renaissance Texts and Studies, 334. Tempe, Ariz.: Arizona Center for Medieval and Renaissance Studies, 2008.

. "The Relations of Wulfstan and Ælfric: A Reassessment." In Archbishop of York: The Proceedings of the Second Alcuin Conference, edited by Matthew Townend, 353-74. Studies in the Early Middle Ages 10. Turnhout: Brepols, 2004.

Goffart, Walter A. The Narrators of Barbarian History (A.D. 550-800) Jordanes, Gregory of Tours, Bede, and Paul the Deacon. Notre Dame, Indiana: Univ. of Notre Dame Press, 1988.

Green, D. H. The Carolingian Lord; Semantic Studies on Four Old High German Words: Balder, Frô, Truhtin, Hêrro. Cambridge: University Press, 1965.

Green, Judith. "Kingship, Lordship, and Community in Eleventh-Century England." Anglo-Norman Studies 31 (2009): 1-16.

Grigg, Julianna. "The Just King and De Duodecim Abusiuis Saeculi." Parergon: Bulletin of the Australian and New Zealand Association for Medieval and Renaissance 
Studies 27, no. 1 (2010): 27-51.

Halsall, Paul, ed. "Saints' Lives." In Internet Medieval Sourcebook. Fordham University Center for Medieval Studies, 1996. Accessed July 1, 2017. http://sourcebooks.fordham.edu/Halsall/sbook3.asp.

, ed. "Urban II: Speech at Council of Clermont, 1095, according to Fulcher of Chartres." In Internet Medieval Sourcebook. Fordham University Center for Medieval Studies, 1997. https://sourcebooks.fordham.edu/source/urban25vers.html.

Hamer, Richard, ed. and trans. The Battle of Maldon. In A Choice of Anglo-Saxon Verse, 48-69. London: Faber \& Faber, 1970.

Hare, Kent G. "Christian Heroism and Holy War in Anglo-Saxon England." Dissertation, Louisiana State University and Agricultural \& Mechanical College, 1997.

. "Heroes, Saints, and Martyrs: Holy Kingship from Bede to Ælfric." Heroic Age 9 (October 2006). Accessed July 1, 2017. http://www.heroicage.org/issues/9/hare.html.

Harris, Stephen J. "Oaths in The Battle of Maldon." In The Hero Recovered: Essays on Medieval Heroism in Honor of George Clark, edited by Robin Waugh and James Weldon. Kalamazoo: Medieval Institute Publications, Western Michigan University, 2010.

. Race and Ethnicity in Anglo-Saxon Literature. New York: Routledge, 2003.

Head, Thomas. "Hagiography.” Hagiography Society. Accessed June 30, 2017. http://www.hagiographysociety.org/wpcontent/uploads/2013/03/Head_Hagiography.pdf.

Herbermann, Charles G., Edward A. Pace, Conde B. Pallen, Thomas J. Shahan, and John J. Wynne, eds. "St. Dunstan." In The Catholic Encyclopedia: An International Work of Reference on the Constitution, Doctrine, Discipline, and History of the Catholic Church, 5:199-202. New York: Robert Appleton Company, 1909.

Henry of Huntingdon. The History of the English People 1000-1154. Translated by Diana Greenway. Reissue edition. Oxford: Oxford University Press, 2009.

Higham, N. J. "Bede's Agenda in Book IV of the 'Ecclesiastical History of the English 
People': A Tricky Matter of Advising the King." Journal of Ecclesiastical History 64, no. 3 (July 2013): 476-93.

. The Convert Kings: Power and Religious Affiliation in Early Anglo-Saxon

England. Manchester, UK ; New York: Manchester University Press : St. Martin's Press, 1997.

. The Death of Anglo-Saxon England. Stroud: Sutton Pub., 2000.

. The English Conquest: Gildas and Britain in the Fifth Century. Manchester: Manchester University Press, 1994.

. The Kingdom of Northumbria: AD 350-1100. Dover, NH: A. Sutton, 1993.

. (Re-)Reading Bede: The Ecclesiastical History in Context. London: Routledge, 2006.

Hill, Joyce. “Authorial Adaptation: Ælfric, Wulfstan and the Pastoral Letters.” In Text and Language in Medieval English Prose: A Festschrift for Tadao Kubouchi, edited by Akio Oizumi, Jacek Fisiak, and John Scahill, 63-75. Studies in English Medieval Language and Literature 12. Frankfurt am Main: Peter Lang, 2005.

Hill, Thomas D. "The Christian Language and Theme of Beowulf." In Beowulf: A Verse Translation, Norton Critical Edition., 197-211. New York: Norton, 2002.

. “Non Nisi Uirgam Tantum... in Manu': Sigeberht's Mosaic Aspirations (Bede, Historia Ecclesiastica III, 18)." Notes and Queries 53, no. 4 (December 2006): $391-95$.

. "A Riddle on the Three Orders in the Collectanea Pseudo-Bedae?," Philological Quarterly 80.3 (Summer 2001): 205-12.

. "The virga of Moses and the Old English Exodus." In Old English Literature in Context: Ten Essays, edited by John D. Niles, 57-65. Cambridge: D. S. Brewer; Rowman \& Littlefield, 1980.

Hindley, Geoffrey. A Brief History of the Anglo-Saxons. New York: Carroll \& Graf Publishers, 2006.

Hollerich, Michael J. Eusebius of Caesarea's Commentary on Isaiah. Oxford: Clarendon, 1999. 
. "Religion and Politics in the Writings of Eusebius: Reassessing the First 'Court Theologian,"' Church History 59 (1990): 309-25.

Hollis, Stephanie. "The Thematic Structure of the Sermo Lupi." Anglo-Saxon England 6 (1977): 175-95.

Hough, Carole. "Naming and Royal Authority in Anglo-Saxon Law." In Kingship, Legislation and Power in Anglo-Saxon England., edited by Gale R. OwenCrocker and Brian W Schneider, 201-17. Publications of the Manchester Centre for Anglo-Saxon Studies, 13. Woodbridge, Suffolk: Boydell Press, 2013.

Howatson, M. C, and Ian Chilvers, eds. "Eusebius." In The Concise Oxford Companion to Classical Literature. Oxford University Press, 2011. www.oxfordreference.com.

Howe, Nicholas. Migration and Mythmaking in Anglo-Saxon England. Notre Dame: University of Notre Dame Press, 2001.

Hurlock, Kathryn. Britain, Ireland and the Crusades, c. 1000-1300. New York: Palgrave Macmillan, 2013.

Insley, Charles. "Kings and Lords in Tenth-Century Cornwall." History 98, no. 329 (January 2013): 2-22.

Irvine, Susan. The Anglo-Saxon Chronicle: A Collaborative Edition. Vol. 7 MS. E. Cambridge: D.S. Brewer, 2004.

Jardine, Lisa, ed. The Education of a Christian Prince. Translated by Neil M. Cheshire and Michael J. Heath. Cambridge Texts in the History of Political Thought. Cambridge, U.K.: Cambridge University Press, 1997.

Johnson, Aaron P. Ethnicity and Argument in Eusebius' Praeparatio Evangelica. Oxford: Oxford University Press, 2006.

Jones, Putnam Fennell. A Concordance to the Historia Ecclesiastica of Bede. Publication (Mediaeval Academy of America) 2. Cambridge, Mass: Pub. for the Concordance Society by The Mediaeval Academy of America, 1929.

Jurovics, Raachel. "Sermo Lupi and the Moral Purpose of Rhetoric." In The Old English Homily and Its Backgrounds, edited by Paul E Szarmach and Bernard F. Huppé, 203-20. Albany: University of New York, 1978. 
Kantorowicz, Ernst Hartwig. The King's Two Bodies; a Study in Mediaeval Political Theology. Princeton, N.J.: Princeton University Press, 1957.

Karkov, Catherine E. "The Mother's Tongue and the Father's Prose." Parallax 18, no. 3 (2012): 27-37.

Kershaw, Paul. "Illness, Power and Prayer in Asser's Life of King Alfred." Early Medieval Europe 10, no. 2 (July 2001): 201-24.

Keynes, Simon. "An Abbot, an Archbishop, and the Viking Raids of 1006-7 and 100912." Anglo-Saxon England 36, no. 1 (January 2007): 151-226.

. "Church Councils, Royal Assemblies, and Anglo-Saxon Royal Diplomas." In Kingship, Legislation and Power in Anglo-Saxon England, edited by Gale R. Owen-Crocker and Brian W Schneider, 17-182. Publications of the Manchester Centre for Anglo-Saxon Studies 13. Woodbridge, Suffolk, UK; Rochester, NY: The Boydell Press, 2013.

. The Diplomas of King Ethelred "The Unready" (978-1016): A Study in Their Use as Historical Evidence. Cambridge Studies in Medieval Life and Thought, 3rd. ser., 13. Cambridge: Cambridge University Press, 1980.

. "King Alfred and the Mercians." In Kings, Currency, and Alliances: History and Coinage of Southern England in the Ninth Century, edited by Mark A. S. Blackburn and David N. Dumville, 1-45. Woodbridge, Suffolk: The Boydell Press, 1998.

, and Michael Lapidge, eds. Alfred the Great: Asser's Life of King Alfred and Other Contemporary Sources. Harmondsworth, Eng; New York: Penguin Books, 1983.

Kirby, D.P. "Bede's Native Sources for the Historia Ecclesiastica." Bulletin of the John Rylands Library 48 (66 1965): 341-71. . The Earliest English Kings. Revised. London and New York: Routledge, 2000.

. "King Ceolwulf of Northumbria and the Historia Ecclesiastica." Studia Celtica 14-15 (1980): 168-73.

Klaeber, Frederick. Klaeber's Beowulf and the Fight at Finnsburg. Edited by R. D. Fulk, Robert E. Bjork, and John D. Niles. Toronto; Buffalo: University of Toronto 
Press, 2008.

Klein, R.W. "Samuel, Books of." In The International Standard Bible Encyclopedia, edited by Geoffrey W. Bromiley, 4:312-20. Grand Rapids, Mich.: Wm. B. Eerdmans Publishing, 1995.

Korrel, Peter. An Arthurian Triangle: A Study of the Origin, Development, and Characterization of Arthur, Guinevere, and Modred. Leiden: E.J. Brill, 1984.

Laistner, M.L.W. "The Library of the Venerable Bede." In Bede: His Life, Times, and Writings: Essays in Commemoration of the Twelfth Centenary of His Death, edited by A. Hamilton Thompson, 237-66. New York: Russell \& Russell, 1966.

Lane, Robert. Shepheard's Devises: Edmund Spenser's "Shepheardes Calender" and the Institutions of Elizabethan Society. Athens: University of Georgia Press, 1993.

Lapidge, Michael. The Anglo-Saxon Library. Oxford; New York: Oxford University Press, 2006.

. "Dunstan." In The Wiley Blackwell Encyclopedia of Anglo-Saxon England, edited by Michael Lapidge, John Blair, Simon Keynes, and Donald Scragg, 15051. Second Edition. Oxford; Malden, Mass.: John Wiley \& Sons, 2014.

. "John the Old Saxon (fl. c.885-904)." In Oxford Dictionary of National Biography. Oxford University Press, 2004. Accessed January 11, 2017. http://www.oxforddnb.com/view/article/52277.

, and D. N. Dumville, eds. Gildas: New Approaches. Studies in Celtic History 5. Woodbridge, Suffolk; Dover, N.H: Boydell Press, 1984.

Lavelle, Ryan. "Ine 70.1 and Royal Provision in Anglo-Saxon Wessex." In Kingship, Legislation and Power in Anglo-Saxon England., edited by Gale Owen-Crocker and Brian W Schneider, 259-73. Publications of the Manchester Centre for Anglo-Saxon Studies, 13. Woodbridge, Suffolk: Boydell Press, 2013.

Lehmberg, S.E., ed. The Book Named The Governor. London: Dent, 1962.

Lionarons, Joyce Tally. The Homiletic Writings of Archbishop Wulfstan: A Critical Study. Anglo-Saxon Texts 14. Woodbridge: D.S. Brewer, 2010.

. "Textual Identity, Homiletic Reception, and Wulfstan's 'Sermo Ad Populum.” 
The Review of English Studies 55, no. 219 (2004): 157-82.

Loyn, H. R. The Governance of Anglo-Saxon England, 500-1087. Stanford, Calif.: Stanford University Press, 1984.

Machiavelli, Niccolò. The Prince. Translated by William K Marriott. J.M. Dent \& Sons: London; E.P. Dutton \& Co.: New York, 1958.

McIlwain, Charles Howard. The Political Works of James I. Whitefish: Kessinger Publishing, 2010.

Maddicott, John Robert. The Origins of the English Parliament, 924-1327. Oxford: Oxford University Press, 2010.

Magennis, Hugh, and Mary Swan. A Companion to AElfric. Leiden; Boston: Brill, 2009.

Marsden, John. Northanhymbre Saga: The History of the Anglo-Saxon Kings of Northumbria. London: Kyle Cathie, 1992.

McClure, Judith. "Bede's Old Testament Kings." In Ideal and Reality in Frankish and Anglo-Saxon Society: Studies Presented to J.M. Wallace-Hadrill, edited by Patrick Wormald. Oxford, England: B. Blackwell, 1983.

McKane, William, ed. I \& II Samuel. Torch Bible Commentaries. London: SCM Press Ltd., 1963.

Meaney, Audrey. “King Alfred and His Secretariat.” Parergon 11 (1975): 16-24.

Mercken, H. Paul F., ed. The Greek Commentaries on the Nicomachean Ethics of Aristotle in the Latin Translation of Robert Grosseteste, Bishop of Lincoln. Leuven, Belgium: Leuven University Press, 1991.

Meyers, Henry. Medieval Kingship. Chicago: Nelson-Hall, 1982.

Miller, M. "Bede's Use of Gildas." The English Historical Review 90, no. 355 (1975): $241-61$.

Momigliano, Arnaldo, and Tim Cornell. "Cliens." In The Oxford Classical Dictionary, edited by Simon Hornblower, Antony Spawforth, and Esther Eidinow, Fourth Edition, 334. Oxford: Oxford University Press, 2012. 
Nelson, Janet L. "The Franks and the English in the Ninth Century Reconsidered." In The Preservation and Transmission of Anglo-Saxon Culture, edited by Paul E.

Szarmach and Joel T. Rosenthal. Kalamazoo, MI: Medieval Institute Publications, Western Michigan University, 1997.

. "Waiting for Alfred." Early Medieval Europe 7 (1998): 115-24.

North, John. "Pontifex / Pontifices." In The Oxford Classical Dictionary, edited by Simon Hornblower, Antony Spawforth, and Esther Eidinow, Fourth edition, 1183. Oxford: Oxford University Press, 2012.

Oakley, Francis. Kingship: The Politics of Enchantment. Malden, MA; Oxford: Blackwell Pub., 2006.

O’Brien, Conor. Bede's Temple: An Image and Its Interpretation. Oxford: Oxford University Press, 2015.

O'Brien O'Keeffe, Katherine. "Values and Ethics in Heroic Literature." In The Cambridge Companion to Old English Literature, edited by Michael Lapidge and Malcolm Godden, 101-19. Second Edition. Cambridge [England]; New York: Cambridge University Press, 2013.

O'Donovan, Oliver, and Joan Lockwood O'Donovan, eds. From Irenaeus to Grotius: A Sourcebook in Christian Political Thought, 100-1625. Grand Rapids, Mich.: William B. Eerdmans Pub., 1999.

Orchard, Andy. "Crying Wolf: Oral Style and the Sermones Lupi." Anglo-Saxon England 21 (1992): 239-64.

. "Wulfstan the Homilist." In The Wiley Blackwell Encyclopedia of Anglo-Saxon England, edited by Michael Lapidge, John Blair, Simon Keynes, and Donald Scragg, 514-15. Second Edition. Oxford; Malden, Mass.: John Wiley \& Sons, 2014.

. "Wulfstan as Reader, Writer, and Rewriter." In The Old English Homily: Precedent, Practice, and Appropriation, edited by Aaron J. Kleist, 157-82. Studies in the Early Middle Ages 17. Turnhout: Brepols, 2007.

Orr, James, John Nuelsen, Edgar Mullins, Morris Evans, and Melvin Grove Kyle, eds. “King, Kingdom.” In International Bible Encyclopedia Online, n.p., 2017. [1939] 
Paterno, Salvatore. The Liturgical Context of Early European Drama. Potomac: Scripta Humanistica, 1989.

Plummer, Carolus. Venerabilis Baedae Opera Historica: Historiam Ecclesiasticam Gentis Anglorum; Historiam Abbatum; Epistolam Ad Ecgberctum Una Cum Historia Abbatum Auctore Anonymo. 2 vols. Oxonii: Oxford University Press, 1956.

Pons-Sanz, Sara M. "For-Gode-and-for-Worolde: Wulfstan's Differentiation of the Divine and Worldly Realms through Word-Formation Processes." English Studies 85, no. 4 (August 2004): 281-96.

Pratt, David. "The Illnesses of King Alfred the Great." Anglo-Saxon England 30, no. 1 (January 2001): 39.

Rabin, Andrew, ed. The Political Writings of Archbishop Wulfstan of York. Manchester Medieval Sources Series. Manchester: Manchester University Press, 2015.

. "Witnessing Kingship: Royal Power and the Legal Subject in the Old English Laws." In Kingship, Legislation and Power in Anglo-Saxon England, edited by Gale Owen-Crocker and Brian W Schneider, 219-36. Publications of the Manchester Centre for Anglo-Saxon Studies, 13. Woodbridge, Suffolk: Boydell Press, 2013.

Reno, Frank D. The Historic King Arthur: Authenticating the Celtic Hero of Post-Roman Britain. McFarland, 1996.

Riley-Smith, Jonathan. The First Crusade and the Idea of Crusading. London; New York: Continuum International Publishing Group, 2012.

Roach, Levi. Athelred the Unready. New Haven; London: Yale University Press, 2016.

. Kingship and Consent in Anglo-Saxon England, 871-978: Assemblies and the State in the Early Middle Ages. Cambridge; New York: Cambridge University Press, 2013.

Roberts, Alexander, trans. Sulpitius Severus on the Life of St. Martin. In A Select Library of Nicene and Post-Nicene Fathers of the Christian Church, Vol. 11. Second Series. New York, 1894. http://www.users.csbsju.edu/ eknuth/npnf211/sulpitiu/lifeofst.html\#4. 
Rowley, Sharon M. "Bede in Later Anglo-Saxon England." In The Cambridge Companion to Bede, edited by Scott DeGregorio, 216-28. Cambridge Companions to Literature. Cambridge; New York: Cambridge University Press, 2010.

Sawyer, P. H, and I. N Wood. Early Medieval Kingship. Leeds: University of Leeds, 1979.

Scanlon, Larry. Narrative, Authority, and Power: The Medieval Exemplum and the Chaucerian Tradition. Cambridge Studies in Medieval Literature 20. New York: Cambridge University Press, 1994.

Scharer, Anton. "The Writing of History at King Alfred's Court." Early Medieval Europe 5, no. 2 (January 1, 1996): 177-206.

Scheil, Andrew P. The Footsteps of Israel: Understanding Jews in Anglo-Saxon England. Ann Arbor [Mich.]: University of Michigan Press, 2004.

Schmitz, Leonhard. "Pontifex." In A Dictionary of Greek and Roman Antiquities, edited by William Smith, 939-42. John Murray, London, 1875.

Scott, James C. Domination and the Arts of Resistance: Hidden Transcripts. Revised edition. New Haven: Yale University Press, 1992.

Scragg, Donald., ed. The Battle of Maldon.. Old and Middle English Texts. Manchester: Manchester University Press, 1981.

, ed. The Battle of Maldon: A.D. 991. Manchester: Manchester University Press, 1991.

. "Comitatus." In The Wiley Blackwell Encyclopedia of Anglo-Saxon England, edited by Michael Lapidge, John Blair, Simon Keynes, and Donald Scragg, 121. Second Edition. Oxford; Malden, Mass.: John Wiley \& Sons, 2014.

. Introduction to The Battle of Maldon, 1-56. Old and Middle English Texts. Manchester: Manchester University Press, 1981.

. The Return of the Vikings: The Battle of Maldon 991. Stroud: Tempus, 2006.

Sheppard, Alice. Families of the King: Writing Identity in the Anglo-Saxon Chronicle. Toronto; Buffalo: University of Toronto Press, 2004. 
. "The King's Family: Securing the Kingdom in Asser's Vita Alfredi."

Philological Quarterly 80, no. 4 (2001): 409-39.

. "Noble Counsel, No Counsel: Advising Ethelred the Unready." In Via Crucis:

Essays on Early Medieval Sources and Ideas in Memory of J.E. Cross, edited by Thomas N. Hall, Thomas D. Hill, and Charles D. Wright, 393-422. Medieval European Studies 1. Morgantown, WV: West Virginia University Press, 2002.

Singh, Devin. "Eusebius as Political Theologian: The Legend Continues." Harvard Theological Review 108, no. 1 (January 2015): 129-54.

Sisam, Kenneth. "Anglo-Saxon Royal Genealogies." Proceedings of the British Academy 39 (1954): 287-348.

Skeat, Walter W., ed. Aelfric's Lives of Saints: Being a Set of Sermons on Saints'Days Formerly Observed by the English Church. Vol. 2. London: Published for the Early English Text Society by Kegan Paul, Trench, Trübner \& Co, 1900.

Smyth, Alfred P., ed. The Medieval Life of King Alfred the Great: A Translation and Commentary on the Text Attributed to Asser. New York: Palgrave, 2002.

Stafford, Pauline. "Kings, Kingships, and Kingdoms." In From the Vikings to the Normans, edited by Wendy Davies, 11-71. The Short Oxford History of the British Isles. Oxford and New York: Oxford University Press, 2003.

. Queen Emma and Queen Edith: Queenship and Women's Power in EleventhCentury England. Oxford: Blackwell Publishers, 2004.

Stenton, F. M. Anglo-Saxon England. Oxford: Clarendon Press, 1971.

Stevenson, William Henry, and Dorothy Whitelock, eds. Asser's Life of King Alfred: Together with the Annals of Saint Neots Erroneously Ascribed to Asser. Oxford: Clarendon Press, 1959.

Stuttgarter Psalter. Württembergische Landesbibliothek. Accessed February 24, 2017. http://digital.wlbstuttgart.de/sammlungen/sammlungsliste/werksansicht/?no_cache=1\&tx_dlf $\% 5 \mathrm{Bi}$ $\mathrm{d} \% 5 \mathrm{D}=1343 \& \mathrm{tx} \_\mathrm{dlf} \% 5 \mathrm{Bpage} \% 5 \mathrm{D}=1$.

Stringer, Daniel. "The Political Theology of Eusebius Pamphili, Bishop of Caesarea." Patristic and Byzantine Review 1 (1982): 137-51. 
Tacitus, Cornelius. Germania. Edited by J. B. Rives. Clarendon Ancient History Series. Oxford: Oxford University Press, 1999.

Thacker, Alan. "Bede and History." In The Cambridge Companion to Bede, edited by Scott DeGregorio, 170-89. Cambridge Companions to Literature. Cambridge ; New York: Cambridge University Press, 2010.

Townend, Matthew, ed. Archbishop of York: The Proceedings of the Second Alcuin Conference. Studies in the Early Middle Ages 10. Turnhout: Brepols, 2004.

Treharne, Elaine M. "The Battle of Maldon." In Old and Middle English c.890-c. 1400: An Anthology. Malden, MA: Blackwell Pub., 2004.

. "Wulfstan's Sermo Lupi Ad Anglos." In Old and Middle English c.890-c.1400: An Anthology, 226-33. Malden, MA: Blackwell Pub., 2004.

Trousdale, Alaric A. "Being Everywhere at Once: Delegation and Royal Authority in Late Anglo-Saxon England." In Kingship, Legislation and Power in Anglo-Saxon England, edited by Gale Owen-Crocker and Brian W Schneider, 276-96. Publications of the Manchester Centre for Anglo-Saxon Studies, 13. Woodbridge, Suffolk: Boydell Press, 2013.

Updegraff, Derek. "Style and Structure, Politics, and Preaching: The Lives of Saints and Other Alliterative Works by Ælfric of Eynsham." Diss., University of MissouriColumbia, 2013.

Wallace-Hadrill, D. S. Eusebius of Caesarea. London: A.R. Mowbray, 1960.

Wallace-Hadrill, J. M. Bede's Ecclesiastical History of the English People: A Historical Commentary. Oxford Medieval Texts. Oxford: Oxford University Press, 1988.

. Early Germanic Kingship in England and on the Continent: The Ford Lectures Delivered in the University of Oxford in Hilary Term 1970. Oxford: Clarendon Press, 1971.

Wenzel, Siegfried. "Reflections on (New) Philology” Speculum 65, no. 1 (1990): 11-18.

Westgard, Joshua A. "Bede and the Continent in the Carolingian Age and Beyond." In The Cambridge Companion to Bede, edited by Scott DeGregorio, 201-15. Cambridge Companions to Literature. Cambridge ; New York: Cambridge University Press, 2010. 
Whitelock, Dorothy. The Genuine Asser. Stenton Lecture 1967. Reading: University of Reading, 1968.

Whitelock, Dorothy. Sermo Lupi Ad Anglos. Exeter: University of Exeter, 1980.

Wilcox, Jonathan. "Wulfstan's Sermo Lupi Ad Anglos as Political Performance: 16 February 1014 and Beyond." In Archbishop of York: The Proceedings of the Second Alcuin Conference, edited by Matthew Townend, 375-96. Studies in the Early Middle Ages 10. Turnhout: Brepols, 2004.

Williams, Ann. Kingship and Government in Pre-Conquest England, c.500-1066. New York; Houndmills, Hampshire: St. Martin's Press ; Macmillan, 1999. . Introduction to Kingship, Legislation and Power in Anglo-Saxon England, edited by Gale Owen-Crocker and Brian W Schneider, 1-14. Publications of the Manchester Centre for Anglo-Saxon Studies 13. Woodbridge, Suffolk, UK; Rochester, NY: The Boydell Press, 2013.

. "Regional Communities and Royal Authority in the Late Old English Kingdom: The Crisis of 1051-1052 Revisited." History 98, no. 329 (January 2013): 23-40.

Williams, George H. "Christology and Church-State Relations in the Fourth Century." Church History 20, no. 3 (1951): 3-33.

Wise, John, and W. Mackreth Noble. Ramsey Abbey: Its Rise and Fall. Huntingdon: Ellis \& Cooper, 1882.

Woolf, Rosemary. "The Ideal of Men Dying with Their Lord in the Germania and in The Battle of Maldon." Anglo-Saxon England 5 (1976): 63-81.

Wormald, Patrick. "Archbishop Wulfstan: Eleventh-Century State Builder." In Archbishop of York: The Proceedings of the Second Alcuin Conference, edited by Matthew Townend, 10-27. Studies in the Early Middle Ages 10. Turnhout: Brepols, 2004.

. "Living with King Alfred." Haskins Society Journal: Studies in Medieval History 15 (2006): 1-39.

. The Making of English Law: King Alfred to the Twelfth Century. Oxford: Blackwell Publishers, 1999. 
Wright, J. Robert. A Companion to Bede: A Reader's Commentary on The Ecclesiastical History of the English People. Grand Rapids, Mich.: William B. Eerdmans Pub., 2008.

Wright, Neil. "Gildas's Prose Style and Its Origins." In Gildas: New Approaches, edited by Michael Lapidge and D. N. Dumville, 107-28. Studies in Celtic History 5. Woodbridge, Suffolk; Dover, N.H: Boydell Press, 1984.

Yorke, Barbara. "The Burial of Kings in Anglo-Saxon England." In Kingship, Legislation and Power in Anglo-Saxon England, edited by Gale Owen-Crocker and Brian W Schneider, 237-57. Publications of the Manchester Centre for Anglo-Saxon Studies, 13. Woodbridge, Suffolk: Boydell Press, 2013.

. Kings and Kingdoms of Early Anglo-Saxon England. London ; New York: Routledge, 1990.

. "Kings and Kingship." In A Companion to the Early Middle Ages: Britain and Ireland, C. 500 - C. 1100, edited by Pauline Stafford, 76-90. Blackwell Companions to British History. Chichester, UK and Malden, MA: Blackwell, 2009. 
Toby R. Beeny was born in Troy, Missouri and raised in the nearby town of Wright City. In 2003, he earned a B.A. in English from Missouri Baptist University. Unsure of what direction he wished to take in life, he moved to Santa Fe, New Mexico, where he completed an M.A. in Liberal Arts from St. John's College in 2007. Deciding to pursue an academic career in English, he returned to his home state of Missouri and earned an M.A. in English from the University of Missouri-Saint Louis in 2011. Desiring to follow in the footsteps of J.R.R. Tolkien, he earned his Ph.D. at the University of Missouri in 2017, with a focus on Anglo-Saxon literature and historical linguistics, along with a graduate minor in medieval studies. As a graduate instructor at the University of Missouri, he had the opportunity to teach a wide variety of courses in writing and literature, and made many friends from his colleagues and students. He has presented on the subject of kingship at several conferences, and has a forthcoming book chapter. In August 2017, he will begin a new faculty position at Indian River State College in Fort Pierce, Florida. 